\author{
Universidade de São Paulo \\ Faculdade de Filosofia, Letras e Ciências Humanas
}

DARCY ATTANASIO T. RAMOS

Uma leitura poético-filosófica de Marinheiro de primeira viagem,

de Osman Lins

São Paulo

2007 
Darcy Attanasio T. Ramos

Uma leitura poético-filosófica de Marinheiro de primeira viagem, de Osman Lins

Dissertação apresentada ao Departamento de Teoria Literária e Literatura Comparada da Faculdade de Filosofia, Letras e Ciências Humanas da Universidade de São Paulo, para a obtenção do título de Mestre em Letras.

Orientadora: Profa. Dra. Aurora Fornoni Bernardini. "de acordo"

São Paulo 
Darcy Attanasio T. Ramos

\section{Uma leitura poético-filosófica de Marinheiro de primeira viagem, de Osman Lins}

Dissertação apresentada ao Departamento de Teoria Literária e Literatura Comparada da Faculdade de Filosofia, Letras e Ciências Humanas da Universidade de São Paulo, para a obtenção do título de Mestre em Letras.

Data da defesa e aprovação: 25/06/2006

Banca Examinadora:

Orientadora: Profa. Dra. Aurora Fornoni Bernardini.

(De acordo)

Profa. Dra. Sandra Margarida Nitrini

Prof. Dr. Ricardo Iannace 
Ao Felipe, à Sophia, ao João e a quem mais vier...

Que eles descubram: que a realidade é quimera e o sonho, realidade. 


\section{Dedicatória}

Ao meu pai Floriano(in memoriam) e minha mãe Deolinda, origem de tudo

Ao Arsilio e aos filhos: Ricardo (Letícia), Fernanda (Sebá), Andrea (Edy) e Ana Carolina.

À minha irmã Dayze

Aos meus irmãos Luiz Fernando e Antonio Sergio (in memoriam)

Aos sobrinhos: Pedro, Mariana e Maria Júlia 


\section{Agradecimentos}

À minha orientadora, Profa. Dra. Aurora Fornoni Bernardini, com quem aprendi muito durante o meu mestrado. $\mathrm{O}$ meu agradecimento especial.

À Profa. Dra. Sandra M. Nitrini, pela oportunidade, quando eu procurava atingir meus objetivos e por ter me apresentado Osman Lins.

À Profa. Dra. Celeste, pela sua sensibilidade, atenciosa leitura e sugestões ao meu trabalho de qualificação.

Às "meninas das Letras", Beth e Jucimara, o meu agradecimento especial por todo o apoio e amizade ao longo dos nossos encontros de estudo, leituras e oportunas sugestões.

À Regina Célia B. Schmidt, minha amiga de tantos anos e de tantas leituras.

Ao Luiz de Mattos Alves, secretário do Departamento de Teoria Literária e Literatura Comparada da USP, pela competência e boa vontade. 
“Ontem, treze anos depois de sua morte, voltei a me encontrar com Osman Lins.

O encontro foi no porão de um antigo convento, sob cujo teto baixo ele encenava a primeira peça do seu Teatro do Infinito.

A peça, Vitória da dignidade sobre a violência, não tinha palavras: ele já não precisava delas.

Tampouco disse coisa alguma quando o fui cumprimentar. Mas o seu sorriso era tão luminoso que eu acordei."

(José Paulo Paes, “Reencontro”. In: Prosas seguidas de Odes mínimas.

SãoPaulo: Companhia das Letras, 2002, p. 43) 


\section{Resumo}

Esta dissertação tem por objetivo realizar uma leitura poético-filosófica do livro Marinheiro de primeira viagem, de Osman Lins, que se destaca por seu experimentalismo literário e por inovar o gênero "literatura de viagem". Embora seja um livro elaborado com base na viagem que seu autor fez à Europa, onde ficou seis meses, em 1961, ele não oferece a seus relatos as características que se costuma imprimir a esse gênero tradicional, em que o autor revela suas impressões e faz descrições das experiências vividas. Ao registrar suas memórias, ele cria uma estética literária inovadora por sua narrativa insubmissa, não-linear, marcadamente fragmentada, mas poética.

Nos registros, o diálogo intertextual com a tradição cultural é intenso, e destacaremos esse intercâmbio como memória que a literatura tem dela mesma. Nessa relação entre textos, ganha relevo o mítico Orfeu e sua amada Eurídice, que potencializam a poética do livro e congregam o leitor ao texto para uma leitura hermenêutica com base na estética da recepção.

Quanto ao aspecto filosófico do trabalho, encontramos apoio nas idéias hermenêuticoontológicas do filósofo Martin Heidegger e sua meditação sobre a obra de arte e a poesia, que contribuem para uma reflexão acerca do evento poético que unifica os fragmentos em Marinheiro de primeira viagem.

Palavras-chave: Osman Lins, narrativa, viagem, Orfeu, poética. 


\section{Abstract}

The purpose of this work is to do a poetic-philosophical reading of the Osman Lins book Marinheiro de primeira viagem, which is distinguished by its literary experimentalism, and its innovation in the "travel narrative". In spite of the fact that the author created this book based on a six month trip in Europe, in 1961, he didn't give it the characteristics normally founded in these traditional works which mean: impressions and descriptions of lived experiences. When he writes about his memoirs, he creates a new literary esthetics with a revolutionary narrative totally fragmentary and poetic.

In the author's notes the intertextual dialogue with cultural tradition is so intensive, that we will stress the value of this interchange as literature memoirs. In this relation between the texts, we will also stress the mythical Orpheus and his beloved Eurydice which increase the poetic in the book and gather the reader with the text for a hermeneutic reading based on the esthetics of the reception.

As for the philosophical aspect of this work, we have founded our choices on the philosopher Martin Heidegger hermeneutic-ontological ideas and his meditation on the works of art and the poetry, which contribute to a reflection about the poetic event which unifies the fragments in Marinheiro de primeira viagem.

Key words: Osman Lins, narrative, travel, Orpheus, poetic. 


\section{Résumé}

Ce mémoire a pour but de réaliser une lecture poétique-philosophique du livre Marinheiro de primeira viagem, d'Osman Lins, qui se distingue par son expérimentalisme littéraire et pour innover le genre "récit de voyage".

Quoiqu'il s'agisse d'un livre élaboré ayant pour base le voyage que son auteur a fait en Europe, où il est resté pour six mois, en 1961, il ne donne pas à ses narrations les caractéristiques qu'on imprime normalement à ce genre traditionnel où l'auteur révèle ses impressions et fait des descriptions des expériences vécues. Quand il enregistre ses mémoires, il crée une esthétique littéraire innovatrice par son récit insoumis, non-linéaire, complètement fragmentaire, mais poétique.

Dans les registres de l'auteur, le dialogue intertextuel avec la tradition culturelle est intensif donc, nous mettrons en valeur cette échange comme mémoire que la littérature a d'elle même. Dans cette relation entre les textes, gagnent relief le mythique Orphée et sa bien aimée Eurydice qui potentialisent la poétique du livre et rassemblent le lecteur au texte pour une lecture herméneutique en nous basant sur l'esthétique de la réception.

Quant à l'aspect philosophique $\mathrm{du}$ travail, nous avons l'appui des idées herméneutiques-ontologiques du philosophe Martin Heidegger et sa méditation sur l'œuvre d'art et la poésie, qui contribuent à une refléxion à propos de l'évévement poétique qui unifie les fragments dans Marinheiro de primeira viagem.

Mots-clés: Osman Lins, récit, voyage, Orphée, poétique. 


\section{SUMÁRIO}

Introdução..........................................................................

Capítulo I. Da Gênese à fatura de Marinheiro de primeira viagem................................................................................................

I.1. Ambiência do autor:Quadro dos primeiros anos...............................

I.1.1 Viagens, narrativas e as primeiras composições........................ $\quad \mathbf{2 0}$

I.1.2 Cálculos e esquemas.......................................... $\quad 22$

I.2. A viagem para Recife..............................................................

I.3. O projeto da viagem à Europa..................................................... $\quad 26$

I.3.1 A viagem de navio................................................................. $\quad 3$

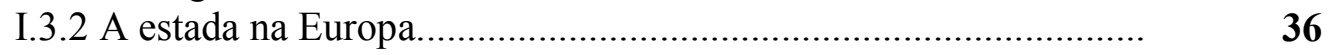

I.4. Escrever e esquecer.............................................................. $\quad 40$

I.5. Um projeto gráfico de Marinheiro de primeira viagem.................. 44

Capítulo II. Um olhar poético sobre Marinheiro de primeira viagem....... $\quad 55$

II.1. Como o autor gostaria que seu livro fosse lido............................. $\mathbf{5 5}$

II.2. O diálogo viagem-arte........................................................... $\quad \mathbf{2 8}$

II.3. Intertextualidade e memória em Marinheiro de primeira viagem $\quad \mathbf{8 3}$

II.3.1 Referências nominais ao mito do lendário Orfeu em Marinheiro

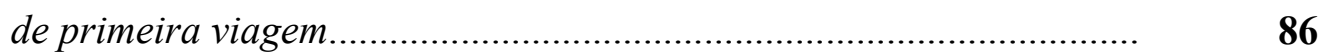

II.4. O mito grego de Orfeu.............................................................. $\quad 88$

II.4.1 A recepção e o efeito do mito de Orfeu em Marinheiro de primeira viagem........................................................................... 91

II.5. O papel da memória em Marinheiro de primeira viagem.............. 95

II.6. A partida e a despedida do Anti-Orfeu............................................ 99

Capítulo III. Poesia e pensamento em Marinheiro de primeira viagem.... 102

III.1. Filosofia e literatura: Uma relação intercomunicante.................... 102

III.2. Uma breve incursão no pensamento de Heidegger........................ 105

III.3. Uma leitura poético-filosófica de Marinheiro de primeira viagem

Considerações Finais............................................................................. 118

Referências Bibliográficas.................................................................... 119

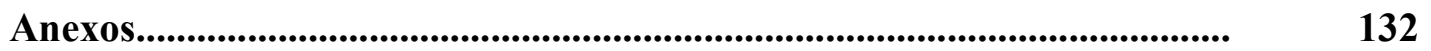




\title{
INTRODUÇÃO
}

\author{
Eles não sabem que o sonho \\ é uma constante da vida \\ tão concreta e definida \\ como outra coisa qualquer, \\ como esta pedra cinzenta \\ em que me sento e descanso, \\ como este ribeiro manso \\ em serenos sobressaltos, \\ como estes pinheiros altos \\ que em verde e oiro se agitam, \\ como estas aves que gritam \\ em bebedeiras de azul.
}

(António Gedeão, “Pedra filosofal”. In: Movimento perpétuo, 1956)

Primeiramente, é preciso que consideremos a necessidade de expressar a opção por trabalhar com uma obra do pernambucano Osman Lins (1924-78), justificando tal escolha e os caminhos que influenciaram o trabalho. No que concerne ao âmbito da pesquisa acadêmica e, portanto, como relevância intelectual da escolha, é possível destacar:

- a atualidade de sua obra, embora Osman Lins sempre tenha tido o cuidado de afirmar que escrevia para o seu momento;

- seus experimentalismos literários que redundaram em inovações, em particular, no gênero "literatura de viagem", com seu livro Marinheiro de primeira viagem, que será objeto específico de nosso estudo, embora não seja nossa proposta explorar de modo extensivo e aprofundado esse tipo de literatura;

- a inquietação em face de suas produções que abarca o leitor e o convida a um exame de sua linguagem, a desvendar algo que permita penetrar em seu universo criativo, difícil de ser classificado, devido a sua impertinência e, por isso mesmo, à inexistência de um único tópos que o defina. 
No que tange ao aspecto subjetivo da predileção, destacamos que estávamos em busca de um autor com o qual nos identificássemos e que nos permitisse trabalhar uma das vertentes do pensamento contemporâneo, que é o da aproximação entre literatura e filosofia, na linha da filosofia de Martin Heidegger.

Ao nos acercarmos mais de suas produções - as obras narrativas, os ensaios, as peças teatrais -, pudemos aproximar-nos de sua criação estética e de sua concepção de mundo. Os textos osmanianos conquistaram-nos, principalmente Marinheiro de primeira viagem, e concluímos que havíamos encontrado o autor e a obra com que nos identificávamos e que forneceriam os requisitos para a elaboração da pesquisa almejada.

Em Marinheiro de primeira viagem (1963), tivemos a oportunidade de apreciar um tipo de linguagem desafiadora e insubmissa. E, por uma questão de empatia, a nossa decisão foi por um estudo mais pormenorizado desse livro, trabalho que é um marco na produção literária do autor, porque, além de registrar as experiências da primeira viagem à Europa, que foi fundamental em sua formação como escritor, inaugura seu modo fragmentado e descentrado de narrar. Apreciar a originalidade de uma nova estética impulsionou-nos a penetrar nesse tipo específico de narrativa não-linear.

Procurando tornar-nos próximos à ambiência inspiradora do livro, decidimos fazer uma viagem à Europa. Elaboramos um plano cultural de visita intensa a Paris e a várias cidades européias e, por quase três meses, procuramos fazer um percurso muito semelhante daquele realizado por Osman Lins em 1961, que se tornou tema do livro escolhido para análise, reunindo assim condições mais propícias para comentar com mais conhecimento de causa alguns dos textos do autor.

A partir das experiências da viagem, das leituras e releituras da produção de Osman e de sua fortuna crítica, conjugamos as nossas motivações pessoais às acadêmicas, pois todo esse conteúdo sugeriu-nos indagações, das quais uma pertence ao campo da literatura e outra, ao da filosofia, que esquematizamos da seguinte forma:

- Qual a expressividade do diálogo intertextual com o mito grego do cantor-poeta Orfeu nos procedimentos compositivos do livro?

- Quais as implicações filosóficas que o livro suscita?

Para desenvolver essas duas linhas de pesquisa, dividimos nosso trabalho em três capítulos: no primeiro, cujo foco será o descritivo-memorial, faremos uma incursão biográfica e uma apresentação do livro de Osman Lins (Marinheiro de primeira viagem). Mapeamos sua 
gênese e buscamos, desde a sua infância, nas ocorrências cotidianas, os eventos em que se desencadeiam as primeiras motivações, como o gosto pelas narrativas e pelas viagens e a convivência com os traçados geométricos, na alfaiataria de seu pai; até a sua "fatura". Destacamos o esforço de Osman Lins em conseguir apoio financeiro que viabilizasse sua permanência, principalmente em Paris, para realizar seu intento e mostrar como a experiência possibilitou-lhe penetrar num universo cultural que ele considerava necessário à sua formação enquanto escritor. Acompanhamos a viagem em si, desde sua partida do Brasil e a chegada à França, a estada em Paris, a visita a outras cidades européias; seu retorno, e a elaboração de Marinheiro de primeira viagem. Anexamos no apêndice tudo o que pudemos recolher que estivesse relacionado ao livro, desde as cartas que Osman Lins endereçou aos órgãos competentes na fase em que ele esforçava-se para pleitear uma bolsa de estudos na França; a entrevista a Esdras do Nascimento na Tribuna da Imprensa, jornal do Rio de Janeiro, de 26/08/1963, que concentra informações quantitativas e qualitativas da viagem; acrescentamos também parte da entrevista concedida a Edna Savaget, "Os deuses nada arriscam”, publicada no Jornal do Commercio, de Recife, de 29/12/1963; além de várias críticas e comentários, que foram publicados em diferentes jornais, como as de Barbosa de Rolme, Geir Campos; os comentários que vieram a público no jornal Correio da Manhã; os de Massaud Moisés, Nogueira Moutinho, Ricardo Ramos, Virgínius da Gama e Mello.

Para cumprir essa parte do trabalho, recorremos a consultas aos arquivos do Instituto de Estudos Brasileiros da Universidade de São Paulo (IEB-USP), que concentra grande parte das informações sobre Osman Lins e seus manuscritos do diário de bordo.

Com esse encaminhamento inicial, nossa intenção foi coletar o maior número possível de informações sobre Marinheiro de primeira viagem, para que o trabalho a ser desenvolvido encontrasse respaldo nessas informações, já que a fortuna crítica desse livro é ainda bastante reduzida.

Expusemos em nossa concepção pessoal de Marinheiro de primeira viagem, os diagramas que elaboramos, em que destacamos a figura geométrica do círculo, a qual esboça a "forma" em que o livro está inscrito. Essa forma, de alcance mítico, envolve todo o conteúdo da composição, encerrando nesse espaço circular todas as lembranças da viagem. Os diagramas foram realizados com base nos vínculos existentes entre os próprios fragmentos e em informações e comentários fornecidos pelo próprio Osman Lins, que sentia fascinação por algumas figuras geométricas (LINS, 1979, p. 157). Ao montar os esquemas, a sensação que nós tínhamos era a de estar cumprindo um procedimento de organização: marca da maneira de Osman Lins trabalhar. 
No segundo capítulo foi dado destaque ao mito grego de Orfeu e a seus temas, salientando sua presença intertextual e sua ressonância na interpretação do livro em questão. Meletínski (1987, p. 2) afirma que há na literatura do século XX uma nova valorização dos mitos antigos, como princípio eternamente vivo que encontra na filosofia de Nietzsche e Bergson, na psicanálise de Freud e na arte musical de Wagner seu renascimento apologético e procuraramos mostrar que Osman Lins não ficou indiferente a esse gosto. Pusemos em evidência a importância desse renascimento, principalmente a que foi dada ao poeta lendário Orfeu, na literatura, no cinema e no teatro à época de Osman Lins, especificamente desde o início do século XX até 1963 a data de lançamento de Marinheiro de primeira viagem.

Será dada ênfase ao diálogo textual a que Osman Lins recorre para relatar os eventos da viagem, e, para buscar apoio teórico sobre a intertextualidade, faremos um percurso desde Mikhail Bakhtin, Julia Kristeva até Tiphaine Samoyault, cujo trabalho desenvolvido em L'intertextualité: Mémoire de la littérature (2001) se nos afigura como uma reflexão essencial sobre o tema, em que a autora reflete sobre a dimensão da memória que a literatura tem dela mesma e que "propõe uma poética dos textos em movimento". Embora, o diálogo intertextual em Marinheiro de primeira viagem esteja muito presente, não é nossa proposta operacionalizar, nem realizar uma análise classificatória da prática intertextual. E, com o suporte teórico apontado acima, pudemos desenvolver o diálogo viagem/arte em que a intertextualidade está tão presente ao longo das lembranças que Osman Lins registra.

Assim como Goethe, que, para escrever sobre a sua própria vida em Poesia e verdade, só podia encontrá-la "dando aos fatos isolados e dispersos de sua vida uma forma poética, ou seja, simbólica” (CASSIRER, 2005, p. 89), também Osman Lins lança mão de recursos poéticos da tradição, para simbolizar e conseguir traduzir sua própria vivência da viagem. $O$ respaldo teórico da estética da recepção ofereceu o suporte interpretativo a essa etapa da dissertação, na medida em que o texto literário apresenta-se como um ponto de encontro e de relevância entre o leitor e o escritor. Para essa proposta foram acolhidas as idéia de Hans Robert Jauss e Wolfgang Iser.

No Capítulo III, faremos uma leitura de Marinheiro de primeira viagem, em que conjugaremos os estudos realizados no campo literário e filosófico. Vale destacar que filosofia e literatura envolvem territórios que se mesclam, mas não se neutralizam. O jogo literário em Marinheiro de primeira viagem é revelador de sentido, que se mostra na reflexão filosófica. Para tanto, valendo-nos, em particular, da fenomenologia e da hermenêutica de Martin Heidegger, procederemos a uma reflexão quanto às implicações recíprocas existentes, o que nos permitiu, com isso, responder às questões que motivaram essa pesquisa. 
Embora a proposta do trabalho não seja realizar uma analítica existencial de Marinheiro de primeira viagem, faremos uma breve incursão no pensamento de Heidegger tal como se configura em Ser e tempo (1927). A pertinência revela-se em função de essa obra consistir em um trabalho fundamental que abriga as reflexões do filósofo sobre o sentido do Ser. Ele propõe-se a determinar o ser do ente que todo homem é, e desenvolve o conceito de Dasein, em que sobressai a valorização da condição humana, cujo foco principal é o ser de carne e osso que existe, que tem uma história, que "medita sobre a sensação de estar vivo", como afirma Terry Eagleton (2003, p. 85), mostrando a não possibilidade de captar o ser, fora do sendo. Além disso, permite-nos reflexões como a que se faz em torno do ser-no-mundo, aquele sujeito que está no mundo, tem uma história e só existe a partir de "dentro de uma realidade que nunca podemos objetivar plenamente, que abarca tanto 'sujeito' quanto 'objeto', que é inesgotável em seus significados e que nos gera tanto quanto nós a geramos" (EAGLETON, 2003, p. 86).

O sentimento de angústia integra a existência que se pode caracterizar pela inautenticidade e a autenticidade. Segundo Heidegger, existir é dialogar com o mundo, é já estar de posse de um pré-entendimento que faz parte da estrutura da existência humana, que tem a capacidade de projetar-se para além de si mesmo, e envolver-se com novas possibilidades, independentemente da iminência de ser um ser-para-a-morte. Heidegger vai definir o ser humano como algo constituído pela história, o que equivale a dizer constituído pela temporalidade, sua estrutura mais íntima.

$\mathrm{O}$ desejo de totalidade do viajante, em Marinheiro de primeira viagem, destaca-se pelo voltar-se para fora, em busca de outro horizonte cultural, mas que, ao mesmo tempo, foi uma busca dentro de si. O esforço de desocultamento e de aproximação com a própria história, cujos laços estavam lá na Europa, uma espécie de retirada do "véu de Maia", para que ele pudesse refazer laços, numa pré-compreensão do mundo em que ele já se encontrava.

O "viajante" vincula-se ao passado, se reconhece "ligado aos homens de há 700 anos", como ele bem confirma no fragmento "Saint-Étienne" (p. 11-2). O tempo, a história, de que ele se aproxima é uma tomada de consciência de si mesmo, é um apossar-se in loco, pois as coisas revelam-se em seu contexto. A busca do sentido das coisas é a mola que aciona e conduz a viagem do autor. Pela composição intertextual dos fragmentos, podemos de imediato perceber que o mergulho no continente europeu não assumiu o caráter de mera visita turística ou de curiosidade banal por tudo o que estava a seu redor e pelas possibilidades que ele mesmo buscou, dando-se nele um enraizamento tal, que ele pode afirmar, no mesmo fragmento mencionado anteriormente: "Que nostalgia temos nós de um mundo que, segundo 
as aparências, não existe - e que, mesmo se com ele nos defrontamos pela primeira vez, levanta em nós uma dupla alegria, a de descobrir, a de reencontrar?"

Em $A$ origem da obra de arte, Heidegger faz uma reflexão sobre a natureza da obra de arte cuja descoberta "vai a par com a dos poetas" (BOUTOT, 1993, p. 109), produzindo uma análise existencial da obra artística, seja ela qual for, uma escultura, uma pintura, e também o que é produzido na literatura, pois o que nela ocorre é a obra assumir o vigor de tornar visível o mundo que aí se desoculta. A questão da palavra e da linguagem são pontos centrais das reflexões de Heidegger, é o que faz o mundo ser. Ela é condição de existência do próprio mundo e a morada do ser, portanto. Tudo isso nos é manifestado não na contemplação, mas no fazer, cuja fenomenologia mostra-se na arte. A verdade do mundo manifesta-se na arte, na linguagem, ela acontece na interpretação literária, e, por isso, devemos nos deixar interrogar pelo texto (EAGLETON, 2003, p. 89), não como o lugar em que fazemos alguma coisa, para depois conhecê-la, "mas [como] algo que devemos deixar que aconteça". É a partir dessas questões postas pelo teórico alemão que procuraremos aproximar-nos para realizar uma leitura filosófica de Marinheiro de primeira viagem. 


\section{CAPÍTULO I}

\section{DA GÊNESE À FATURA DE MARINHEIRO DE PRIMEIRA VIAGEM}

[...] eles não sabem que o sonho é vinho, é espuma, é fermento, bichinho álacre e sedento, de focinho pontiagudo, que fossa através de tudo num perpétuo movimento.

(António Gedeão, “Pedra filosofal”. In: Movimento perpétuo, 1956)

\section{I.1. Ambiência do autor: Quadro dos primeiros anos}

O objetivo central desta dissertação não é escrever uma biografia de Osman Lins, mas nessa primeira etapa do trabalho julgamos pertinente salientar alguns episódios de sua vida, pelo fato de Marinheiro de primeira viagem ter a marca de seus anseios pessoais, sua visão de mundo e sua história. Captar os vínculos desse livro com sua experiência singular é encontrar a raiz de seu gosto pelas narrativas, pelas viagens, pela organização e pelos esquemas, é testemunhar as "transferências catárticas da vida do autor para a sua obra" (IGEL, 1988, p. 7), é apreciar o escritor mergulhado em seu mundo e superando-o pela arte.

Ao adotar inicialmente a linha memorial, não tivemos a intenção de contribuir para ampliar o conhecimento de sua vida particular ou de idealizar fatos, mas sim a de enriquecer a leitura do livro, visto que o estudo de determinados eventos em destaque pode motivar, ampliar e solidificar o trabalho crítico.

Não podemos ficar indiferentes à afirmação de um autor segundo a qual, em sua obra, há continuidade e metamorfoses, e muitos motivos presentes em livros mais novos "já aparecem, embrionários, nos livros anteriores" (LINS, 1979, p. 266). Por que não dizer, então, que eles nascem do cotidiano de sua vida?

Segundo Osman Lins, nunca "se dissocia o romancista, em seus livros, do vivido" (idem, 1969, p. 200), havendo harmonia entre "o ficcionista e a realidade". Os acontecimentos 
da vida do escritor estão presentes no ato de escrever. Mesmo que sua imaginação aparente certa capacidade autônoma, há a inoculação de sua própria experiência no texto, patenteando a interação de sua vida e sua obra. Como ele assevera, "cada livro publicado representa a súmula de nossa vida. Nossa existência inteira converge para cada novo livro que entregamos ao leitor" (idem, 1979, p. 133).

Assim, em vista dessa confluência de elementos biográficos em sua escrita, com seu pleno reconhecimento do fato, julgamos importante destacar alguns eventos, dentro do objetivo claro de nos aproximar de seu ideário criador.

Osman Lins nasceu e foi criado na cidade de Vitória de Santo Antão, no estado de Pernambuco. Lá não havia biblioteca, uma livraria razoável que fosse, universidade, ou seja, era difícil encontrar algum espaço em que pudesse dar vazão a seus anseios de ordem intelectual, e que se manifestaram desde muito cedo.

A única novidade que lá chegava eram os filmes alemães e franceses, além dos que vinham dos Estados Unidos. Eram obras, muitas vezes, carregadas de mensagens ideológicas, o que na época lhe escapava. O cinema, com toda a agitação que trazia para a vida da cidade, era, então, para ele, "uma porta de acesso ao mundo" (id., ibid., p. 103). O movimento social e cultural vinha também da igreja, com as missas de domingo e "as comemorações marianas, realizadas durante todo o mês de maio" (id., ibid., p. 101), assim como dos clubes esportivos, em que jogou futebol, marcados pelo abandono. Também contribuindo para o pouco de dinamismo que havia na cidade, essas associações promoviam algumas reuniões dançantes, além do baile anual de Carnaval. Fora isso, nada de extraordinário acontecia, "naquela cidade sem horizontes" (id., ibid, p. 103). Mas é justamente nessa primeira etapa de sua vida, desse mundo quase sem perspectivas futuras, que ele acumulou ampla temática vivencial e amalgamou-a, projetando-a em suas criações literárias.

Em função da morte prematura da mãe, que o deixou órfão aos 16 dias de nascimento, Osman Lins foi educado principalmente pela avó paterna, Joana Carolina, mas também por uma tia, a "mãe Laura", irmã de seu pai e casada com Antônio Figueiredo. Na ausência da mãe natural, ele acabou por receber uma dedicação extremada dessas duas mulheres, que preencheram sua infância de zelo e afeto, atenuando a "solidão e a estreiteza" (LINS, 1979, p. 189) de seus primeiros anos. As duas, com sua presença intensa, tiveram papel fundamental em sua vida. E ambas foram homenageadas em suas obras: a tia, "no relevo pessoal de Teresa de O fiel e a pedra (1961)", e a avó, que receberia “canonização literária" em Retábulo de Santa Joana Carolina $(1966 ; 1988$, p. 19). 
Maria da Paz de Mello Lins, a mãe falecida, viveu pouco, comenta ele, e "veio ao mundo, parece, com o único encargo de ser a minha mãe. Cumprida essa tarefa, morreu, um ano depois de casada. Coisa estúpida. [...] Morreu aquela garota para que eu nascesse. Não podia fazer da minha vida uma trouxa, um papel servido, jogá-la por aí" (id., ibid., p. 188). O compromisso assumido com a consciência da perda materna imprimiu-lhe o encargo de conduzir a própria vida com certa maestria e muita responsabilidade, atitude essa que ele transporia para suas obras, no rigor narrativo e na busca pela perfeição da forma.

Segundo versão consensual, Maria da Paz havia escrito um número considerável de poemas, em torno de 200, quando era uma adolescente, que, no entanto, teriam sido destruídos junto com outros pertences logo após sua morte. Dela não restou nenhuma foto sequer para aliviar em nosso autor o sofrimento da perda (MOURA, 2003, p. 20). Mas a obsessão por encontrar em outros lugares seu retrato perseguiu-o e acabou por entrar em seus livros. É o que vemos na trajetória de Abel, personagem principal de Avalovara (1973), que "passa a vida toda procurando" (LINS, 1979, p. 174). Segundo Osman, ele ficou com a impressão de que, atrás de si, havia uma "espécie de claro" que chega a configurar a sua vida como escritor, "pois parece que o trabalho do escritor, metaforicamente, seria construir com a imaginação um rosto que não existe” (LINS, 1979, p. 211). A busca desse rosto, que praticamente não chegou até ele, a procura por essa forma desconhecida, traduziu-se no esmero posto no processo de encontrar uma estrutura adequada, em que suas narrativas se acomodassem. Poderíamos dizer que esta foi também uma maneira de tentar refazer os laços rompidos com a mãe.

Com apenas 8 anos de idade, ele escreveu um poema, "Beduíno regenerado pela Lua", que foi mal recebido pela família, pois os versos não obedeciam aos padrões métricos e rítmicos. Apesar da decepção que isso lhe causou, porém, Osman Lins sonhou desde a infância ${ }^{1}$ seguir o caminho literário. Passada essa decepção, tempos depois ele se pergunta: "Que significava esse tema estranho? Como se eu soubesse que a poesia salva o homem" (id., ibid., p. 168). Salvação que ele procurou na palavra e pela palavra, ao longo de toda a sua vida, no ofício de quem sabe manipular "umas palavras contra outras, exercer sobre elas uma espécie de atrito, fustigando-as, até que elas desprendam chispas: até que saltem, dentre as palavras, demônios inesperados" (idem, 1973, p. 211).

\footnotetext{
${ }^{1}$ Informação encontrada em manuscrito do autor, pesquisado no IEB-USP. Caixa 2: Grupo Magistério. Evento: Programa, planos de cursos e artigos publicados durante as atividades acadêmicas. Plano de aula: A criação literária. Pasta 2.
} 


\section{I.1.1 Viagens, narrativas e as primeiras composições}

Uma infância solitária "sem riqueza e sem irmãos", até os 12 anos, propiciou ao menino "muito cedo a viver para dentro e a inventar fantasmas" (idem, 1979, p. 188). A pessoa que amenizou sua solidão foi o tio Antônio Figueiredo, marido de "mãe Laura", que também aparece em uma de suas obras. Osman Lins comenta que ele foi um homem excepcional: era "tudo o que pode sonhar o coração de um menino. Lá está ele, transformado, também em O fiel e a pedra (de 1961), com o nome de Bernardo Vieira Cedro, vivendo aventuras muito semelhantes a algumas que enfrentou realmente" (id., ibid., p. 189). Osman Lins lembra as muitas viagens que ele fazia e as narrativas do retorno, que lhe alegraram a infância e que ativaram sua imaginação. Recorda que o tio estava "sempre viajando pelo interior do Nordeste, tanto para comprar ouro como para tanger bois ou burros, pois, como dizia, "se parasse, estava perdido"”. "Foi ele o meu primeiro livro, meu iniciador na arte de narrar" (id., ibid., p. 189). Talvez o tio nunca tenha lido um livro, segundo comentário do próprio Osman Lins, mas contava histórias maravilhosas, que encantavam o sobrinho, o qual o ouvia interessado noite adentro a narrar suas aventuras. "Foi a ele, e não a um escritor, que procurei imitar, quando [...] esbocei as primeiras narrativas", revela o escritor (LINS, 1979, p. 189).

Para ele, o tio teve a mesma importância que a velha Teotônia, "a primeira influência literária de José Lins do Rego. Com a diferença de que as suas histórias não falavam de princesas ou dos Dozes Pares de França, mas dos homens que ele conhecia e do chão onde pisava" (id., ibid., p. 189).

Não eram somente os casos contados pelo tio que o encantavam, mas também seu caráter. Osman Lins, já escritor consagrado, refere-se a ele como um daqueles homens difíceis de se encontrar no mundo. Uma de suas características era ser "um mão-aberta, um homem leal, confiante, alegre e nunca soube [...] que diabo de coisa era o medo. A não ser, talvez, quando adoeceu para morrer, pois amava de verdade a vida”. E acrescenta ainda que ele tinha habilidades para consertar seus brinquedos, "mesmo quando pareciam irreparáveis, jogava pião, soltava papagaios, fazia anéis", pois, "além de outras coisas, era também ourives" (LINS, 1979, p. 189).

Apesar de ter influenciado a formação de seu caráter e de ser o grande responsável pela construção de seu imaginário narrativo, seu tio jamais seria capaz de estimulá-lo a escrever. Osman Lins lembra que aprendeu as primeiras letras em casa, e que a grande influência e o incentivo para a literatura vieram de seu antigo professor, o ex-seminarista José 
Aragão, de quem foi aluno durante alguns $\operatorname{anos}^{2}$, no Colégio Santo Antão, em sua cidade natal. Ele observa que o mestre "transferira para o ensino o sacerdócio e nunca limitou às aulas a sua pregação literária", afirmando que, em grande parte, a "decisão de entrar de corpo inteiro nas letras, de escrever alguns livros [...] deve-se ao seu encorajamento" (id., ibid., p. 189).

O antigo professor lembra que pegou o menino "apenas alfabetizado". "Eu puxei por ele o quanto podia, e ele correspondeu", afirma. Embora tenha reconhecido que Osman "foi um homem que se fez por si mesmo, porque encontrou no cultivo às letras seu modo de estar e de atuar no mundo" 3 , seu papel foi o de identificar o aluno como um vocacionado para a escrita e, por isso, procurou ajudá-lo e estimulá-lo ao máximo.

Foi no espaço da escola que Osman teve a oportunidade de desenvolver-se e despertar para a literatura. O professor Aragão conta que ele corrigia seus "poucos erros de português" e que, além disso, "publicava os trabalhos do jovem no periódico do colégio, chamado Estímulo ${ }^{4}$. Já nessa época ele participou de concursos promovidos pelo jornalzinho e chegou a ser premiado em alguns deles (MOURA, 2003, p. 23-4).

José Aragão, em discurso na Sociedade Artística Cultural Vitoriense, no Clube XVI, em 14 de agosto de 1960 (id., ibid., p. 23), ao lembrar seu antigo aluno, já famoso escritor, revive esse tempo:

\footnotetext{
O que percebo na formação dessa criança é que, no isolamento em que foi criada, entregue a si mesma, girando sempre em torno dos mesmos motivos, se haja tornado um introspectivo, vivendo mais da fantasia, do raciocínio para o mundo interior, o que, de certo, he haveria de aguçar qualidades inatas na percepção das coisas, na interpretação dos fatos, na apreciação das circunstâncias e dos segredos, os mais íntimos, da alma humana, enfim no exame anatômico da própria vida.
}

O antigo professor já reconhecia então uma tendência intimista no estilo do jovem estudante. Desde muito cedo, ele se revelara extremamente cuidadoso na escolha das palavras e com o que escrevia, fazendo e refazendo seu texto "até chegar à forma que lhe agradasse" (MOURA, 2003, p. 23): o futuro escritor já era um perfeccionista.

\footnotetext{
${ }^{2}$ O período que Osman Lins esteve sob a orientação de José Aragão foi de fevereiro de 1933 a novembro de 1940.

${ }^{3}$ Entrevista de José Aragão Bezerra Cavalcanti à jornalista Mona Lisa Dourado (1998, p. 16-7).

${ }^{4}$ Id., ibid.
} 


\section{I.1.2 Cálculos e esquemas}

A preocupação com a estética foi uma herança que Osman Lins recebeu, passível de ser transferida para suas obras. Teófanes da Costa Lins, seu pai, era alfaiate e, como tal, utilizava a fita métrica, as réguas retas e curvas, para medir e riscar, ao exercer sua "bonita profissão" (LINS, 1979, p. 117).

A convivência com a arte e o ofício dos alfaiates deixou impressões em seu espírito. $\mathrm{O}$ giz usado nos tecidos para fazer as marcações, delimitar as medidas e indicar o caminho que a agulha e a linha deveriam seguir, não foi esquecido: era "macio e brilhante, de variadas cores". Ele lembra "que passava horas acariciando com as pontas dos dedos os pedaços de giz, captando para sempre aquela sensação de maciez" (id., ibid., p. 117). Mesmo os alinhavos que seu pai realizava nas roupas, que indicavam os contornos a serem seguidos, para que nada saísse do previsto e do demarcado, deixaram-lhe recordações e influências.

Nada disso lhe passou despercebido. Os esquemas geométricos, base do traçado do desenho de um terno masculino, mais pareciam cartas astrais, cuja habilidade na elaboração era exigência a ser atendida por todo bom alfaiate, principalmente se adotasse o estilo artesanal da Alfaiataria Lins. Osman lembra os moldes dos ternos que o pai traçava enquanto profissional que adotou o corte clássico, "sem exageros decorrentes das modas" (id., ibid., p. 117), num texto comemorativo ao Dia do Alfaiate, 6 de setembro ${ }^{5}$. Ele diz ver relações entre o trabalho do alfaiate e o do escritor, pois ambos precisam, para exercer seu ofício, de uma marca pessoal (id., ibid., p. 115).

Seu pai não cedeu aos modismos, seja das roupas "excessivamente largas ou demasiado estreitas", mesmo que isso lhe tenha causado perda de clientela. A fidelidade ao corte clássico, em que as proporções são respeitadas, era para ele motivo de orgulho, "de seriedade e respeito à profissão", traço esse que também o filho imprimiu em suas criações literárias, ao não fazer concessões em hipótese alguma.

No texto em homenagem aos alfaiates, ele lembra o pai em seu ambiente de trabalho acertando o tecido de "brim estendido cuidadosamente na mesa, cantando com a boca fechada, traçando, com o auxílio de seus instrumentos, uma geometria cuidadosa". Aquelas imagens faziam-no recordar desenhos de seus livros escolares, que mostravam "os meridianos, o Zodíaco, as constelações" (id., ibid., p. 117).

\footnotetext{
${ }^{5}$ Osman Lins, "Um dia que se despede do calendário", 04/09/1976, in Evangelho na taba: Outros problemas inculturais brasileiros.
} 
Cálculo, estruturação e medida são as práticas que marcarão a arte do pai artesão e o artesanato literário do filho escritor, o qual segue essa mesma vertente, embora jamais se tenha extremado "a ponto de perder o sentido do humano demasiado humano de que nunca se afastou" (HELIO, 1998, p. 2).

Quando menino, Osman Lins estava acostumado com as formas geométricas e com os cálculos que seu ambiente familiar lhe proporcionava, depois de adulto é ele mesmo quem declara: "Pitágoras e a alquimia não são estranhos à minha atração pelas figuras geométricas" (LINS, 1979, p. 179). Talvez por isso, e pela indicação do escritor José Geraldo Vieira, ele tenha sido leitor dos ensaios de Matila C. Ghyka ${ }^{6}$ (id., ibid., p. 179), que contribuíram para aumentar seu interesse por números e proporções presentes na natureza e cujos conhecimentos acabaram por ser projetados na organização de seu universo literário. Em Marinheiro de primeira viagem, podemos observar esse interesse por organizações geométricas, pela forma circular que sustenta e organiza os fragmentos, tema que apresentaremos no Capítulo II.

\section{I.2. A viagem para Recife}

Diante do fraco quadro de oportunidades que oferecia sua cidade natal, só lhe restava viajar, pois seu espírito inquiridor e determinado não se contentava com nenhum tipo de cerceamento de ordem geográfica ou intelectual. Impulsionado pelo espírito de recherche, tinha anseios de "ganhar" o mundo, o que ocorreu pela primeira vez quando contava 16 anos de idade, em 1941.

Em seu conto "A partida" ${ }^{7}$, que é autobiográfico ${ }^{8}$, é possível acompanhar os últimos momentos “da despedida de sua coexistência com 'Mãe Noca"” (IGEL, 1988, p. 27), que encheu sua infância e parte da adolescência de extremos cuidados:

\footnotetext{
${ }^{6} \mathrm{O}$ diplomata romeno Matila C. Ghyka escreveu Esthétique des proportions dans la nature et dans les arts (1927), Le nombre d'or (1931), Sortilège du verbe (1949). Nessas obras, ele aborda a "proporção áurea", ou "número de ouro", uma medida especial utilizada nas artes, que é também denominada "razão áurea", ou "divina proporção", e remontaria ao geômetra Euclides, na Grécia antiga (século III a.C.). Essa medida pode ser encontrada nas conchas, nas colméias, em algumas frutas, folhas, nos seres humanos etc. Pintores como Giotto, Rafael, Michelangelo e outros renascentistas recorreram amplamente a ela na organização de suas obras. $\mathrm{O}$ "número de ouro" ganhou uma aura mística, e sempre despertou grande curiosidade e fascínio em artistas, escritores e pesquisadores.

7 "A partida" in Os gestos (1957).

${ }^{8}$ Osman Lins deixa claramente expresso que o conto é autobiográfico. Informação encontrada em manuscrito do autor, pesquisado no IEB-USP. Caixa 2: Grupo Magistério. Evento: Programa, planos de cursos e artigos
} 


\begin{abstract}
Na véspera da viagem, enquanto eu a ajudava a arrumar as coisas na maleta, pensava que no dia seguinte estaria livre e imaginava o amplo mundo no qual iria desafogar-me: passeios, domingos sem missa, trabalho em vez de livros, mulheres nas praias, caras novas. Como tudo era fascinante! Que viesse logo. Que as horas corressem e eu me encontrasse imediatamente na posse de todos esses bens que me aguardavam. Que as horas voassem, voassem! (LINS, 1994, p. 33).
\end{abstract}

Com esse anseio, ele parte para a cidade de Recife a fim de estudar e trabalhar. Nos pertences, carregava seu primeiro pincel de barba e um ovo artificial, para consertar as meias que puíssem (idem, 1979, p. 188), além de dois contos: "Menino mau" e "Fantasmas". Em sua bagagem interior, muito afeto recebido por parte da família, as experiências das narrativas de viagens ouvidas do tio, a estética geométrica herdada da arte paterna, o incentivo do professor Aragão e a grande convicção de que se tornaria um escritor. Sobre essa determinação, Osman Lins afirmaria, algum tempo depois: "me alistei na literatura, fiz votos, assinei um pacto, jurei fidelidade, convertendo num projeto sem volta" (p. 190). Assim ele transformou a batalha com a palavra escrita em sua "própria razão de viver" (p. 135), sua salvação, seu esquadro e seu equilíbrio (p. 153).

Na nova cidade, ele é recebido pelo tio, Álvaro da Costa Lins, que o encaminha para seu primeiro emprego, como escriturário, no Ginásio de Recife, atual Colégio Padre Félix. Nesse período de adaptação do jovem ao novo ambiente, o tio Álvaro apresenta o sobrinho a dois escritores, Mário Sette e Mário Motta, que o ajudam a publicar os primeiros contos em um jornal da cidade. Pouco tempo depois (1943), ingressa no Banco do Brasil, por concurso, mas não abandona o compromisso de dedicar-se às letras. Este propósito foi se solidificando, porque para ele não havia nada que o motivasse mais ou que justificasse melhor sua passagem pelo mundo (id., ibid., p. 189-90).

Em 1944, ingressa na Faculdade de Ciências Econômicas. Neste mesmo ano faz também cursos de dramaturgia, mas precisou também exercer a atividade bancária, porque era o que lhe garantia a subsistência. Mas o trabalho no banco não lhe agradava, fazendo com que buscasse refúgio e compensação na carreira literária, que, aos poucos, foi construindo. Segundo ele, precisava ter "um pé na literatura e outro numa profissão qualquer"9.

publicados durante as atividades acadêmicas. Plano de aula: Relação de um ficcionista com seus personagens. Pasta 2.

9 Informação encontrada em trabalho datilografado do autor, pesquisado no IEB-USP. Caixa 2: Grupo Magistério. Evento: Programa, planos de cursos e artigos publicados durante as atividades acadêmicas. Plano de aula: Problemas e dilemas do escritor brasileiro. Pasta 2. 
Nesse período, ele escreve outros dois contos, "E onde os castelos?" e "Rei Mindinho", que por engano foram publicados na parte infantil do suplemento dominical do Jornal do Commercio. É que os títulos dos trabalhos sugeriam histórias infantis.

Depois dessa experiência, ele desiste, pelo menos por algum tempo, de publicar em jornais (LINS, 1979, p. 211) e passa a redigir um romance. Teve início um período de cinco anos em que escreveu muito, sem obter, segundo ele, "um só parágrafo aproveitável". Mas Osman Lins observa que isso significou uma vitória contra a dispersão muitas vezes provocada pela juventude. Em todo caso, "foram cinco anos de convívio diário com as palavras" (id., ibid., p. 168), o que lhe proporcionou um bom exercício de escrita.

Após essa fase de relação crítica com as palavras, com o engano no jornal e o romance inaproveitável, ele foi percebendo que a "mão estava ficando mais firme". Como havia prometido escrever coisas leves, idealizou um livro de contos que viria a se tornar mais tarde Os gestos (1957). Aos poucos, sem que o próprio Osman Lins tivesse a exata percepção do que ocorria, um dos contos foi tomando proporções tão amplas, que se transformou em romance: $O$ visitante, premiado no Concurso Fábio Prado (1954). Foi seu livro de estréia. Com essa distinção, seu nome recebeu ampla divulgação em todo o Brasil, como o "novo, simples e cristalino escritor do Nordeste" (IGEL, 1988, p. 44).

Cada vez mais envolvido com as letras, ele se inscreve em concursos literários, sendo premiado algumas vezes. Atua também na redação da revista Memorandum, órgão da Associação Atlética Banco do Brasil (AABB). Está sempre empenhado no próprio aprimoramento como ficcionista, e é esta a razão pela qual participa "de certames literários em diversos pontos do país" (id., ibid., p. 41). Escreve regularmente para o Suplemento Literário do Diário de Pernambuco e trabalha na direção e produção de programas radiofônicos de cunho cultural da Rádio Jornal do Commercio, de Recife. Em função disso, adapta obras da literatura para o rádio. Além disso, escreve crônicas diárias, o que é um modo de fazer parte e manter-se próximo dos meios literários.

Osman Lins passa também a ser solicitado "para dar palestras, entrevistas e marcar sua presença de prestígio em número incontável de reuniões promovidas por colegas literatos, jornalistas, livreiros e estudantes" (IGEL, 1988, p. 46). Inicia então suas primeiras colaborações críticas para o jornal $O$ Estado de S. Paulo (1956). Nessa mesma época, é premiado pela publicação de Os gestos (1957), seu primeiro livro de contos.

Em 1957 sua peça teatral $O$ vale sem sol recebe destaque no Concurso Companhia Tônia-Celi-Autran, e ele publica em jornal algumas poesias. Em 1960, finaliza o curso de dramaturgia na Escola de Belas Artes, em Recife, e conclui a peça Lisbela e o prisioneiro, 
cuja estréia, em 1961, se realiza sem sua presença, pois Osman encontrava-se na Europa. Nesse mesmo ano, o romance $O$ fiel e a pedra, publicado no Rio de Janeiro, é premiado em Recife pela União Brasileira de Escritores (UBE).

Para iniciarmos nossa abordagem de Marinheiro de primeira viagem, julgamos fundamental reconstruir a ambiência em que se situava o romancista, contista, ensaísta, teatrólogo, crítico e poeta Osman Lins, para avaliarmos a sua formação cultural e literária, antes mesmo de ele ter ido à Europa e se dedicado a escrever sobre ela. Além de entender, melhor seu esforço em fazer uma viagem "iniciática", que irá contribuir, a partir de então, de maneira fundante na construção de seu universo literário. As viagens sempre estiveram muito ligadas à sua vida, mas agora não se tratava mais de viagens ficcionais, contadas ou imaginárias, que rondavam seus anseios, e sim do transporte efetivo a um local determinado a ser explorado: a Europa.

No ano de 1960, o último passado na cidade de Recife, Osman Lins recebeu a notícia de que ganhara uma bolsa de estudos da Alliance Française, com a qual iria para Paris, onde ficou por seis meses. Quando retornou da Europa, mudou-se para São Paulo ${ }^{10}$, em busca de espaço cultural mais promissor, em que pudesse ampliar seus projetos literários. Viveu nessa capital até a data de sua morte, em julho de 1978.

\section{I.3. O projeto da viagem à Europa}

Osman Lins tinha grande atração por conhecer o Velho Continente, e lá principalmente a França. Esse desejo de aproximação em relação à cultura européia, especialmente a francesa, era muito comum aqui no Brasil. Sempre que possível, nossos escritores viajavam para a Europa, com o objetivo de "ilustrar-se" e completar sua formação intelectual, de maneira mais acentuada "a partir do século XIX, quando nosso sistema literário encontrava-se, ainda, no processo de gestação de sua identidade" (NITRINI, 2000, p. 210).

Mas o autor aqui estudado tinha em mente que seu interesse não significava dependência de nosso país em relação à Europa, mas sim a consciência aguda de que "somos parte de uma cultura mais ampla”, como afirma Antonio Candido (2000, p. 154). Essa complementaridade de vivências culturais era-lhe necessária como intelectual. Consciente

\footnotetext{
${ }^{10}$ Em entrevista que Osman Lins lhe concede, em 29/12/1963, a jornalista Edna Savaget destaca o fato de que o escritor volta a ocupar "vitrines de livros novos com Marinheiro de primeira viagem", e comenta a chegada recente do escritor, assunto enfatizado pelo título da matéria: "Osman Lins mudou-se recentemente para São Paulo". A entrevista encontra-se parcialmente no Anexo 2, item 2.
} 
disso, ele afirmava precisar do encontro "com a civilização européia, contato que seria indispensável" "1 a sua formação de escritor, "que busca, em outras artes, alimento para sua literatura e para sua própria interioridade" (NITRINI, 2000, p. 215).

Ele já havia procurado, com muito empenho, apoio do governo francês para viabilizar seu sonho de permanecer por um período em Paris, mas não conseguiu. Diante da recusa, e do fato de não ter recebido nenhuma notificação sobre o resultado, Osman Lins escreve ao embaixador da França no Brasil, M. François Grégoire, uma carta, datada de 31 de janeiro de 1960, que pode ser lida, na íntegra, no Anexo I.

$\mathrm{Na}$ mensagem, além de lamentar não lhe ter sido comunicado que não receberia a bolsa pleiteada, ele aponta o fato de que vários dossiês, entre eles o seu, não chegaram em tempo hábil para a inscrição, por falha administrativa:

\begin{abstract}
Acuso o recebimento da sua carta $63 / \mathrm{FG} / \mathrm{GD}$, de 14 do corrente, pela qual fui informado, com surpresa, que é de praxe não ser feita comunicação alguma aos candidatos cuja bolsa não foi obtida. Nada sabia a respeito. Esperava, mesmo, o contrário, pois assim me prometia M. Lucien Pouessel, em carta mimeografada ref. 951 LP/MP, de 10-7-1959: "J'espère vous faire réponse de Paris avant la fin du mois de Juillet, et je souhaite qu'elle vous soit favorable". É claro que a carta prometia uma informação, qualquer que fosse a resposta da Direction Générale des Affaires Culturelles et Techniques.

Quanto ao motivo de meu dossiê, assim como dez outros, haver chegado a Paris "après le $1^{\text {er }}$ Juillet 1959 , c'est-à-dire après la date de clôture des candidatures", motivo que o senhor declara ignorar, é bem simples: meu dossiê deve ter saído dessa Embaixada "après le le $^{\text {er }}$ Juillet", pois ainda a 18 de junho, carta 749 LP/MP, M. Lucien Pouessel me escrevia, pedindo-me para preencher e remeter-lhe "deux formulaires état modèle $24 \mathrm{U}$, un dépliant et une copie du diplôme d'études secondaires". A 26 de junho, carta 854LP/MP, comunicava-me o recebimento dos referidos documentos. Ainda que os remetesse, nesse mesmo dia, para a França, dificilmente chegariam eles antes de $1^{\circ}$ de julho. E isto, parece, não foi feito, pois, a carta mimeografada a que me referi acima e que comunica o envio do dossiê, é datada de $1^{\circ}$ de julho ${ }^{12}$.
\end{abstract}

Nessa mesma carta, ele pleiteia a possibilidade de concorrer à nova candidatura:

Esperando, desta vez, ser mais afortunado em minha tentativa, envio, juntamente com um breve plano de estudos, o formulário que me foi enviado por V. S. Peço informarme se o meu dossiê do ano passado é válido para a nova candidatura. Em caso afirmativo, queira informar-me, pelo que muito lhe agradecerei, se devo acrescentar ao mesmo uma cópia da minha vida escolar e um certificado de conclusão de Curso de Dramaturgia, no qual obtive excelentes notas, o ano findo, na Escola de Belas Artes da

\footnotetext{
${ }^{11}$ Carta de Osman Lins de 05/02/1960 a Paulo E. de Berrêdo Carneiro, consultada no arquivo do IEB-USP. Reproduzimos esta carta no Anexo 1, item 2.

12 Carta de Osman Lins datilografada em 31 de janeiro de 1960 a M. François Grégoire, adido cultural da Embaixada da França no Brasil, Rio de Janeiro. Consulta feita no IEB-USP. A carta encontra-se no Anexo 1, item 1.
} 
Universidade do Recife. Se tais documentos são úteis à minha candidatura, enviá-losei, pois já os tenho em meu poder ${ }^{13}$.

Não foi possível localizar todas as cartas recebidas e enviadas por Osman Lins, em seu esforço de conseguir viajar para a Europa sob o patrocínio do governo francês, mas o que se depreende dessas menções é que foi muito intenso seu empenho em desfazer mal-entendidos e desencontros de informações.

Na correspondência de 5 de fevereiro de 1960, em resposta ao chefe da Delegação Permanente do Brasil na UNESCO, em Paris, o sr. Paulo E. de Berrêdo Carneiro, sobre uma carta que tinha enviado ao ministro da Educação da França, Osman elucida a dúvida sobre as mensagens serem "inexatas ou imprecisas as informações prestadas ao serviço diplomático do Brasil"14. E explica ainda:

$\mathrm{Na}$ referida carta, eu não manifestava propriamente o desejo de obter uma bolsa de estudos na capital francesa; apelava para o sr. André Malraux, em virtude de ter sido informado (informação esta recebida de fontes extraoficiais) de que a bolsa pleiteada por mim, com as melhores recomendações - Alceu Amoroso Lima, Gilberto Freyre e Aníbal Fernandes entre elas -, não fora concedida por motivo que a sua carta vem confirmar: estar, a Direção Geral dos Assuntos Técnicos e Culturais da França, concedendo apenas bolsas de caráter técnico.

Mas, após esclarecer e expor todos os seus argumentos, ele dirige-se ao sr. Paulo, demonstrando um misto de desânimo e conformação: “Assim sendo, recolho as minhas velas, meio abertas para viagens que decerto não farei e resigno-me a continuar aportado neste nosso Recife, entre as carteiras do Banco do Brasil, a cujos quadros pertenço" $"$.

Por último, ele ousa arriscar "mansamente, uma pergunta":

"Não encontraria V. Sa. motivos para requisitar-me, por uns seis ou oito meses, como funcionário junto a essa (para mim quase mitológica) Delegação Permanente do Brasil junto à UNESCO?" Confesso que seria, este, um convite que eu haveria de receber sem constrangimento algum.

A efetiva oportunidade de viajar com patrocínio surgiu após algumas tentativas frustradas. Osman Lins, finalmente, consegue a bolsa de estudos para ir à França, custeado

\footnotetext{
${ }^{13} I d .$, ibid.

${ }^{14}$ Carta datilografada de Osman Lins, de 05/02/1960. Consulta feita no IEB-USP. Reproduzimos esta carta no Anexo 1, item 2.

${ }^{15}$ Id., ibid.
} 
pela Alliance Française. Ele comentaria: “A bolsa era pequena, mas me proporcionava o mais difícil: meios para a travessia"16.

Sua conquista tornou-se pública e assim foi noticiada num jornal:

O escritor Osman Lins acaba de ser premiado com uma bolsa de estudos nos principais centros culturais de França. Num concurso de composição francesa, promovido pela Associação Cultural Franco-Brasileira, conquistou o primeiro $\operatorname{lugar}^{17}$.

Só restava preparar a documentação e tirar o passaporte, mas as dificuldades burocráticas que ele precisou enfrentar foram tão pitorescas, que acabaram registradas em Marinheiro de primeira viagem. Este foi o livro que ele escreveria logo após a experiência européia. Vale até destacar aqui, desta obra, o fragmento "Um burocrata" (p. 42, 43), que relata os transtornos de comunicação com o funcionário da repartição encarregado de preencher os formulários com os dados de Osman, traduzindo uma crítica ao caráter tacanho de certos serviços burocráticos. Firma também, e testemunha, seu empenho em viajar com uma atividade definida e explícita: a de escritor:

- Profissão?

- Escritor.

- Não pode ser. Não é isto que consta dos documentos do Imposto de Renda.

- Naturalmente. Não se paga Imposto de Renda como jornalista ou escritor.

- Tenho de pôr "bancário". O senhor não trabalha em Banco?

- Trabalho.

- Quer dizer que é escritor-amador.

- Existe rádio-amador, mas não escritor-amador. Ou se é escritor, ou não se é.

- Mas se o senhor trabalha em Banco, tenho de pôr "bancário".

- Não é como bancário, e sim como escritor, que viajo. A maioria dos meus possíveis contatos, na Europa, será de natureza artística e literária. Só vou entrar em Banco para trocar dólares. Como cliente. Não quero que o senhor ponha "bancário". Pode prejudicar-me. Já perdi uma bolsa de estudos porque, nos documentos, constava que trabalho em Banco.

- Pois eu só posso pôr "escritor", se o senhor provar que é escritor.

- Trago-lhe meus livros.

- $\quad$ Ah, não servem.

- Como é que não servem?

- É preciso trazer um documento, assinado por duas pessoas, atestando que o senhor é escritor.

- Selado?

\footnotetext{
${ }^{16}$ Esdras do Nascimento, Tribuna da Imprensa, RJ, 26/08/1963. Consulta no IEB-USP. Reproduzimos esta entrevista no Anexo 2, item 1.

${ }^{17}$ Diário da Noite, 22/11/1960. Trecho de notícia consultado no IEB-USP, que reproduzimos no Anexo 6, item 1 .
} 
- Perfeitamente. Com firma reconhecida.

- Então os livros não servem?

- Claro que não, meu senhor. Livro não é documento.

Mas, por fim, vencidas as inúmeras dificuldades, com a subsistência assegurada e um projeto cultural elaborado em detalhes, ele viajou na condição de escritor para a cidade de Bordeaux, na França, em fins de janeiro de 1961, uma segunda-feira. Este fato também saiu noticiado no jornal:

Osman Lins viajou. Domingo passado, para a França. Pretende se dedicar a literatura e teatro, aproveitando a bolsa de estudos ganha em concurso da Associação Franco-Brasileira, durante seis meses. Depois, de retorno ao Brasil, é possível que fixe residência em São Paulo ${ }^{18}$.

\section{I.3.1 A viagem de navio}

Osman Lins partiu de Recife, a bordo de um navio cujo nome era Manga. E, embora Marinheiro de primeira viagem trate estritamente dos meses de sua permanência no continente europeu, detalharemos também a viagem marítima, em função de informações a que tivemos acesso nos registros do autor, arquivados no Instituto de Estudos Brasileiros da USP (IEB-USP). Essa pesquisa revelou-nos que alguns eventos, no decorrer dessa travessia marítima, foram incorporados ao livro que ele escreveria sobre a viagem, como podemos observar no registro de bordo do dia 09/02/1961. Além disso, essa experiência assumiu o caráter de "retiro", para ele. Osman Lins, ao conquistar uma bolsa de estudos de seis meses na Europa, partiu para um período de reclusão e mergulho no passado cultural, como declara em seu diário de bordo, no registro do dia 31/01: "Esta viagem constitui uma espécie de retiro", o que significa recolhimento e retraimento do habitual.

O primeiro registro feito da viagem, por Osman Lins data de 30/01/1961 ${ }^{19}$. Neste seu manuscrito de bordo ele revela:

Tenho a surpresa, ao embarcar, de saber que somos 3 passageiros apenas: eu e um casal. Enquanto o navio se afasta, contemplamos a cidade. Olinda e suas igrejas. Um navio abandonado, com 2 pescadores que amarraram seu barco na escada.

\footnotetext{
${ }^{18}$ A fonte dessa notícia de jornal não foi encontrada. O fragmento do jornal está reproduzido no Anexo 6, item 2.

${ }^{19}$ Diário de bordo de 30/01/61. Arquivo sediado no IEB-USP. Grupo: Literatura. Tema: Marinheiro de primeira viagem. Notação: OL/LIT/MARINHEIRO/CX 1, P3. Evento: Composição do diário de Bordo.
} 
Arrumações, tristeza. A cidade despertava quando vim, de ônibus, pela Av. Norte.

O comandante Antoine Bertin nos convida para um aperitivo, antes do almoço. O maître é extremamente gentil. Calor. A trepidação do motor é um pouco enervante.

O navio segue em frente, e ele registra no dia $31 / 01 / 1961^{20}$ o sentido de reclusão que a viagem teve para ele, além de refletir sobre a impressão de desordem existencial que as mudanças de fusos horários lhe causariam:

Esta viagem constitui uma espécie de retiro.

Tivemos de adiantar os relógios uma hora. Isto me causou uma impressão estranha. Uma hora subtraída e que me será devolvida quando voltar. Os meridianos comeram uma hora da minha vida.

No diário de bordo desse dia, ele escreve sobre seu anseio de já fazer literatura, daqueles primeiros momentos ${ }^{21}$ :

Que tal, escrever um falso diário de viagem, com complicações sentimentais? Em existirem, no navio, apenas um padre e uma bela mulher? Ou uma mulher carola e um rapaz imaginativo? Ou uma mulher casada, um rapaz imaginativo e um padre? Mas se existe o padre, para que o rapaz?

Nesse mesmo dia ele comenta que os registros foram feitos com algum atraso:

${ }^{20}$ Id., ibid.

${ }^{21}$ A intenção de Osman Lins de escrever, futuramente, um livro de viagem já está patente em seu diário de bordo do dia 31/01. Esse objetivo confirma-se quando, em futura entrevista com Michel Butor, o autor francês revelalhe que está compondo um livro de viagem "à maneira dos móbiles de Calder", isto é, que rompe com o tradicional gênero literatura de viagem. O "entrevistador" (Osman Lins) diz ter a mesma intenção, embora seu plano não seja tão ousado como o de Butor, como se pode conferir em Marinheiro de primeira viagem, no fragmento "Entrevista com Michel Butor" (p. 69). Essa intenção expressa em Marinheiro... já foi discutida em "Viagem e projeto literário (Osman Lins na França)", p. 217-23, in Aquém e além-mar: relações culturais: Brasil e França (2000), por Sandra Nitrini. Acompanhemos o texto osmaniano:

Perguntas, assinalando as numerosas folhas de papel em branco e de papel escrito, que livro ele prepara, e este homem, que a ti mesmo prometeste ver quando ainda estavas no Brasil e que agora te fala, responde que termina um livro sobre os Estados Unidos, onde passou alguns meses, revelando-te sorrindo a intenção, que por coincidência é também a tua, embora no momento em que te fala ainda não hajas escrito uma só página e nem mesmo estejas certo de que chegarás a fazê-lo, de compor um livro de viagem que não se submeta à rotina do gênero aparentemente esgotado, sendo porém o seu plano bem mais ousado que o teu, seu livro Michel Butor planejando construí-lo um pouco à maneira dos móbiles de Calder, não obedecendo portanto a uma ordem cronológica, sendo a sua ordem, se existir, desmontável, passível de modificação, [...]. 
Estou tomando estas notas com atraso, pois só hoje, 3, decidi-me a fazê-lo. Mas estou quase certo de que não houve, nesta data, nada de notável a registrar. Arranjei 1 máquina para trabalhar. Mas tem o teclado vesgo e o lugar é quente.

No dia 01/02/1961, Osman Lins descreve outros momentos vividos no navio:

O capitão nos convida a visitar a passarela e nos mostra, com satisfação, os seus instrumentos. O vento, lá em cima, é mais forte do que eu poderia imaginar.

Aperitivo, (? $)^{22}$ capitão, para comemorar a passagem do Equador. Ponho discos brasileiros, que não chamam a atenção.

O maître se chama (?) Bernardini, não se casa porque acha essa vida pouco propícia ao casamento. Tem 3 irmãos e 1 irmã, todos casados. 6 sobrinhos. Tem dificuldade em suportá-los, habituado que está à vida de solteiro. Seu sonho, atualmente, é trabalhar em um transatlântico, o France, que é grande como o Normandie e que será batizado em maio. Será preciso saber alguma coisa de inglês e ele tenciona passar uns meses na Inglaterra.

A monotonia da viagem é grande:

A viagem desenrola-se sem novidade. Não vemos um peixe, um navio, um avião. A lua é cheia, mas o céu sempre com nuvens quase não nos permite vê-la.

Esses momentos são quebrados pelas conversas com o capitão:

Conversamos um pouco com o capitão, que fez a guerra e foi torpedeado, sendo recolhido 6 ou 7 horas mais tarde.

Mas, novamente, a rotina do navio:

Estendo, na ponte, abrigado do vento, minha colcha de retalhos. Eu e o companheiro conversamos até tarde. Na cabine, leio Du Gard até mais de 1/2 noite.

Registro do dia 02/02/1961:

Após o café, escrevo para Celi sem a (?), na sala de fumar. O maître está febril e atribui a febre à mudança de temperatura, pois começa a esfriar. Comemos hoje um fantástico poulet à diable. Depois do almoço, deito-me e sonho que vamos passar por terra (...)

Levanto-me, trabalho no artigo para o programa da comédia.

${ }^{22} \mathrm{O}$ sinal de interrogação não se encontra no original, mas foi utilizado todas as vezes em que o manuscrito apresentou-se incompreensível ou tivemos dúvidas quanto à clareza do escrito. 
O maître, com 39.4 de febre, diz estar com acesso de paludismo, mas não diz ao capitão. Após o jantar, ouvimos um pouco de música, jogamos ping-pong, sentamo-nos lá fora, viemos para a cabine. Leio até $1 \frac{1}{2}$ da manhã.

\section{O relógio lhe exigiu novo acerto:}

Tivemos que adiantar, de mais 1 hora, os relógios.

No dia 03/02/1961 Osman Lins assinala o cotidiano da viagem, detalhes da rotina de um navio e destaca:

Pôr-de-sol. Nunca vi igual. Um sol solitário, sem nuvens e sem cores em torno dele, descendo, amarelado, num céu pálido que se azulava no oriente. Não mergulhou no mar. Mas desapareceu por trás de uma névoa que não víamos.

Por trás da mesma névoa, no lado contrário, nasceu a lua, cor de cobre velho. Maravilhosa noite, estrelada, (?), a refletir-se no mar, com as 3 Marias erguidas sobre os mastros do navio.

No dia 04/02/1961, ele dá relevância ao sonho incrível que teve:

Sonho com seres que só poderiam ser demônios. Impossível reconstituir o sonho. $[\ldots]$

Sonhei também que encontrávamos, à noite, um belo navio, todo iluminado.

E a visão do sol:

Vejo, pela $1^{\mathrm{a}}$ vez, o sol mergulhar na água, num céu quase sem nuvens. (?) conversar com o cap. Que lê bastante. Aconselha-me a proteger-me contra o frio. Noite lindíssima e (?). Começo a escrever um artigo s/ LFT.

No registro do dia 05/02/1961, entre outras coisas, ele assinala:

O imediato fala de um satélite que passa de 2 em 2 horas, visível a olho nu. Após o almoço, eu e R. ficamos na ponte, sentados ao sol. Acontecimento notável, uma gaivota que acompanha o navio durante uns 5 minutos.

Dormir. Visto-me rigorosamente para o jantar. 


\section{O dia 06/02/1961 começa com novidade:}

R. vem chamar-me às $9 \frac{1}{2}$, dizendo que já avistamos Terra. Subo e vejo a ilha, as povoações, Las Palmas. Voam gaivotas em torno do navio, algumas pousam nas águas tranqüilas. Almoçamos e saímos, meio receosos. Mas apanhamos um motorista moço e simpático que, por 5 dólares passa conosco quase 3 horas, levando-nos inclusive para ver o vulcão extinto. (?) Lá no alto, vemos a cratera enorme, $[\ldots]$

Impressões da cidade: limpeza, ordem, calma e riqueza. Não se vê um carro velho, um papel jogado na rua. Flores. Horrível catedral, com um sacristão ainda mais horrível. [...] A lavadeira e seu traje. O chapéu, o lenço colorido. Nenhum cão na rua.

Nas notas do dia 07/02/1961 o registro é feito com detalhes, para um provável resgate futuro das lembranças:

Não esquecer o capitão, sua amabilidade viril. [...] E nos mostra o mar como se este fosse propriedade sua. Seu lar. Também não esquecer Pierre (?), sua maneira meio sorridente, e docemente irônica de olhar.

Nas anotações do dia 08/02/1961, em que ele afirma não haver quase nada a registrar, mas que tem sonhado muito, volta o interesse pela imagem da mãe desconhecida:

Praticamente nada a registrar. A não ser os sonhos. Tenho sonhado demais. Sonhei, entre outras coisas, perguntando a meu pai como era minha mãe. E me sentia pouco à vontade, porque ele respondia na frente de E.: Não posso lhe dizer bem, mas pode ficar certo de que ela era linda.

No dia 09/02/1961 Osman Lins escreve:

Hoje, vimos terra à direita, umas escarpas desertas Las Pontas de los Aguillones. Chegamos à Finisterra. Entramos no Golfo de Gasconha. Ondas largas, que têm feito oscilar enormemente o navio. Este mudou de direção. E, pela $1^{\text {a }}$ vez, o sol poente atravessou o longo corredor.

Encontro, na gaveta, um cartão de uma certa Julia a um certo Stéphane, da Bélgica. O cartão é feito no verso de um menu. Diz que, nas outras escalas, não houve tempo de escrever. Mas como vai passar 2 dias em Santos... são 7 linhas, animadas: Bien à toi. Pobre Stéphane ${ }^{23}$.

\footnotetext{
${ }^{23}$ Esse episódio do cartão endereçado a Stéphane, encontrado na gaveta a bordo do navio, vai aparecer mais tarde no Marinheiro de primeira viagem, embora nenhum manuscrito ou rascunho sobre o fragmento tenha sido encontrado. As revelações do diário de bordo remeteram-nos ao texto osmaniano, que ficcionalizou a situação, em "O destinatário" (p. 50). Osman Lins imprimiu um tom misterioso e detetivesco ao fato, como se pode conferir:
}

Numa gaveta do seu camarote, encontrara, dobrado em oito, um cartão postal de uma certa Julie, endereçado a um certo Stéphan Kaplan, Rue des Petits 
No dia 10/02/1961 ele registra a chegada do navio a Bordeaux:

À tarde, ancoramos diante de umas ruínas de um ancoradouro bombardeado pelos alemães. Ficamos esperando que a maré subisse para avançarmos rio adentro até Bordeaux. Às 9, ça commence. Uma cidade, à esquerda, cujo nome ignoramos, com as chaminés fumaçando à $1 / 2$ noite. Bordeaux, as árvores secas. Recebo no navio, carta do Rio assegurando a minha volta.

Dia 11/02/1961, sábado de Carnaval:

Os registros revelam já, "certa saudade do navio, dos maîtres, do comandante Antoine Bertin", de quem não quer esquecer-se.

Carmes, Bruxelas. Dizia, com uma espécie de cinismo amável, que, nas outras escalas, não tivera tempo de escrever. E que, como ia passar dois dias em Santos... Eram sete linhas.

Guardara o cartão consigo, na vaga esperança de que, indo a Bruxelas, poderia encontrar o seu destinatário, que responderia à leviana Julie, sem que esta pudesse descobrir como chegara às mãos do esquecido Stéphan aquela mensagem não posta no correio e que ela jogara... Onde? Não se lembraria.

Tirou da valise o cartão-postal, procurou saber onde ficava a rua, encontrou o endereço, um pequeno edifício de apartamentos. A concierge era velha, nervosa e tinha horror às correntes de ar:

- Queira fechar a porta! Por favor! Que deseja, afinal?

A seu lado, um velho taciturno, de longas barbas, com cara de guerreiro aposentado, olhava-os em silêncio. Um herói enfastiado.

- Mora aqui o Sr. Stéphan Kaplan?

- Sim, no segundo andar, 202. Mas é preciso bater com força.

Bater com força. Era certamente um velho e surdo, e não um homem jovem que amara a displicente Julie e a quem ela esquecera. Bateu com força, não houve resposta. No patamar, à parede, uma litografia representando Davi e o Rei Saul, e um velhíssimo retrato de Diana Durbin. Diana Durbin... Sobrevivência de que admiração juvenil? Voltou a bater, sempre inutilmente. A velha gritou de baixo:

- M. Kaplan certamente saiu! Inútil insistir.

Desceu, fez a pergunta necessária; que idade tinha ele.

- Monsieur Kaplan? Trinta anos, mais ou menos.

- E a senhora não conheceu, por acaso, uma certa Mademoiselle Julie?

- Feche a porta, pelo amor de Deus. Julie de quê? Como é ela?

- Isso é que eu queria saber. A que horas posso encontrar $M$. Kaplan?

- Ah! Ultimamente, ele está com um horário muito irregular. Há mesmo dias em que nem sequer o vejo.

- Então, não voltarei. Pode fazer-me um favor? Entregue-lhe este cartão. Adeus.

- Quem devo dizer que...

- Mas ele já batera a porta. Lançara, nas mãos da velha, um grão de mistério. Sentia-se feliz, como se acabasse de escrever um conto. 


\section{I.3.2 A estada na Europa}

Para abordar muitas das experiências que Osman Lins viveu nesse período recorreremos como fonte de informação ao próprio livro Marinheiro de primeira viagem, que concentra o que foi vivido pelo autor, além de seu diário de bordo, arquivado no IEB-USP.

Ele permaneceu na Europa por um período de seis meses como estudante de francês e também como colaborador do jornal O Estado de S. Paulo, para o qual entrevistou ${ }^{24}$ : Alain Robbe-Grillet, Jean-Louis Barrault ${ }^{25}$, Vintila Horia ${ }^{26}$ e Michel Butor. E, no que se refere a sua atividade jornalística, ele "cumpriu muito bem sua tarefa" e foi além, pois "revelou-se colaborador-escritor que, no exercício de sua função, assumiu-se enquanto par de seu entrevistado, recusando-se a repetir a fórmula clássica da entrevista"27.

Como exemplo, destaca-se a entrevista feita com Butor, que Osman Lins incluiu em Marinheiro de primeira viagem. Essa experiência realizada com o colega escritor está no fragmento intitulado "Entrevista com Michel Butor" (p. 66), em que ele parodia o estilo do autor de La modification $(1957)^{28}$, livro escrito na segunda pessoa do plural. Ele narra esse encontro na segunda pessoa do singular, como se pode conferir:

\footnotetext{
${ }^{24}$ As entrevistas realizadas por Osman Lins aparecem ficcionalizadas em Marinheiro de primeira viagem: com Robbe-Grillet, nos fragmentos "Robbe-Grillet" (p. 41), "Encontro" (p. 105) e "Com Robbe-Grillet" (p. 108); com Jean-Louis Barrault, no fragmento "Diálogo com Jean-Louis Barrault (p. 44); com Vintila Horia nos fragmentos "Exílio" (p. 24) e "Vintila Horia" (p. 46); e com Michel Butor, no fragmento "Entrevista com Michel Butor" (p. 66).

${ }^{25}$ Em seu diário de viagem, no dia 14/04, Osman Lins assinala que teve entrevista com Jean-Louis Barrault às 6 horas. Arquivo sediado no IEB-USP. Grupo: Literatura. Tema: Marinheiro de primeira viagem. Notação: OL/LIT/MARINHEIRO/CX 1, P3. Evento: Composição do diário de Bordo.

${ }^{26}$ Em seu diário de viagem, no dia 17/04, Osman Lins assinala que vai visitar Vintila Horia, com quem depois teve longa conversa. Arquivo sediado no IEB-USP. Grupo: Literatura. Tema: Marinheiro de primeira viagem. Notação: OL/LIT/MARINHEIRO/CX 1, P3. Evento: Composição do diário de Bordo.

${ }^{27}$ Sandra Nitrini, trabalho apresentado no VIII Congresso da Abralic, s/d.

${ }^{28}$ La modification (1957), de Michel Butor, hoje um clássico da literatura francesa, é também um romance de viagem. Butor escreve na $2^{\mathrm{a}}$ pessoa do plural (vous), e o encontro é reproduzido no mesmo tempo verbal do romance de seu entrevistado, parodiando-o, questão já assinalada em "Viagem e projeto literário (Osman Lins na França)", p. 218, in Aquém e além-mar: relações culturais: Brasil e França (2000), por Sandra Nitrini. A seguir, transcrevo um trecho de La modification (1957), como exemplo:
}

Vous avez mis le pied gauche sur la rainure de cuivre, et de votre épaule droite vous essayez en vain de pousser un peu plus le panneau coulissant. Vous vous introduisez par l'étroite ouverture en vous frottant contre ses bords, puis, votre valise couverte de granuleux cuir sombre couleur d'épaisse bouteille, votre valise assez petite d'homme habitué aux longs voyages, vous l'arrachez par à poignée collante, avec vos doigts qui se sont échauffés, si peu lourde qu'elle soit, de l'avoir portée jusqu'ici, vous la soulevez et vous sentez vos muscles et vos tendons se dessiner non seulement dans vos phalanges, dans votre paume, votre poignet et votre bras, mais dans votre épaule aussi, dans toute la moitié du dos et dans vos vertèbres depuis votre cou jusqu'aux reins (BUTOR, 1957, p. 9). 
Este que te recebe sorridente, à porta, de calças de flanela e paletó esporte de xadrez, tendo pela mão uma menina, certamente sua filha, de três ou quatro anos, e que ali está porque, entrando no edifício, cumpriste com o índex, depois de examinar a relação de locatários, no térreo, o botão correspondente ao seu nome, o que fez soar, no seu apartamento, uma discreta campainha, é Michel Butor, o autor de La modification. É, como vês, mais moço do que imaginavas, isto porém não te decepciona, antes te alegra, julgas ser mais fácil te entenderes com ele (LINS, 1980, p. 67).

Antes de partir do Brasil, Osman Lins havia elaborado um projeto cultural minucioso, para aproveitar ao máximo essa sua primeira viagem à Europa e absorver tudo o que ela teria a oferecer a um viajante profundamente interessado pelo mundo e atento ao que pudesse encontrar. "Nele, viajar é o antiturismo por excelência, se considerarmos turismo no sentido em que comumente é tido o deslocamento no espaço para ver coisas e gentes"29. A crítica aos que fazem turismo pelo turismo Osman registraria no fragmento "Os turistas" (p. 37), como se confere:

Há qualquer coisa de impudente, de tolo e de desrespeitoso nessas multidões de máquina em punho e óculos escuros, que são descarregadas pelos ônibus nos pontos 'pitorescos', com tempo marcado para o exercício da admiração pré-fabricada [...].

Quando lá chegou, ele comenta:

Não conhecia ninguém. Levava, é certo, algumas cartas de apresentação. Preferi, porém, só entregá-las quando estivesse um pouco mais familiarizado com a cidade, para não aparecer com ares de desamparado, de alguém que não sabe $s$ 'en d'ebarasser ${ }^{30}$.

Aos poucos ele foi se familiarizando com a situação, e pôde conhecer a Europa com olhar de escritor-viajante. Por onde passou, explorou intensamente o acervo cultural disponível, visitando cidades historicamente importantes, museus, livrarias, assistindo a espetáculos ou desfrutando de momentos calmos e serenos no Jardim de Luxemburgo em Paris.

No fragmento "Clandestino" (p. 74-5), Osman Lins externa a consciência aguda que tinha de sua situação, não se mostrando deslumbrado ou fascinado pela oportunidade em que se encontrava, e escreve:

\footnotetext{
${ }^{29}$ Massaud, Moisés. "Viajar e imaginar", Suplemento Literário, O Estado de S. Paulo, São Paulo, 08/02/1964, consulta feita no IEB-USP. Reproduzimos esta matéria no Anexo 3, item 3.

${ }^{30}$ Tribuna da Imprensa, RJ, 26/08/1963, entrevista a Esdras do Nascimento, consulta feita no IEB-USP. O texto na íntegra encontra-se no Anexo 2, item 1.
} 
De repente, enquanto se aprestava para a viagem à Itália, viu o quanto era precário tudo o que constituíra, naqueles últimos tempos, a sua vida. Seu passaporte autêntico, sua situação regular. Mas ele mesmo era clandestino num mundo que não lhe pertencia. Ali estava por uma concessão do destino, que lhe fazia presente de cidades e de relações humanas impossíveis. Tudo sem duração, veloz, esquivo, nada podia agarrar. Fora-se a primeira metade de maio, logo chegaria o mês de junho e então seria o fim. Partiria, daria adeus a gentes e lugares. E até amizades como a de João Márcio, que, no país estrangeiro, era como a de um irmão compreensivo, decerto viriam a diluir-se na distância.

Entre uma viagem e outra a Itália, Bélgica, Holanda, Espanha, Inglaterra, Portugal, Suíça, ele pôde encontrar em seu quarto, situado no Boulevard Raspail, da Maison de l'Alliance Française ${ }^{31}$, e depois em Montparnasse ${ }^{32}$, um porto seguro. Ele foi “adaptando-se, com rapidez, à sua vida nova e provisória. Como se ela fosse durar sempre. [...]”. À noite, de regresso, lavar roupa, estendê-la sobre o aquecedor, tomar um banho quente, voltar para o quarto (fragmento "As sensações reveladas", p. 26), remetia-o a "qualquer coisa da infância: era a mesma ilusão de permanência, de segurança, de paz imperturbável, além de todo o mal" (p. 27). Com isso, o "viajante" revela a familiaridade e a identidade com a nova situação em que se encontrava.

Sobre a diversidade e a origem dos outros residentes, ele comenta, no fragmento "Almoço" (p. 24), um momento de encontro com o diretor da Maison, "uma jovem de Manila, [...]; um norte-americano [...]; um iuguslavo [...]; uma australiana [...], uma espécie de cadinho das várias nacionalidades de seus hóspedes”.

Osman Lins relata e sintetiza: "Fui à Bélgica e Holanda. Voltei. Suíça e Itália. Voltei. Londres. Voltei. Espanha. Ainda voltei" ${ }^{33}$.

A experiência dessa estada na Europa teve para Osman Lins o sentido de complementar sua formação intelectual e de fortalecer seu projeto literário, razão pela qual ele não se afastou por um instante de seus objetivos, mesmo tendo conhecido "a experiência da solidão em terra estrangeira" 34 . No fragmento "O número encarnado no calendário" (p. 22-3), ele dá notícias de como sentia-se solitário:

\footnotetext{
${ }^{31}$ O endereço da Maison de l'Alliance Française era Boulevard Raspail, 101, apto. 409 - Paris, VI, segundo informação encontrada na carta que Osman Lins escreveu a Gilberto Freyre em 31/03/1961. Esta carta encontrase depositada no arquivo do IEB-USP. Ela consta, na íntegra, no Anexo 1, item 3.

${ }^{32}$ Sobre a mudança para Montparnasse, ele registraria o evento no fragmento "Mudança", em Marinheiro de primeira viagem.

${ }^{33}$ Tribuna da Imprensa, RJ, 26/08/1963, entrevista a Esdras do Nascimento, consultada no IEB-USP. Pasta: O livro, visto pelo autor. O texto na íntegra encontra-se no Anexo 1, item 1.

${ }^{34}$ Id., ibid.
} 
Estando sempre só, sem ninguém para trocar opiniões, para fazer confidências ou para recebê-las, uma criança desconhecida que às vezes lhe atirava um sorriso - num parque, numa rua - constituía um acontecimento, à noite recordado. Era, porém, nos domingos que a solidão o atingia de modo mais pungente. Lembrava-se de que, no Brasil, estava-se no meio do verão, de que o mar do Recife vinha se quebrar, espumoso e verde, na areia da praia. De que Ângela ${ }^{35}$ haveria de pôr seu maiô de listas coloridas, de que voltaria queimada, de que Litânia e Letícia passariam três horas dentro dágua, muito alegres, pessoas conversando nos cafés, por trás dos vidros. Aqueles seus primeiros domingos de Paris eram como os quadros de Rousseau.

Não tinha número de telefone; ao chegar da rua, ao entrar no seu quarto, sabia que ninguém lhe telefonaria. Isto não impedia que, ouvindo o telefone do vizinho, se equivocasse e, julgando ser um chamado para ele (de quem? De quem?), fosse atender, com injustificadas esperanças. Respondia e ninguém lhe falava do outro lado. Irritava-se por ver que o vizinho estava ausente, que o telefone tocava inutilmente, que alguém chamava o número de um quarto vazio, enquanto ele...

As viagens, para ele, não representavam um mecanismo para fugir ao tédio ou para buscar "mudanças de ares", eram, sim, oportunidade de aumentar os conhecimentos e de “ampliar os horizontes mentais" (LINS, 1979, p. 38)

Para Osman Lins, a experiência proporcionada pelo conhecimento de obras de arte em geral foi vastíssima e enriquecedora e como ele mesmo afirma:

minha temporada na Europa foi muito importante, porque eu a levei muito a sério, estabeleci programas muito rígidos de visitas a museus, concertos, de visitas a determinadas cidades, fui a Arezzo só para ver certos murais de pedra, fiz uma viagem rigorosa do ponto de vista cultural (id., ibid., p. 212).

E como o próprio autor põe em relevo: "Eu diria que a principal experiência desta minha temporada, que me marcou e marcará o resto da minha vida, foi o contato com os vitrais e com a arte românica, a arte medieval em geral” (id., ibid., p. 212). Fato que seu leitor tem a oportunidade de comprovar.

Ao fim do período programado, como ele lembra, "numa manhã bem semelhante àquela em que deixara o Brasil, disse adeus àquela cidade à qual chegara já no fim do inverno, cuja Primavera me encantara, e que agora eu via pela última vez, sob uma pesada chuva de

\footnotetext{
${ }^{35}$ Ângela, Litânia e Letícia são filhas de Osman Lins, de seu casamento com dona Maria do Carmo, em 1947.

${ }^{36}$ Muito tempo após sua primeira viagem, ele pôde avaliar os efeitos que essa exerceu sobre ele. Essas lembranças estavam presentes quando, em 03/07/1976, escreveu um texto crítico sobre um decreto emitido pelo governo brasileiro que exigia depósito prévio em dinheiro antes de viagens ao exterior. Com essa medida, pretendia-se incentivar o turismo interno no Brasil. O texto intitula-se "Isolamento cultural" e encontra-se, na íntegra, no Anexo 4.
} 
verão"37. Em seguida, ele vai para Portugal, seu último ponto de contato com a Europa, e depois parte de Lisboa para o Brasil. Desta vez, a viagem não é de navio: ele chega a Recife de avião.

Algum tempo depois, Osman Lins toma a decisão de registrar esse período de experiência na Europa, e o faz a partir de uma proposta literária nada convencional. Ele escreve então Marinheiro de primeira viagem, que vem a público em 1963.

\section{I.4. Escrever e esquecer}

Marinheiro de primeira viagem configura um momento de inovação no gênero literatura de viagem. Trata-se de "um livro extraordinariamente civilizado" 38 e difícil de ser enquadrado numa tipologia literária. É ainda pouco explorado, se o compararmos com outros trabalhos de Osman Lins, que receberam maior atenção por parte da crítica e dos leitores. Sobre ele paira uma declaração do autor, que diz tê-lo escrito para esquecer. Como se pode conferir:

A viagem [...] foi uma experiência marcante. Eu estava cheio de lembranças acumuladas. Elas me impediam de realizar tranqüilamente os trabalhos de ficção que antes me impusera. Então, planejei o relato, pus em ordem as recordações. [...], escrevi para esquecer (LINS, 1979, p. 132, grifo nosso).

Escrever e esquecer é uma expressão dotada de significado filosófico profundo, que prevalece sobre o sentido de abandono, ou de desqualificação, usualmente apreendido numa leitura mais superficial. Torna-se patente aquele significado principalmente quando a declaração vem de um escritor engajado na atividade literária e que se acreditava portador de um dom que o habilitava a "interpretar o mundo através das palavras" (LINS, 1979, p. 129).

Essa manifestação do autor não passou despercebida, e, como comenta Sandra Nitrini (1998, p. 59), embora verdadeiro em parte, não é relevante “que Osman Lins tenha escrito esse livro como uma catarse. Estava tão tomado pelas lembranças acumuladas no período da viagem, que se sentia impedido de realizar tranqüilamente os trabalhos de ficção planejados". E ela destaca: "O que é significativo é que Marinheiro de primeira viagem representa

\footnotetext{
${ }^{37}$ Tribuna da Imprensa, RJ, 26/08/1963, entrevista a Esdras do Nascimento, consultada no IEB-USP. O texto na íntegra encontra-se no Anexo 2, item 1.

38 Moutinho, Nogueira, "Um marinheiro de primeira viagem", Folha de S.Paulo, 27/10/1963, consultada no IEB-USP. Texto reproduzido no Anexo 3, item 5.
} 
importante elo entre os dois momentos" da obra do autor, configurados na fase mais realista e na fase antimimética.

Essa questão do esquecimento osmaniano também foi comentada por Graciela Cariello ${ }^{39}$, ao relacionar a expressão "escrever é esquecer" em Osman com outra semelhante, presente numa frase de Fernando Pessoa que está no Livro do desassossego, do heterônimo Bernardo Soares. Mas, em nenhuma declaração conhecida, Osman Lins admite um vínculo como esse estabelecido conscientemente. Essa autora mesma afirma que, apesar de idênticas no enunciado, as frases não parecem ter o mesmo sentido para os dois autores. Para Pessoa, a declaração leva à compreensão de que "a literatura é a maneira mais agradável de ignorar a vida" (PESSOA, 2000, p. 83, citado por CARIELLO, 2000, p. 6). "Não obstante, não podemos deixar de lembrar que para Pessoa o poeta é um fingidor que chega a fingir o que 'deveras sente"”, como está dito na Autopsicografia (id., ibid., p. 6).

Graciela Cariello encontra apoio para seu raciocínio num outro trecho, intitulado "Educação sentimental”, do próprio Livro do desassossego, em que o poeta apresenta um caminho para "evitar o sofrimento", que é "criar um outro Eu que seja o encarregado de sofrer em nós, de sofrer o que sofremos" (PESSOA, 2000, p. 310, citado em CARIELLO, 2004, p. 6). Por isso, segundo ela, "o escrever como modo de transformar aquilo que de demasiado pessoal há na vivência do escritor chega a ser para Osman Lins o mesmo recurso que para Pessoa [é] simular a vida" (id., ibid., p. 6). Ela observa que o emprego da terceira pessoa, por Osman Lins, tem por objetivo estratégico aproximar o relato de viagem ao romance, numa estratégia que procura fazer desse "“ele” o outro Eu de Pessoa” (id., ibid., p. 6).

Mas a declaração "escrevi para esquecer" de Osman Lins está aberta para uma outra linha de interpretação, que permite pensá-la sob a ótica do "querer dizer" de Derrida (19302004). Para isso, há a necessidade de remontarmos a Platão (427-347 a.C.) e ao tema do esquecimento provocado pela escrita, sobre o qual o filósofo discute, quase no fim de seu diálogo Fedro.

Aí, Sócrates conta a Fedro a origem da escrita, apontando como seu criador o deus egípcio Theuth, que a apresentou ao monarca Thamous. Segundo o deus, a escrita seria uma arte cuja prática teria o mérito de tornar os egípcios mais sábios. O rei, porém, não se convenceu, continuando a ver a escrita como uma prática maléfica, que tornava os homens

\footnotetext{
39 “Escrever é esquecer - Poéticas: Pessoa, Borges, Osman Lins", em V Congresso da Associação Portuguesa de Literatura Comparada, Faculdade de Letras da Universidade de Coimbra, em Portugal, $1^{\circ}$ a 4 de junho de 2004.
} 
esquecidos, pois, com a sua adoção, daí em diante só poderiam lembrar-se com o auxílio de sinais exteriores.

O assunto discutido entre Sócrates e Fedro acaba enveredando para o exame de uma distinção entre o discurso falado e o escrito, em que eles procuram determinar qual dos dois tem arte e qual carece dela. Sócrates desqualifica o discurso escrito, e para isso uma das razões alegadas por ele é sua impossibilidade de defesa ao ser "menoscabado, ou justamente censurado" (Fedro, 275e). A escrita, diz ele, é como as figuras pintadas que retratam homens vivos, as quais, se alguém as interrogar, permanecerão em silêncio; além disso, outro inconveniente do discurso escrito é o fato de distanciar-se de seu autor, sem "nunca se chega[r] a saber a quem serve e a quem não serve" (Fedro, 275e).

Em seguida, o filósofo ressalta a superioridade do discurso falado, pois nasce da sabedoria da alma de quem o profere: pela proximidade física, o falante pode estudar a reação de seu ouvinte e discernir o meio mais adequado para convencê-lo. Para ele, esse tipo de discurso é capaz de defender-se, "sabe quando convém ficar calado e quando convém intervir" (Fedro, 276a) e por isso é superior ao escrito. Por fim, Sócrates chega à conclusão de que a escrita seria nada mais que uma "simples representação da fala, esta sim capaz de produzir o verdadeiro conhecimento" (NASCIMENTO, 1999, p. 106).

Derrida, escavando as profundezas do diálogo Fedro, em seu livro A farmácia de Platão (1991), põe em evidência o "querer dizer" do "platonismo enquanto metafísica da presença" (id., ibid., p. 108), sua unidade de intenção, sua significação mais básica, encoberta por tantas interpretações ao longo dos séculos. Uma de suas grandes contribuições à filosofia foi identificar na dialética socrático-platônica algumas idéias que deram origem aos preconceitos da metafísica ocidental, como o logocentrismo, o fonocentrismo e o falocentrismo.

Derrida (1991, p. 21-2) explica que Thamous representa Amon, o rei dos reis, que é a máxima autoridade, mas não sabe escrever. O monarca é “deus-o-rei-que-fala", que procede como um pai autoritário, razão pela qual ele não aceita a escrita. Essa figura paterna e masculina, que detém o poder da palavra falada e que dá as coordenadas para que nada saia de seu controle, sintetiza os três preconceitos a que Derrida se refere. Só ele é capaz de examinar "os gêneros de discursos apropriados à persuasão de cada alma, e se, enfim, o discurso não tiver sido orientado de tal maneira que ofereça um teor complexo ou um teor simples, consoante a alma for, também, complexa ou simples!" (Fedro, 277c).

Sob esse aspecto, um texto pode dissimular o que está por baixo, e podem passar séculos, no caso do Fedro, 25, sem que se desfaça o tecido textual e se revele o que aí está 
dissimulado (DERRIDA, 1991, p. 7). É preciso descosê-lo para encontrar nesse desvelamento, fazendo o caminho de volta, o que foi tecido pela centralidade logocêntrica e assim chegar a perceber a mensagem que essa abertura pôde revelar.

Segundo Derrida, o "querer dizer" de Sócrates, que viveu num mundo predominantemente masculino, afirma a necessidade de que a mensagem, o logos (discurso), exija o seu autor, que é o dono e o pai de sua fala. A inteligibilidade do que é dito está a ele condicionada: o logos é um filho "que se destruiria sem a presença, sem a assistência presente de seu pai" (id., ibid., p. 22). Dada essa necessidade presencial, desqualifica-se a escrita, o que tem como conseqüência o esquecimento do autor.

A identificação, por Derrida, desses preconceitos (um dos quais, o de que a escrita leva a esquecer), que estão na base da acusação de Sócrates em relação à escrita, pode ampliar a compreensão da declaração de Osman Lins e de seu suposto desejo de esquecimento. Para o autor de Marinheiro de primeira viagem, inversamente, só o ato de escrever foi capaz de dar estabilidade a seu trabalho e de conseguir apaziguar a turbulência interior em que ele se encontrava. "Queria libertar-me da carga de lembranças, de laços, desfazer-me de tudo, deixar aquela viagem, aquela pausa e seu encantamento, para todo o sempre no passado. Coisa vivida. Coisa abandonada" 40 , ele declarou.

Uma vez registrada por escrito, a viagem que ele se propusera a ficcionalizar deixou de estar na linha de frente de sua memória, configurando-se, a partir do término do livro, como algo acabado e resolvido, que não mais poderia ser alterado. E, mais do que isso, a excitação provocada pela viagem e pelo processo criativo alcançaria equilíbrio, pois, corporificadas pela escrita, as lembranças se estabilizariam.

O "esquecimento" declarado por Osman Lins não é desqualificação, mas emancipação que ele concede a seu texto, que foi negada pela teoria socrático-platônica. Ao abrir mão de seu domínio e de seu controle, Osman Lins entrega a sua escrita ao leitor, para que ele a interprete e participe de sua viagem literária, ainda que, sob o desígnio desse destinatário, esta possa adquirir um caráter distinto do pretendido pelo autor. Ele não tem medo do parricídio que sua escrita possa vir a cometer. Esta pode continuar "a falar na ausência de seu pai, podendo vir a dizer aquilo que ele não teria dito" (NASCIMENTO, 1999, p. 107).

Pelas questões aí postas, Osman Lins demonstra que esse livro não é "um lançamento marginal, não é um acidente literário a esquecer. Mas um título apreciável, que se acrescenta a

\footnotetext{
${ }^{40}$ Em outra entrevista a Edna Savaget, "Os deuses nada arriscam”, no Jornal do Commercio, de Recife, 29/12/1963, que se encontra no Anexo 2, item 2, Osman Lins reafirma o que havia declarado na entrevista ao jornalista Esdras do Nascimento.
} 
uma obra responsável e madura, de escritor que vem construindo laboriosa e severamente a sua permanência” ${ }^{41}$, junto a seus leitores e críticos. E mais: é um livro fundamental para compreender-se as metamorfoses por que passou seu trabalho e que configura um momento de transposição de sua poética dos primeiros anos para uma linguagem altamente elaborada, fazendo jus ao designativo de "artesão da palavra”, que a crítica lhe atribui.

\section{I.5. Um projeto gráfico de Marinheiro de primeira viagem}

Alguns fragmentos, se tirados do lugar que ocupam no conjunto da obra, pouco parecem alterá-la, mas outros, se sofrerem mudança de posição, determinam alterações significativas de sentido. Aclara bem essa questão, observar os exemplos que se seguem:

\section{"Eurídice"}

Era a amiga da infância. Tinha os olhos negros e vivazes. Gostava de mangas. Leu, com ela, sentados os dois no mesmo sofá de vinhático, na sala da bisavó, um romance em quase duzentos folhetins: Sônia ou o Calvário do Povo Russo. Choravam, os dois, com as desventuras de Sônia, expulsa de casa, sob o inclemente inverno de São Petersburgo. Por que motivo, nestes últimos dias, lembra seguidamente seus olhos inquietos, o sofá de vinhático, a sala da bisavó e os percalços de Sônia, heroína russa? (LINS, 1980, p. 66).

Sabendo que o narrador fala da amiga de infância, que se chamava Eurídice, e de momentos de seu passado, não podemos deixar de lembrar que Eurídice, no mito do poeta grego, era o nome de sua amada e que representa a tentativa frustrada de recuperar o passado. O fragmento seguinte, cujo título é "Mensagem" (LINS, 1980, p. 66), com apenas duas linhas e meia, pode ser lido como uma extensão desse que acabamos de ler (o anterior), cuja mensagem pode ser interpretada, como o tempo é a solução para resolver todos os problemas, e o encarregado pelo abrandamento das coisas, como se pode conferir:

\section{"Mensagem"}

"Na Chargeurs Reunis, faz a reserva para a sua volta, atento ao significado desta providência, mensagem cifrada que lhe diz com ironia: 'Tudo passa, amigo"” (id., ibid.; grifo nosso).

\footnotetext{
${ }^{41}$ Ramos, Ricardo. "Paisagem interior de Osman Lins", O Estado de S. Paulo, São Paulo, s/d., n. 420, consultada no IEB-USP. O texto, na íntegra, encontra-se no Anexo 3, item 6.
} 
O nome Eurídice, referido na citação anterior, não se usa impunemente; ele sempre vem carregado da carga emocional e histórica do mito e sempre associado ao de Orfeu. Um paralelo que podemos traçar é com a imagem de Don Quixote e de Sancho, os quais não conseguimos dissociar das gravuras de Doré (1832-83), por mais que tentemos criar uma outra imagem, para esses dois personagens de Cervantes, a força da figuração que Doré imprimiu em nosso imaginário não pode ser desfeita. Igualmente, do nome de Eurídice não podemos subtrair o passado que seu nome conota, sua ligação com Orfeu e toda a história mítica que implica.

Osman Lins foi um autor que se recusou a adotar "fórmulas gastas e fáceis" e procurou explorar "novos campos" (LINS, 1979, p. 257). Declaradamente interessado nas figuras geométricas, ele desenvolveu, com base numa delas, uma estratégia muito peculiar para organizar o caos de suas lembranças ao escrever Marinheiro de primeira viagem. Tinha em mente que, para ele, a "forma é a idéia viva da obra e o que, na obra, há de mais pessoal"42.

Com o claro objetivo de ressaltar a estrutura geométrica que sustenta os relatos e tornar imagética a sua arquitetura, serão apresentados alguns gráficos. O primeiro deles foi elaborado a partir das declarações de Osman Lins sobre a sua organização: "O livro obedece a uma construção, a um plano. Se as primeiras impressões se fundem com as últimas, é para dar a impressão de um círculo"43.

O segundo, terceiro e quarto gráficos surgiram por uma aproximação minuciosa e familiar do livro, que revelou ligações entre os fragmentos que não haviam sido apontadas pelo autor. Eles estão literalmente relacionados, como se pode acompanhar nas demonstrações a seguir.

\footnotetext{
${ }^{42}$ Informação encontrada em manuscrito do autor, pesquisado no IEB-USP. Caixa 2: Grupo Magistério. Evento: Programa, planos de cursos e artigos publicados durante as atividades acadêmicas. Plano de aula: Em que medida é consciente o trabalho do ficcionista? Pasta 2.

${ }^{43}$ Entrevista a Esdras do Nascimento, Tribuna da Imprensa, RJ, 26/08/1963. Reproduzimos esta matéria no Anexo 2, item 1.
} 


\section{Primeiro gráfico: A arquitetura geral do livro}

Esse gráfico representa a obra como um todo. O primeiro fragmento une-se ao último e abrange todos os outros. Dessa maneira, as lembranças que compõem Marinheiro de primeira viagem ficam todas envolvidas nessa estrutura circular, característica da forma mítica de conceber o mundo, tema que será desenvolvido no Capítulo II.

O fragmento inicial (sem título) está ligado ao último fragmento "O Anti-Orfeu".

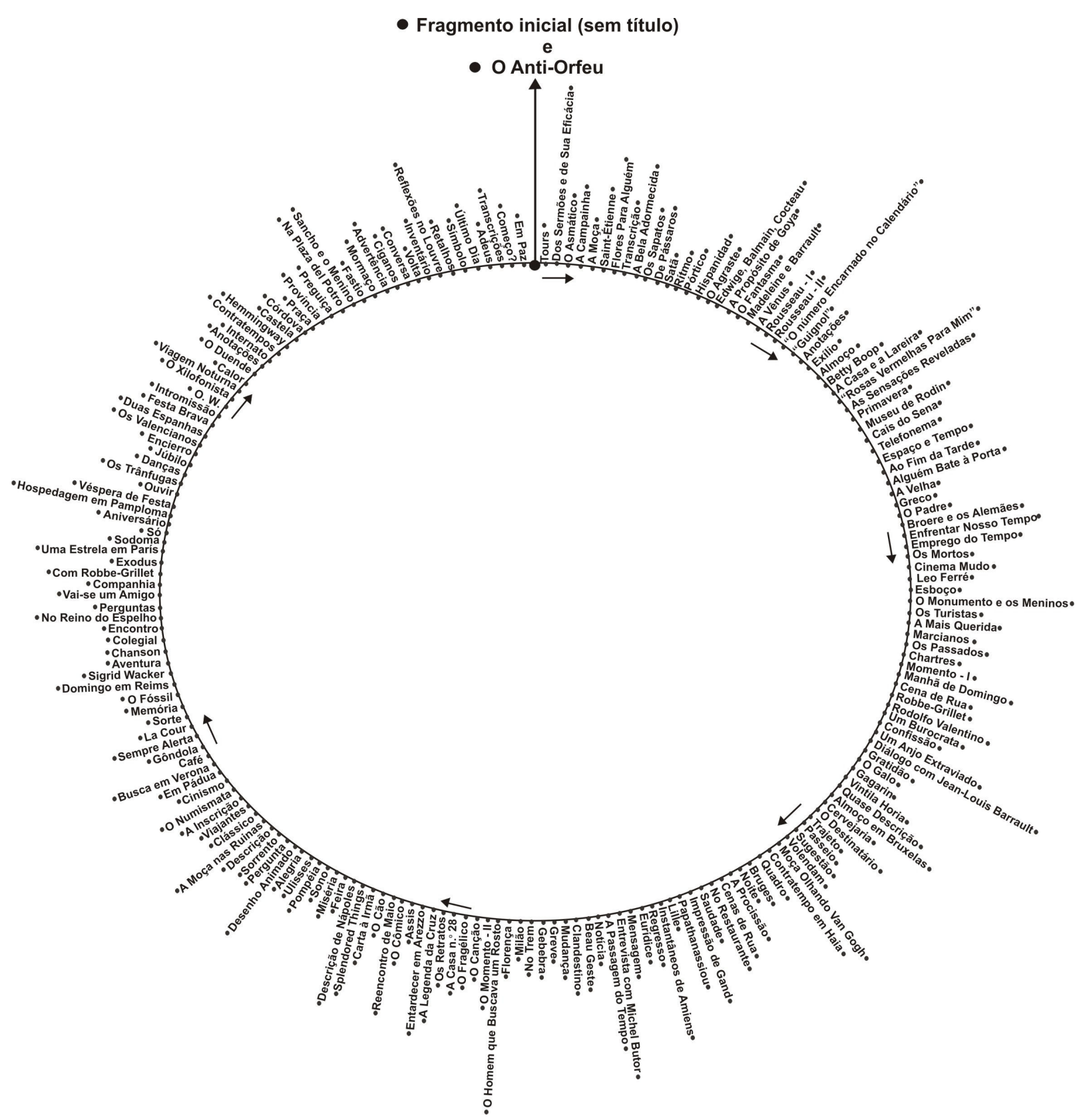




\section{Demonstracão:}

\section{Fragmento inicial (sem título) ${ }^{44}$}

[...] Que se evoquem, hoje, o desembarque em Bordéus, num sábado de Carnaval, as primeiras horas neste continente. $O$ dia era cinzento $\boldsymbol{e}$ frio. Brilhavam, nas frontarias escuras, os cartazes de publicidade, com peixes vermelhos e verdes, parecendo feitos de rosas e folhagem [grifo nosso]

$[\ldots]$

Entra, à noite, num clube chamado L'Aiglon. Desembaraça-se das luvas, do sobretudo, e tem acesso, por três ou quatro francos, àquele forno onde centenas de jovens se divertem. [grifo nosso]

Fragmento "O Anti-Orfeu"45

Logo ficará para trás o continente, com sua carga de gente e de passado. Amanhã será um dia de sol. Ainda cedo, os Márcios irão sair com ele de automóvel, percorrerão Lisboa, almoçarão os três, alegremente. Peixes. Conversas finais. Recordará o desembarque em Bordéus, a cinza, a solidão e o frio daquela primeira manhã européia, [...]. Havia um clube chamado L'Aiglon? [grifo nosso]

${ }^{44}$ Osman Lins, Marinheiro de primeira viagem, p. 7-8.

${ }^{45}$ Osman Lins, Marinheiro de primeira viagem, p. 142. 


\section{$\underline{\text { Segundo gráfico: }}$}

A narrativa do Fragmento inicial (sem título) está relacionada com a narrativa do fragmento intitulado "Começo?".

Desse círculo, representado no gráfico abaixo, só ficaram de fora os dois últimos fragmentos, "Em paz" (p. 142) e "O Anti-Orfeu" (p. 142-4), que tratam dos últimos momentos do "viajante" em Portugal. Nessa última etapa, quando já tinha praticamente terminado sua viagem, ele vai se despedir de tudo e de todos, em especial, dos amigos portugueses, a "família de amáveis corações".

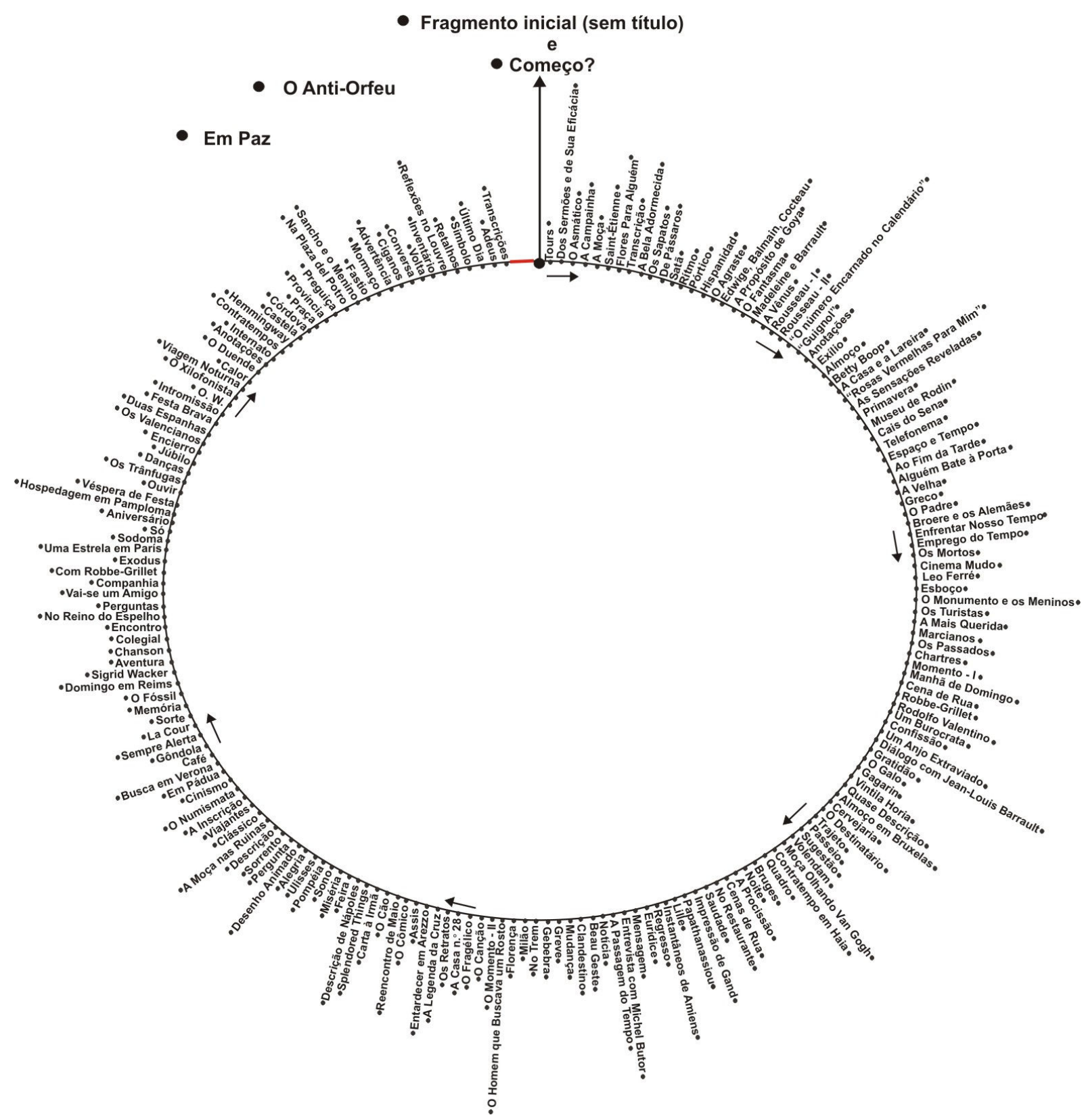




\section{Demonstração:}

Fragmento inicial (sem título) ${ }^{46}$

\section{Fragmento "Começo?"47}

[...] Acabava de chegar a Lisboa, está num velho hotel - cujo nome, por displicência ou fadiga, não reteve - e onde jamais voltará a hospedar-se, mesmo que um dia aqui regresse, pois virão em breve demoli-lo, por causa do metrô. Hotel condenado à morte. (Vibram, implacáveis, as perfuratrizes.) [...] Ouve-se, na rua, o barulho das perfuratrizes, que já fazem tremer as paredes muito velhas. [...] Numa das portas, num vidro, há uma japonesa cosendo [grifo nosso].

As perfuratrizes esburacam a rua, vibram as paredes, estremece no vidro a japonesa. [...] Mais forte o barulho das máquinas, embaixo. [grifo nosso]

${ }^{46}$ Osman Lins, Marinheiro de primeira viagem, p. 7-8.

${ }^{47}$ Osman Lins, Marinheiro de primeira viagem, p. 142. 


\section{Terceiro gráfico:}

O que caracteriza a união desses dois fragmentos, representados no gráfico abaixo, é o toque dos bastões de bronze que se chocavam entre si e saudavam as pessoas que entravam e saíam da "lojinha". A localização de "A campainha" no início do livro sugere o sinal de evocação das lembranças e em "O Anti-Orfeu", que fecha o livro, indica um outro momento de "passagem", o rito de saída, para deixar "aquela pausa e seu encantamento, para todo o sempre no passado", como declarou o próprio Osman, em sua entrevista a Esdras do Nascimento que se encontra no anexo. O fragmento "A campainha" está relacionado ao fragmento "O Anti-Orfeu”, só ficaram de fora "O Asmático", "Dos Sermões e Sua Eficácia", "Tours" e o fragmento inicial (sem título), como se pode observar na representação do livro, que está abaixo:

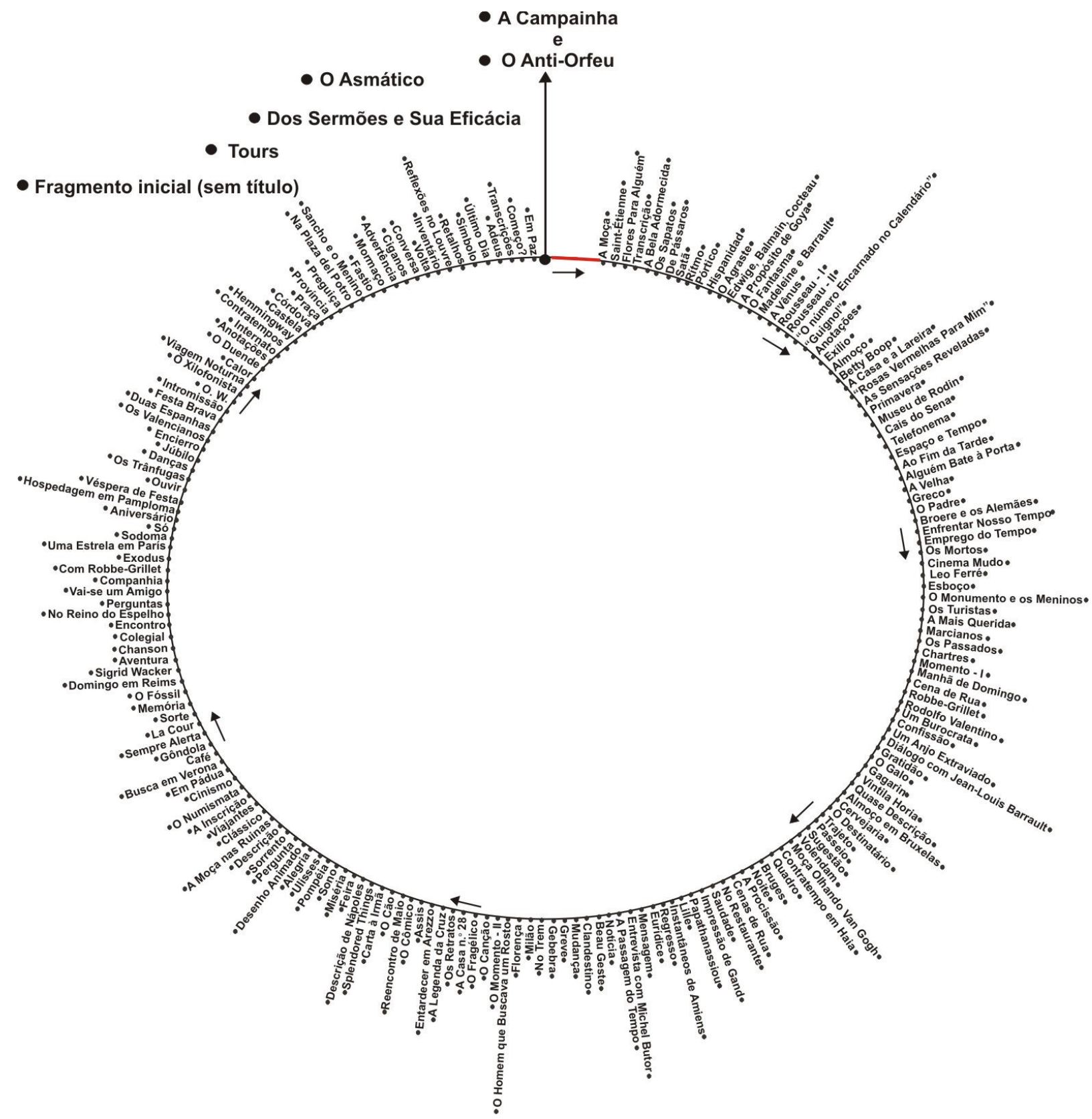




\section{Demonstraç̃o:}

Fragmento "A campainha" 48

[...] bastões de bronze de várias dimensões, na lojinha onde entrou para comprar umas vistas da cidade, e que, se se movia a porta, chocavam-se entre si, produzindo sons tão doces, tão amáveis, que as pessoas de súbito se tornavam crianças e desejavam entrar, sair, durante horas, para abrir e fechar aquela porta, cujos bastões de bronze estão eternamente prontos a saudar, com sua música idêntica a si mesma e, todavia, variável ao infinito, todos que entram, todos que se vão. [grifo nosso].

Fragmento "O Anti-Orfeu"49

Entre os ramos nus das árvores em Tours, esvoaçavam pássaros. Batia, a espaços, o portão de ferro do jardim. Os bastões de bronze da lojinha, de várias dimensões, chocavam-se entre si. As pessoas tornavam-se crianças, e desejavam entrar, sair, durante horas, para abrir e fechar aquela porta, com seus bastões eternamente prontos a saudar, com a música idêntica a si mesma e, todavia, variável ao infinito, todos que entram, todos que se vão. [grifo nosso]

${ }^{48}$ Osman Lins, Marinheiro de primeira viagem, p. 10.

${ }^{49}$ Osman Lins, Marinheiro de primeira viagem, p. 143. 


\section{Quarto gráfico:}

Assim como o diagrama anterior, a característica da união desses fragmentos é também um movimento de entrada e de saída.

O fragmento "Tours" repete-se no fragmento "O Anti-Orfeu". Fica de fora somente o fragmento inicial (sem título), como se observa:

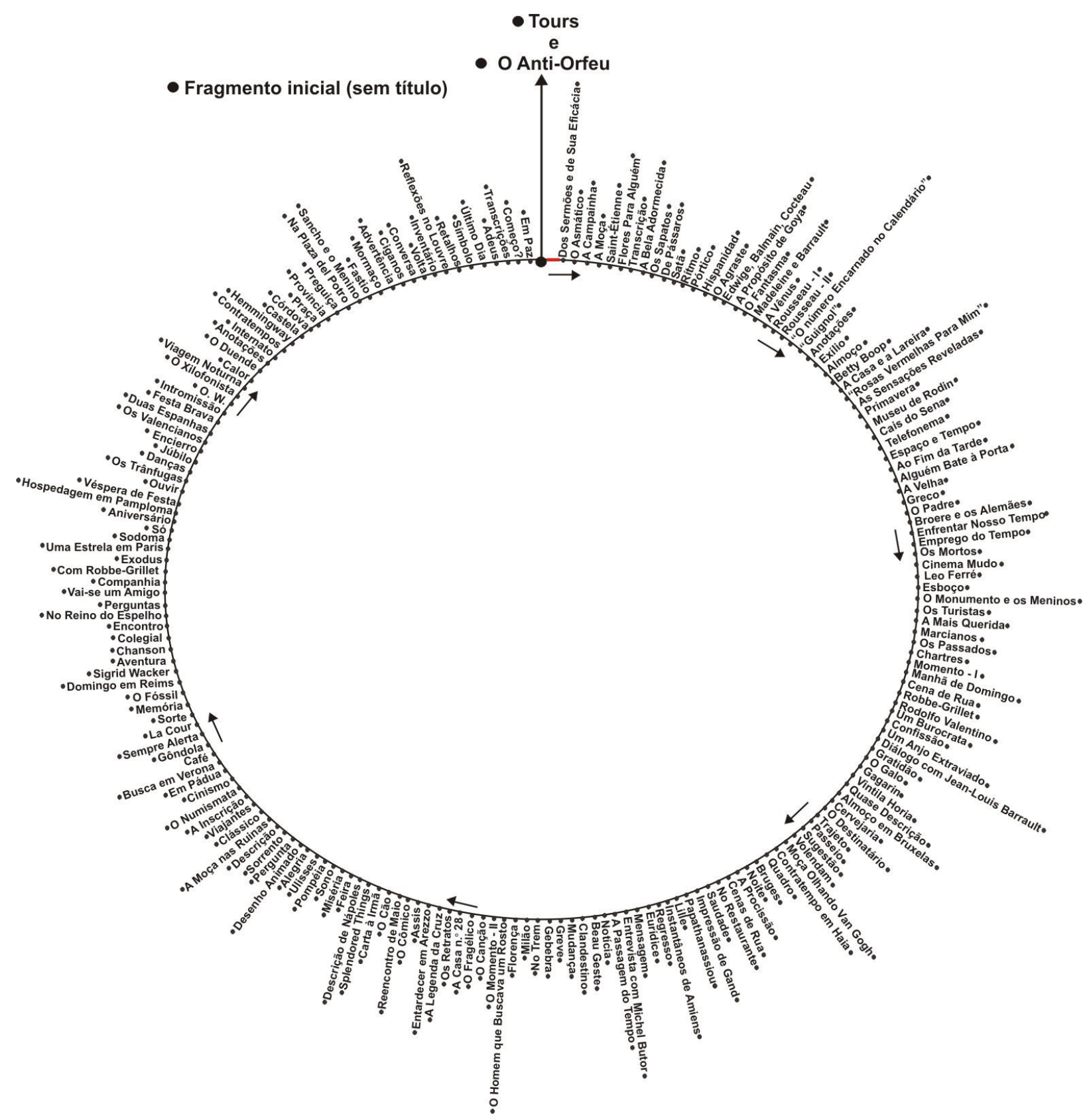




\section{Demonstraç̃o:}

Fragmento "Tours" 50

[...] Num banco próximo, duas adolescentes conversam. Uns poucos pássaros piam e esvoaçam entre os ramos nus das árvores. Passam casais, empurrando carrinhos de criança. Bate, a espaços, o portão de ferro do jardim. [grifo nosso]

Fragmento "O Anti-Orfeu"51

Entre os ramos nus das árvores, em Tours, esvoaçavam pássaros. Batia, a espaços, o portão de ferro do jardim [grifo nosso].

${ }^{50}$ Osman Lins, Marinheiro de primeira viagem, p. 8.

${ }^{51}$ Osman Lins, Marinheiro de primeira viagem, p. 143. 


\section{Conclusão das demonstrações:}

Com os quatro gráficos apresentados anteriormente, pretendemos demonstrar visualmente e literalmente as ligações e interrupções entre as várias narrativas do livro. Essa prática osmaniana, que se destacou e se tornou um estilo, em suas obras posteriores, já se apresenta em Marinheiro de primeira viagem. Essa ocorrência é, a nosso ver, o embrião que ele desenvolveria, aperfeiçoaria e solidificaria nas linhas narrativas e na escrita não-linear de seus trabalhos futuros. Portanto, o que aproxima esse livro das outras produções do autor, não é só a experiência da viagem à Europa nem só a narração em pequenos fragmentos, mas os cortes, as retomadas e as repetições, como já acontece em Marinheiro de primeira viagem. Além disso, ao mesmo tempo em que as rupturas fazem parte de sua estética, tudo se passa sob o comando de uma linha diretriz e organizadora, que, no caso desse trabalho do autor que ora exploramos, é o mito de Orfeu, conforme detalharemos no capítulo II. Detalhe esse, ainda não assinalado na fortuna crítica de Marinheiro de primeira viagem.

Em função da necessidade dessa visibilidade, enxergamos nesse recurso visual que elaboramos um grande auxiliar na compreensão da arquitetura de Marinheiro de primeira viagem. Além disso, vimos aí também uma forma de contribuir para um melhor equacionamento desse livro de "passagem", algumas vezes mal interpretado por parte de alguns críticos, tornando mais fácil relacioná-lo às outras fases de sua escritura e, portanto, contribuindo de modo capital para que sejam entendidos os rumos da escrita futura de Osman Lins. 


\section{CAPÍTULO II}

\section{UM OLHAR POÉTICO SOBRE MARINHEIRO DE PRIMEIRA VIAGEM}

Eles não sabem que o sonho é tela, é cor, é pincel, base, fuste, capitel, arco em ogiva, vitral, pináculo de catedral, contraponto, sinfonia, máscara grega, magia, que é retorta de alquimista, mapa do mundo distante, rosa-dos-ventos, Infante, caravela quinhentista, que é cabo da Boa Esperança, ouro, canela, marfim, florete de espadachim, bastidor, passo de dança, Colombina e Arlequim, passarola voadora, pára-raios, locomotiva, barco de proa festiva, alto-forno, geradora, cisão do átomo, radar, ultra-som, televisão, desembarque em foguetão na superfície lunar

(António Gedeão, “Pedra filosofal”. In: Movimento perpétuo, 1956)

\section{II.1. Como o autor gostaria que seu livro fosse lido}

Ao escrever Marinheiro de primeira viagem, Osman Lins teve o cuidado de registrar suas recordações de modo que o leitor não viesse a encontrar relíquias do tempo, nem "os lugares comuns" com descrições pormenorizadas que um "viajante possa encontrar" (LINS, 
1979, p. 132). Ele faz questão de afirmar que seus relatos tratam do fugaz, do que não se repete:

Tomei outras providências. Eliminei do livro, a priori, a descrição de tudo que o possível leitor, acaso viaje, venha a descobrir. Ou possa ler em manuais de turismo, nas enciclopédias ou em compêndios de Geografia. Meu livro não trata do permanente: é do transitório que se ocupa. Do único. Do que não virá a repetir-se. Não iria cometer a impertinente asneira de dizer como é a Torre Eiffel ${ }^{1}$.

O interesse declarado pelo autor era de que o possível leitor de seu livro o procurasse com a expectativa de ler uma obra literária, e sobre isso ele comenta:

Falo de corridas de touros, de outras festividades públicas, de Veneza, de Córdova e Sorrento, de Londres, mas também de gente que apenas entrevi, com quem cruzei numa rua, com quem viajei num trem, desde que, literariamente, fui estimulado ${ }^{2}$.

No fragmento "Saudade" (LINS, 1980, p. 63), em que se dá destaque à visita à cidade belga de Bruges, um lugar que muito o impressionou, ele observa:

A cidade é bela e senhoril, com suas velhas mansões, suas numerosas torres, pontes e canais $[\ldots]$, onde sempre se ouve o rumor dos próprios passos, e com o carrilhão de sua catedral, que soa de 15 em 15 minutos.

Essa cidade ele amara por seu recato, nobreza e mistério, mas o que literariamente fixou foi uma situação comum, que, com certeza, não se repetirá, como se pode conferir:

\begin{abstract}
Mas não era de Bruges que sentia saudades. Hesitava em deixar era o hotel, gostaria de permanecer mais tempo ali, com aquele garçom já meio velho, que nascera em Bruges, puxava por uma perna, que falava tanto do passado e que ficava às vezes em silêncio, de pé olhando para fora; com a apressada mulher do proprietário, que se parecia com Píer Angeli, [...]. Lentamente, retardando a partida, arrumou seus pertences, despediu-se, deixou talvez para sempre este quarto de hotel, com sua janela de vidros coloridos (LINS, 1980, p. 63; grifo nosso).
\end{abstract}

Sobre o tom de seu livro, Osman Lins, em entrevista ao jornalista Esdras do Nascimento, diz que não queria parecer melancólico nem imprimir "ar de lamentação". Manifesta nessa oportunidade como gostaria que seu livro fosse recebido pelo leitor:

\footnotetext{
${ }^{1}$ Entrevista concedida a Esdras do Nascimento, Tribuna da Imprensa, Rio de Janeiro, 26/08/63, cujo texto, na íntegra, encontra-se no Anexo 2, item 1.

${ }^{2}$ Id., ibid.
} 
Não é meu desejo que o possível leitor de Marinheiro de primeira viagem venha a procurá-lo com a ilusão de viajar através de suas páginas. Desejaria que ele abrisse o livro com uma expectativa de outra natureza, a meu ver legítima: a de ler um livro. Pois é isto, afinal, o que pretende ser o meu trabalho: um livro. Uma obra literária.

Se ele quisesse ser, antes de tudo, um relato de viagem, eu não teria omitido, ao escrevê-lo, fatos em si mesmos "importantes" como a visita à cidade de Rouen.

Falo de corridas de touros, de outras festividades públicas, de Veneza, de Córdova e Sorrento, de Londres, mas também de gente que apenas entrevi, com quem cruzei numa rua, com quem viajei num trem, desde que, literariamente, fui estimulado ${ }^{3}$.

No fragmento "Advertência" (LINS, 1980, p. 133), o leitor é informado de que a proposta dos relatos não é refletir fielmente o que se passou na viagem, porque o passar do tempo modifica as lembranças e o real significado das coisas. Com esse dado, encontrado praticamente no final do livro, o escritor dá sinais de que os fragmentos podem ser lidos fora de uma ordem seqüencial, embora o livro obedeça a uma organização circular, como demonstramos anteriormente. Para o autor, o que surge à memória no momento dos registros são os pequenos detalhes observados durante as visitas. Ele faz questão de acentuar que o fugaz tornou-se permanente, e o que se costuma reputar importante revelou-se fugaz:

Não se creia que este livro reflita, exatamente e sempre, o que foi sentido na viagem. Pois é escrito ao longe, sob uma perspectiva que o passar dos dias modifica. Assim, incidentes banais, aos quais mal se prestou atenção, surgem agora carregados de sentido; enquanto se afiguram, não propriamente insignificantes, mas mortas, não oferecendo ao ato de escrever nenhum estímulo, visitas demoradas e até minuciosas, como a feita ao Alcazar de Granada, da qual só uma coisa restou: a claridade da sala de banhos, uma claridade de bosques no verão (id., ibid.).

Como ressalta Nogueira Moutinho ${ }^{4}$, a experiência de Osman na Europa deve ser comparada à dos "verdadeiros viajantes: Fernão Mendes Pinto na China, Stendhal na Itália, Ramalho Ortigão na Holanda, Xavier de Maistre à roda do quarto, Garret na terra dele, Sterne na terra dos outros..."

Em Marinheiro de primeira viagem, os registros não foram feitos como em $O$ turista aprendiz (livro só publicado em 1976, mas que reúne material escrito em 1927 e 1979), obra de Mário de Andrade, em que o autor relata a sua viagem etnográfica pelo Amazonas até o

\footnotetext{
${ }^{3}$ Entrevista concedida a Esdras do Nascimento, Tribuna da Imprensa, Rio de Janeiro, 26/08/63, consultada no IEB-USP. Esse texto, na íntegra, encontra-se no Anexo 2, item 1.

${ }^{4}$ Moutinho, Nogueira. "Um marinheiro de primeira viagem", Folha de S.Paulo, 27/10/63 (IEB-USP). Artigo reproduzido no Anexo 3, item 5.
} 
Peru, pelo Madeira até a Bolívia, passando pela ilha de Marajó. Os registros começam numa data precisa $(07 / 05 / 1927)$ e terminam em outra (05/02/1929). Marinheiro... também não se propõe a ser como La Paz existe? (1977), o outro livro de viagem de Osman Lins, escrito em conjunto com sua mulher, a escritora Julieta de Godoy Ladeira. Em parceria, eles contam as experiências da viagem que fizeram ao Peru, em que os registros são feitos como os de um repórter. "Nada inventamos. Tudo se passou, exatamente, como está no livro, [...]", ele afirma.

\section{II.2. O diálogo viagem-arte}

Quando Osman Lins voltou para o Brasil, não conseguia retomar seu trabalho narrativo, mas, como se via envolvido pelas lembranças da viagem encantatória, que não o abandonavam, decidiu registrar suas memórias e escreveu Marinheiro de primeira viagem. A elaborada construção de sua narrativa em fragmentos possibilita ao leitor acompanhar tanto o diálogo cultural do autor com a tradição quanto sua experiência singular de viajante, em passagens marcadas por intensa poeticidade.

Os registros transcendem os momentos reais, não obedecem a uma ordem cronológica nem a uma linear. Um narrador “descreve o que um fictício 'ele', viajante noviço na Europa”, passou e sentiu (IGEL, 1988, p. 163). Com esse recurso, Osman Lins consegue a "diminuição psicológica da pessoa do viajante" e dá um formato ficcional às próprias vivências, “entregando, assim, ao leitor, a viagem em si e não a sua pessoa-em-viagem" (id., ibid., p. 163-4).

Cumpre ressaltar que essa narração em terceira pessoa não é uniforme, em alguns momentos o escritor "aparece na primeira pessoa, é como se fosse o próprio viajante (isto é, o ficcionista) que toma a palavra" ${ }^{, 5}$ : ele recorre às aspas, que marcam as passagens da terceira para a primeira pessoa, a exemplo do que ocorre em alguns fragmentos, como "Transcrição" (LINS, 1980, p. 13), "De pássaros” (p. 15), “A propósito de Goya” (p. 18-9), “Anotações” (p. 23-4), "Betty Boop" (p. 25), "Telefonema” (p. 28), "O padre” (p. 33), "Chartres” (p. 40), “Confissão" (p. 43), "Beau, Geste” (p. 72-4), "Numismata" (p. 96-7), "Exodus” (p. 110-1), "Valencianos" (p. 118) e "Transcrições" (p. 138-42).

\footnotetext{
${ }^{5}$ Massaud, Moisés, "Viajar e imaginar", O Estado de S. Paulo, São Paulo, 08/02/64. Suplemento Literário, consulta feita no IEB-USP. Reproduzido no Anexo 3, item 3.
} 
A opção por esse tipo de narração facilitou, também, o registro de alguns eventos de ordem pessoal, íntima e profissional, como as entrevistas realizadas com os escritores franceses, já destacadas no Capítulo I; as cartas familiares, que podemos conferir nos fragmentos "Chartres" (p. 40), “O galo" (p. 45) e "Carta à irmã" (p. 85-7); ou episódios comuns, como o esquecimento de alguns pertences no trem, relatado no fragmento "Contratempo em Haia" (p. 55), descrito a seguir:

Ia de Amsterdam para Antuérpia. O condutor, ao picotar seu bilhete, disselhe alguma coisa em holandês.

- Não entendo.

Uma jovem, sentada à sua frente, serviu-lhe de intérprete: aquele trem não ia a Antuérpia, era preciso fazer baldeação em Haia ou Rotterdam. Preferível em Haia. E pôs-se a conversar. [...] E, de repente, a moça perguntou:

- Não vai saltar? Estamos em Haia.

Despediram-se apressadamente, o homem abriu a porta, desceu. Mal pusera os pés na plataforma, o trem partiu. Ocorreu-lhe, então, que deixara na rede uma reprodução de girassóis de Van Gogh, e o sobretudo, com as rápidas notas de viagem, óculos, caneta, luvas, cachecol, um pente e um sanduíche.

Foi ao departamento de Informações [...]

- Fique sossegado. (A funcionária sorria) Encontraram tudo.

[...] Em Dordrecht, onde chegará às 19h12, um funcionário irá entregar-lhe o sobretudo e os outros objetos.

$[\ldots]$

Ao chegar a Dordrecht, um homem ia saindo de um quiosque, com o seu sobretudo e os girassóis de Van Gogh (LINS, 1980, p. 55).

Se fizermos uma incursão pelo livro Chão de França (1935), de Ribeiro Couto (18981963), podemos observar que o narrador-viajante faz os registros de suas viagens em forma de fragmentos não nomeados e não datados. Ele chama atenção por sua maneira de sobrepor o solo físico ao intelectual em sua busca pelo "já conhecido e amado" (NITRINI, 1998, p. 54). Assim, no Capítulo VI, "Em Grenoble, com a lembrança de Stendhal”, o leitor pode desfrutar as sensações do narrador-viajante imerso na vida desse escritor:

Estas mesmas serras cobertas de neve, nos píncaros próximos, Stendhal olhou muitas vezes, cheio do tédio de se sentir prisioneiro da família - o velho Querubim Beyle, pai somítego; a tia Serafina, rabujenta; o avô Henry Gagnon, doutor em medicina [...] Detalhes da infância de Stendhal, cenas, acontecimentos, tudo sobrenada na minha memória e se confunde.

As largas ruas arborizadas, por onde se movimentam bandos de turistas, não dão aos meus olhos a imagem da Grenoble que desejo. Quero a outra, antiga, aborrecida, com ruelas estreitas. A rua dos Velhos Jesuítas, onde morava Stendhal. Onde será?

Place Grenette. Tiro do bolso o primeiro volume da Vie de Henri Brulard (edição de Le Divan) e procuro os desenhos que Stendhal teve a paciência minuciosa de fazer, para reconstruir melhor os fatos da infância. Aqui está, na página 44, a Place Grenette. 
$[\ldots]$

Eis a casa do velho Henry Gagnon. Aqui, ao menos, o pequeno Stendhal era feliz, porque o avô lhe falava dos versos de Horácio e do espírito de Voltaire. Daqui Stendhal podia ver, na Place Grenette, os soldados da Revolução que levavam um homem preso, ou aquela mulher do povo, que ele nunca esqueceu, exclamando: "Eu me revolto! Eu me revolto! Como uma louca, ou uma bêbada... (COUTO, 1935, p. 51-53)

Em Marinheiro de primeira viagem, Osman Lins não viaja para reviver uma experiência intelectual que busque o passado; em seus relatos, ele "traz os objetos de sua busca para a realidade presente" (NITRINI, 1998, p. 59), e, ao fazê-lo, estes são imantados pelo seu amplo repertório poético-intelectual. Para exemplificar, destacamos alguns fragmentos que julgamos representativos desse diálogo poético e cultural: "Dos sermões e de sua eficácia”, “A moça”, "Moça olhando Van Gogh”, "Canção", "Ulisses”, "Na Plaza Del Potro".

No fragmento "Dos sermões e de sua eficácia" (LINS, 1980, p. 9), questões filosóficas e literárias entrelaçam-se. O narrador conta a visita do "viajante" a uma igreja. Em meio às impressões do momento, vividas no templo, misturam-se as referências à fórmula cogito ergo sum, do filósofo René Descartes (1596-1650), com a Primeira Epístola do apóstolo Paulo aos coríntios, que exprimem um momento reflexivo-existencial do autor-personagem, como podemos conferir:

"E ainda que eu tivesse o dom da profecia e conhecesse todos os mistérios e
toda a ciência, e tivesse toda a fé, até a ponto de transportar montanhas, se
não tiver a caridade, não sou nada". Este era o tema do sermão, que o
estrangeiro, afastado do pequeno e silencioso rebanho, aglomerado nos
primeiros bancos, ouvia edificado. De súbito, no auge da edificação, sentiu
uma ligeira tontura e saiu para jantar. Soprava um vento gélido e insistente.
Nas ruas, todas desertas e irreconhecíveis, brilhavam algumas vidraças.
Escutava o rumor dos próprios passos. [...]. Menos esperava, viu-se de novo
em frente à catedral. Abriu-se a terra: a capa esvoaçando ao vento e bêbado,
tal esses personagens de Dostoievski, que aparecem no meio de uma ponte,
em pleno nevoeiro e dizem uma porção de coisas imprevistas, o clochard
avançou e pediu uma esmola. Recusou-a. E logo, lembrando-se de Paulo e
da Primeira Epístola aos Coríntios, começou novamente a buscar o seu
caminho, dizendo: "Nada sou, nada sou..." Ao que replicava,
cartesianamente, um demônio invisivel: "Falso. Tens fome e estás perdido.
Logo, és" (id., ibid., p. 9; grifos nossos).

A preocupação central das reflexões filosóficas de Descartes, iniciador da filosofia moderna, diz respeito ao conhecimento. Baseado nisso, o filósofo procura provar a existência do próprio eu (que duvida) e de Deus. Ele buscava conhecer o mundo e a vida por meio de leis comprovadas pela razão, porque, segundo ele, o homem pode, por sua luz natural, 
conhecer o real. Em sua busca, ele desenvolveu três argumentos, em etapas que vão se intensificando: (a) a ilusão dos sentidos, (b) do sonho, (c) e do "gênio maligno" (dúvida hiperbólica). Esse último argumento radicaliza a dúvida metódica, e é essa articulação cartesiana da possibilidade de existência do gênio enganador que Osman Lins associa à experiência do viajante que sentiu uma tontura e resolveu retirar-se para comer. Quando "menos esperava, viu-se de novo em frente à catedral".

O filósofo francês desenvolve a hipótese de que um Deus que tudo criou, a começar de si próprio, possa tê-lo criado acreditando na existência de todas as coisas, até mesmo nas verdades matemáticas, sem que tudo isso fosse verdadeiro. De acordo com a análise de Descartes, porém, se é impossível acreditar que Deus, um Ser bom e perfeito, faça isso com suas criaturas, mas, supondo que haja o engano, "que há não um verdadeiro Deus, que é a soberana fonte da verdade, mas certo gênio maligno, não menos ardiloso e enganador do que poderoso, que empregou toda a sua indústria em enganar-me" (DESCARTES, 1973, p. 96). Esse gênio seria mais poderoso que nós e se comprazeria em mostrar-nos como certo, algo que é errado. Esse pode parecer um raciocínio sem propósito, mas seu caráter é parte do método de Descartes, além de ser provisório. A dúvida tem a finalidade de conduzir o filósofo a um ponto fixo (arquimediano), e, ao intensificar-se a dúvida, o que se revela é a certeza da existência do próprio pensamento: "eu penso, logo existo" (id., ibid., p. 54), ou eu sou "uma coisa pensante". E, mesmo que um demônio ou gênio maligno me engane, ou que minhas idéias não sejam certas, é preciso que eu exista. Portanto, é no ser humano que se funda a certeza da própria existência e toda a estrutura do pensamento filosófico. Com esse argumento, ele estabelece as bases seguras para a construção do "edifício do conhecimento".

Assim, o filósofo afirma a possibilidade da ciência, isto é, do conhecimento verdadeiro, no sujeito (subjetividade), e que a Razão é confiável, no conhecimento de si e do mundo. Em Marinheiro de primeira viagem, inversamente, o narrador destaca o domínio que (a) o corpo e (b) a insegurança exercem sobre o viajante. Essas "fragilidades" transformam-se no ponto de apoio em que um "demônio invisível" se sustenta para dar a certeza ao viajante da existência de si e do mundo. A falta de alimento e a sensação de estar perdido destacam a fraqueza do ser humano, mas é de sua fragilidade que surge a certeza da própria existência. $\mathrm{O}$ “demônio invisível” faz com que ele lembre: “Tens fome e estás perdido". "Logo és".

No fragmento “A moça” (p. 10-1), o destaque se dá, na associação de obras de PierreAugust Renoir (1841-1919) e Vincent Willem van Gogh (1853-1890), ao relato de uma experiência do viajante, num trem que vai para Vierzon. Ele descreve uma passageira que se 
sentou à sua frente. A imagem da moça é referenciada aos quadros do pintor impressionista, La fillete à la gerbe ( ) e A leitora ( ), mas este segundo quadro não aparece nomeado pelo autor. Todas as evidências descritivas apontam, porém, para essa estratégia utilizada por Osman Lins. Ele recorre, nessa parte da narrativa, às pinturas de Renoir, como um decalque. Como se os quadros estivessem por baixo de sua escrita, e ele fosse contornando os quadros com sua narrativa, que ora tem um determinado aspecto posto em relevância, ora outro. Se ele fosse um desenhista, o lápis calcaria um pouco mais aqui, outro acolá, mas, como se trata de um escritor, os decalques e destaques são as palavras.

$\mathrm{O}$ viajante observa uma passageira que se senta à sua frente, à "esquerda, na janela oposta", primeiramente ela faz com que se lembre de um dos quadros do pintor holandês, $O$ escolar (Gamin au Képi), como podemos conferir:

Há, em seu perfil, no pontudo nariz, nos lábios grossos, qualquer coisa do Gamin au Képi. Também seu queixo, como no quadro de Vincent Van Gogh, era pesado. E havia ainda, entre ela e o modelo que o seu rosto evocava, uma relação que só mais tarde viria a ser surpreendida: em ambos o peso do queixo era atenuado por um reflexo verde, cor da sua blusa, que no triste menino de Vincent Van Gogh é azul (LINS, 1980, p. 10; grifos nossos nas duas ocorrências do nome de Van Gogh). 
O escolar, de van Gogh

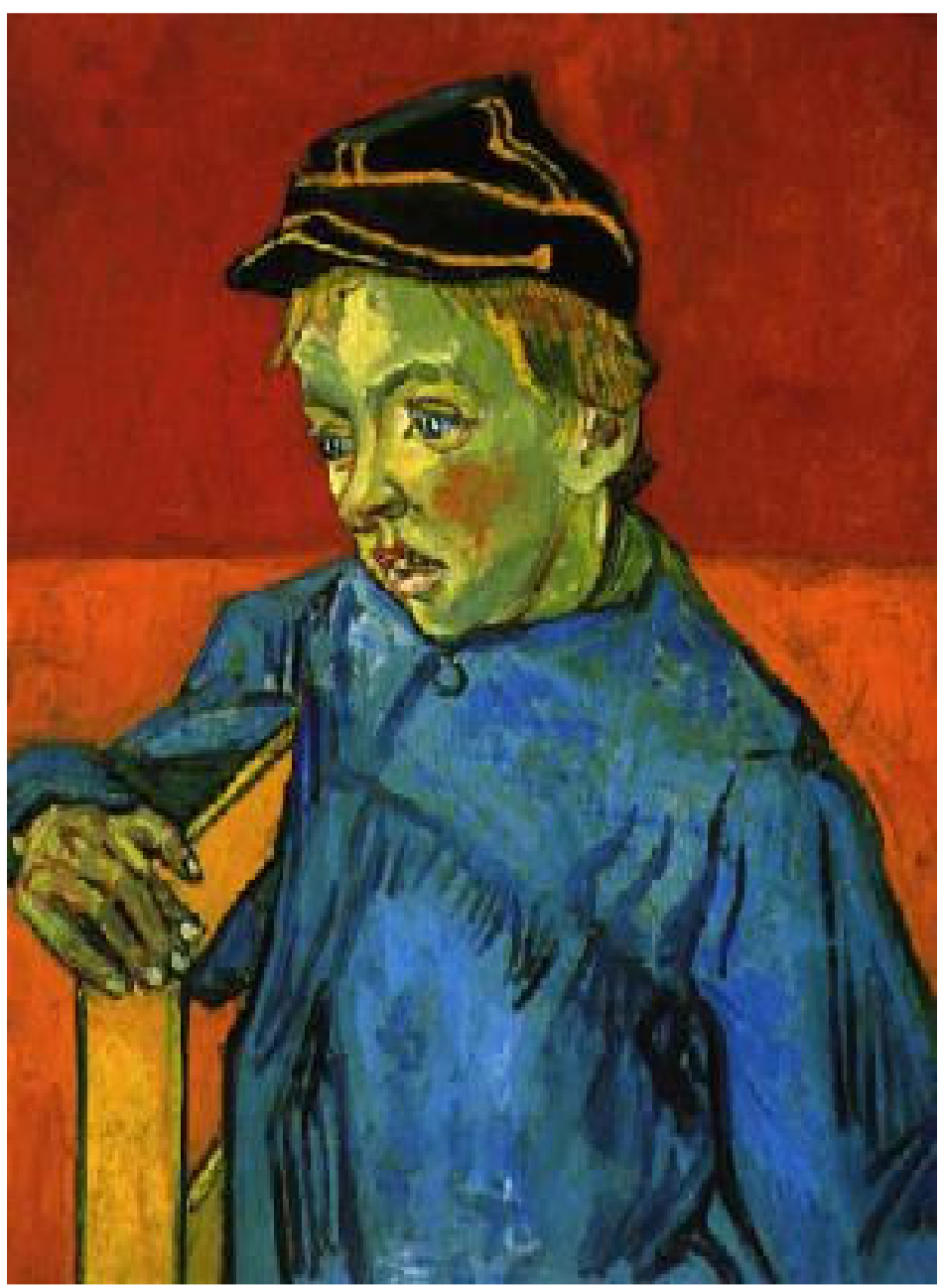

Talvez pelo fato de não ter visto esse quadro na França, mas sim, possivelmente, algum tempo depois, aqui no Brasil, no Museu de Arte de São Paulo (Masp) ${ }^{6}$, ele pôde perceber que a roupa do jovem pintado pelo artista holandês era azul e a da jovem observada no trem era verde.

Logo em seguida, ele comenta que a jovem o faz lembrar não as pinturas de Van Gogh, mas as de Renoir, e que tem a sensação de estar em frente ao quadro La fillete à la gerbe $^{7}$, em que o pintor impressionista retrata uma menina de 6 ou 7 anos, com os cabelos cor de mel, que caem sobre a testa, sentada e rodeada por plantas miúdas, por uma espécie de guirlanda, como podemos verificar na imagem abaixo.

\footnotetext{
${ }^{6} \mathrm{O}$ escolar, de Vincent van Gogh, óleo sobre tela, 63 x $54 \mathrm{~cm}$. Proveniente da Galeria H. Tannhäuser, Munique; depois passou para Max Meirowsky, em Berlim. Desde 1952, pertence ao Masp.

${ }^{7}$ Uma reprodução de La fillette à la gerbe (Menina com espigas), óleo sobre tela, 56 x $54 \mathrm{~cm}$, de A. Renoir também pertencente ao acervo do Masp desde 1952.
} 
A menina com espigas, de Renoir

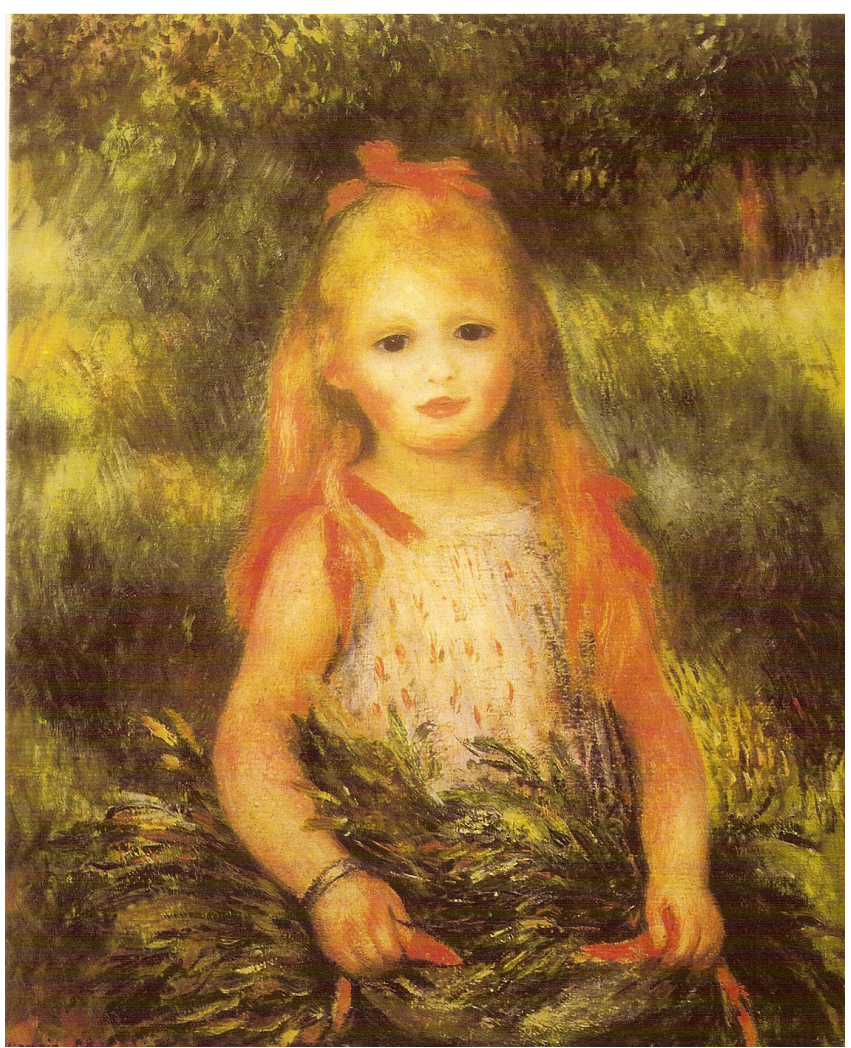

Porém ele conclui:

Se havia, em seus traços, semelhança com Le collégien, nem assim era ao mundo de Van Gogh que ela pertencia - e sim, pelos cabelos cor de mel, em desalinho, caindo sobre a testa, pela finura e transparência da pele, por qualquer coisa de odoroso e frutal que a envolvia, ao de Renoir. La fillete à la gerbe, aos 17 anos, e de olhos azuis (LINS, 1980, p. 10; grifo nosso no nome de Van Gogh).

A viagem prossegue, e, em seguida, o ângulo e a confluência da luz em que a moça se encontrava remetem o viajante à lembrança de um outro quadro, não declarado no texto, cuja descrição lembra $A$ leitora ${ }^{8}$, uma das pinturas mais luminosas de Renoir, segundo a crítica. Nessa obra, o pintor retrata uma jovem que lê com a cabeça levemente inclinada: às suas costas, a luz atravessa pela janela, envolve-a e destaca a alegria que se origina de sua leitura. A semelhança entre a cena pintada por Renoir e a da moça que está sentada à sua frente é

\footnotetext{
${ }^{8}$ A leitora, quadro de Renoir, pertence ao acervo do Museu do Louvre.
} 
perfeita. Observemos como ele descreve e a semelhança com a ilustração, colocada logo em seguida:

A cabeça inclinada, lia com atenção. O sol iluminava em cheio as páginas do livro, suas mãos, parte da blusa, o rosto, a cabeleira. Ele contemplava, orlada por um fio de luz que era o gume daquele perfil, a face sombreada; esta, porém, parecia esplendente como se fora de vidro, recortada contra a janela do vagão, através da qual ele via o campo nu, ensolarado e frio, com seus ramos secos (id., ibid., 1963, p. 10).

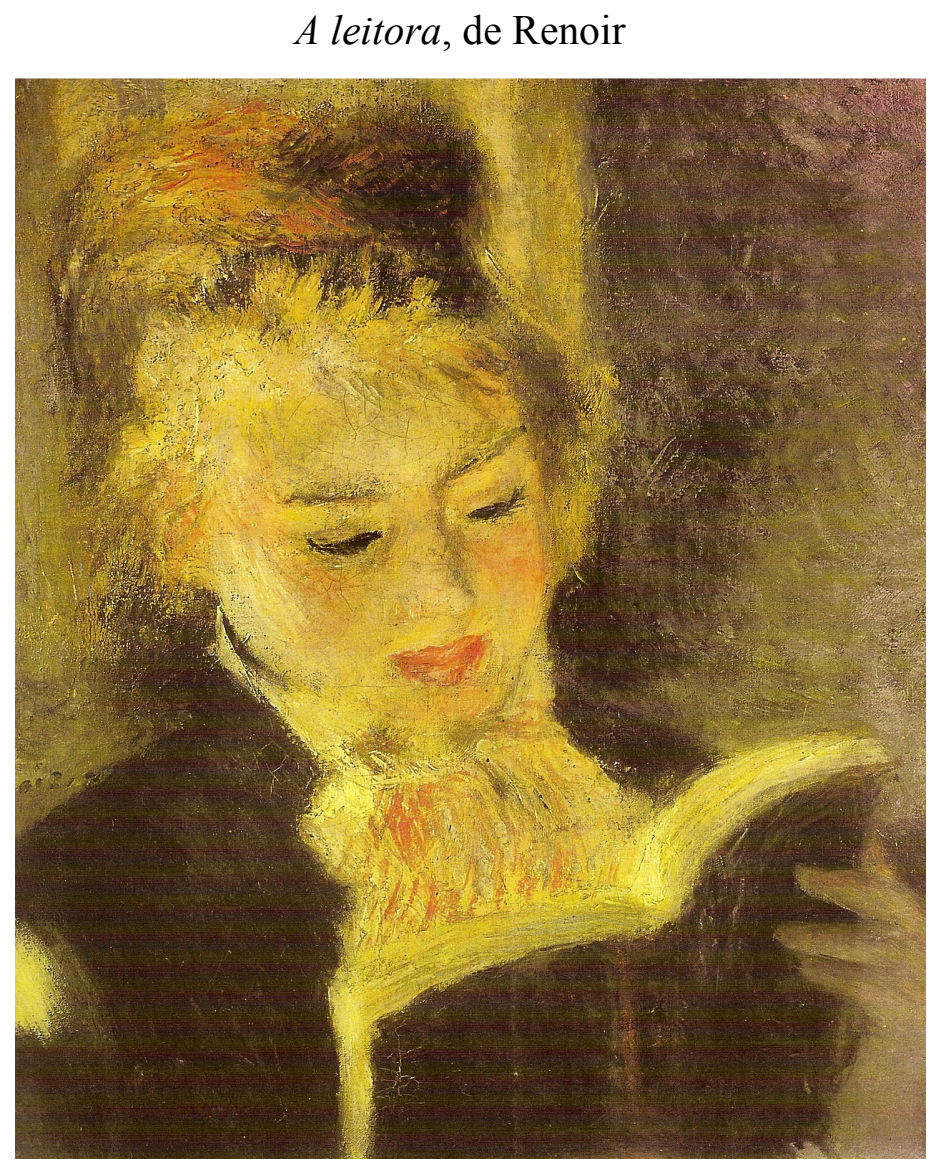

Em seguida, ele faz algumas reflexões sobre os quadros dos pintores pré-renascentistas e suas madonas, e continua o desenrolar da narração. $\mathrm{O}$ trem pára, e a moça prepara-se para descer, momento em que a harmonia perfeita entre a cena observada de perto e as pinturas lembradas se rompe:

[...] o trem parou numa estação cujo nome era Marmagne - e a moça, fechando seu livro, levantou-se. Sem a passagem ao fundo, sem a luz do sol nos seus cabelos, perdera o encanto. Nada apresentava de mágico, de transcendente. E mesmo seus liames com Renoir e Van Gogh pareceram 
falsos ou, pelo menos, transitórios, rompidos para sempre (LINS, 1980, p. 11; grifo nosso).

No fragmento "Moça olhando Van Gogh" (p. 54), obras de arte pictóricas e literárias são projetadas sobre o real ao narrar a observação de uma jovem que contempla as obras de Van Gogh, Milet, Seurat, Cézanne, durante visita ao Museu Municipal. O que chama a atenção é a menção feita à escritora Mary Shelley (1797-1851), que inovou o conto fantástico e marcou a primeira metade do século XIX, com a primeira obra literária de ficção científica, Frankenstein, ou o Prometeu moderno (1818).

O diálogo intertextual com a escritora inglesa aparece em "Moça olhando Van Gogh", tanto no que concerne às características físicas de Shelley, quanto a seu trabalho literário. A jovem visitante do museu carregava na mão um "volume de Shelley", como podemos acompanhar na passagem abaixo:

\footnotetext{
Sapatos baixos, calças azuis, casaco de lã negro. Bolsa de vime. Um chapeuzinho branco, cônico, trançado. Na mão, um volume de Shelley. No Museu Municipal, vai de quadro em quadro, de sala em sala, senta-se, levanta-se. Contemplação solitária e evidentemente encantada. Até então, vira reproduções ou quadros isolados. Agora, como num gráfico, vê a trajetória do artista, sua busca, os espectros de Milet, Seurat, Cézanne. Vai de quadro em sala, senta-se, levanta-se. O chapeuzinho cônico. (id., ibid., p. 54, grifo nosso).
}

Aqui, as mãos da jovem visitante são descritas: "Estudo de mãos. (Suas mãos são finas). Gestos. (Os seus são lentos.) Uma linha estridente, outra que se perde, frágil, num pulso nu" (id., ibid., p. 54). Talvez, nada mais significativo do que uma descrição, se não fossem as mãos da própria Mary Shelley, extremamente delicadas, com os dedos delgados retratadas na pintura baixo, como podemos conferir: 
Pintura de Mary shelley

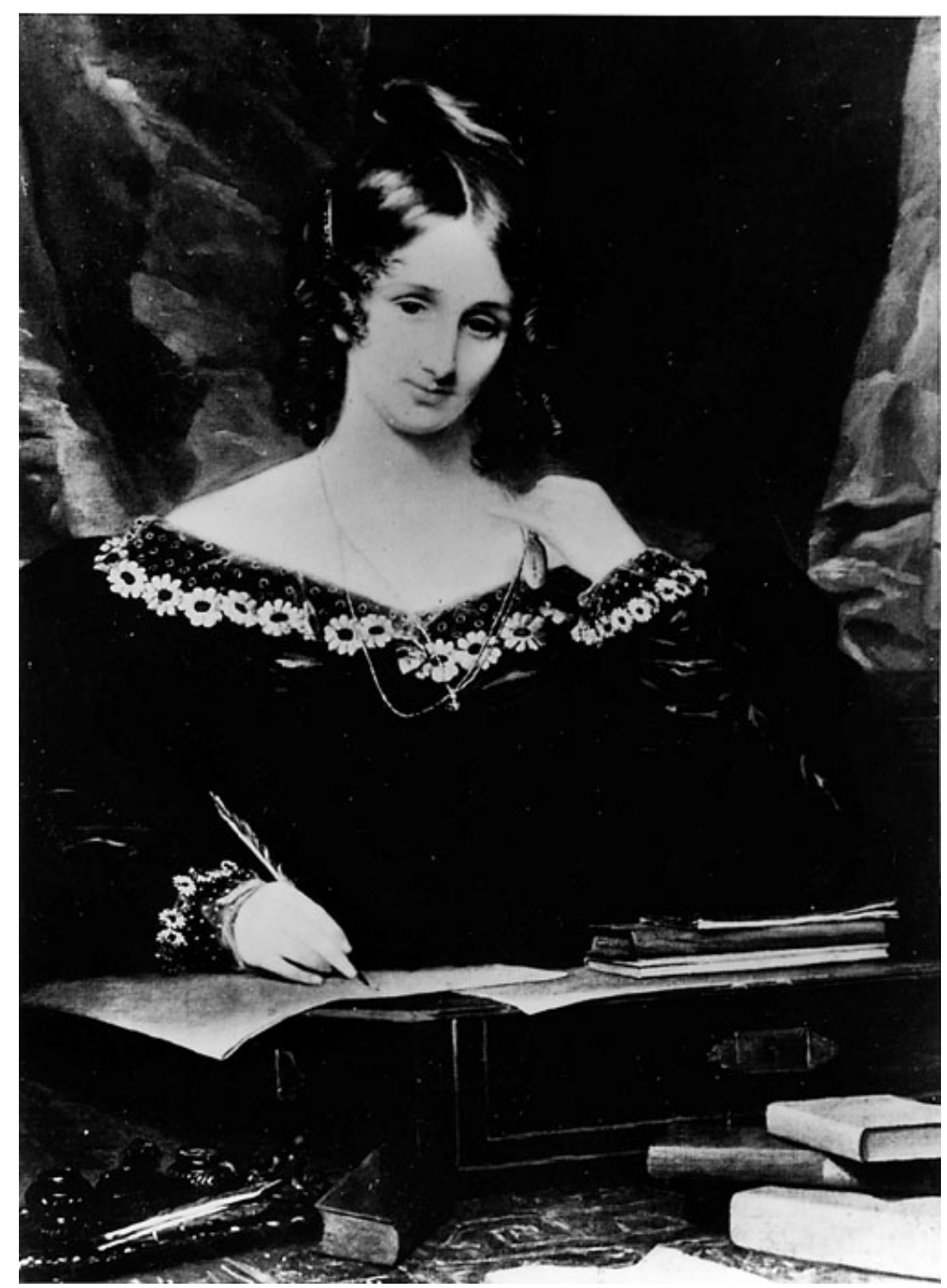

Em seguida, o que chama a atenção na narrativa é uma palavra, aparentemente solta, "Metamorfoses", que leva o leitor a um dos temas desenvolvidos por Shelley, que origina uma estranha criatura. A jovem escritora conta a história do médico, o dr. Viktor Frankenstein, que, graças aos ensinamentos de sábios alquimistas, cria, a partir de modificações e metamorfoses de despojos humanos, uma criatura que viria mais tarde a receber o mesmo nome de seu "criador", o monstro Frankenstein.

Placidez e crispação. Busca. Também ela, na vida... Gestos. Em sombras e traços. [...] Metamorfoses. O ir da sombra para a claridade, nesta arte que 
aos poucos amanhece, com a luz dos girassóis e dos trigais em fogo. Amarelo, luz, laranja, cadeira vazia. (id., ibid., p. 54, grifos nossos). [...] Lentamente, afasta-se. Calças azuis, casaco de lã. Vai envolvida em céus iluminados, trigais e girassóis, barcos, árvores flamantes.

O narrador finaliza o fragmento com um clima próprio do livro de Mary Shelley, como podemos conferir:

Ecoam docemente, seus passos miúdos, nas largas tábuas do chão. [...] Admira-se de que, lá fora, Amsterdam esteja fria e que seja tão pálido seu ar. Lerá talvez em Shelley: "Quando as candeias se apagam, morre a luz desfeita em pó”. Não totalmente. Em parte, apenas. Muito ficará, numa clareira, lembrança cintilante (id., ibid., p. 54, grifos nossos).

Num outro fragmento, "Canção" (p. 79), o narrador relata detalhes da visita do viajante à Galleria degli Uffizi", em Florença, onde tem acesso às pinturas das "grandes" vênus e madonas que marcaram a tradição pictórica. $\mathrm{O}$ registro é pleno da poeticidade que envolve o quadro "A Batalha de San Romano" (c. 1450), em que Uccello explora ao máximo a técnica da perspectiva na pintura dos cavalos. Essa experiência também desencadeia um entrecruzamento da pintura dos quadros e o real, como se o viajante entrasse no quadro, a ele se incorporasse e penetrasse numa outra dimensão, uma terceira via, a do universo artístico, que tem vida própria. Uma região em que impera o imaginário e o sonho, mas desencadeados pela obra de arte real, como podemos constatar:

Galeria dei Uffizi. A Anunciação, de Da Vinci. La Pietá, de Perugino. A Coroação da Virgem, de Fra Angelico, [...] A Batalha, de Uccello, com seus potentes e oníricos cavalos. Monta num cavalo azul, atravessa as salas, compassadamente. Madonas seguem-no, a de Cimabue, a de Rafael, com seu cordeiro; e a Primavera, de Botticelli, em seu vestido florido; e sua Venus doentia; a rubicunda Vênus de Lorenzo di Credi; e também a Venus reclinada, de Tiziano, não menos adiposa, levanta-se e acompanha-o, com suprema indolência. Silenciosamente, sobem ao terraço do museu, contemplam a praça della Signoria. Carruagens paradas, cafés com flores e toalhas coloridas, gente, badalar de sinos. Quando os sinos param, escuta-se o rumor dos veículos e da água que tomba, com abundância, na Fonte de Netuno. Além, o Duomo, o Campanile, pequenas casas brancas, espalhadas nas colinas verdes, sob o sol de maio. O cavalo de Uccello sopra com energia. Agrupadas em torno de seus flancos, diante da paisagem, Vênus e Madonas põem-se a cantar uma canção que fala de vinhedos (LINS, 1980, p. 79, grifo nosso).

Em seguida, anexamos algumas imagens das obras de arte aqui relacionadas por Osman Lins, com o objetivo de facilitar a apreensão visual de todo o conjunto do relato que o autor nos propicia:

\footnotetext{
${ }^{9}$ Galleria degli Uffizi está situada no centro histórico da cidade de Florença. Ela abriga grande concentração de obras de arte e é considerada o berço do Renascimento italiano.
} 
A anunciação, de Da Vinci ${ }^{10}$

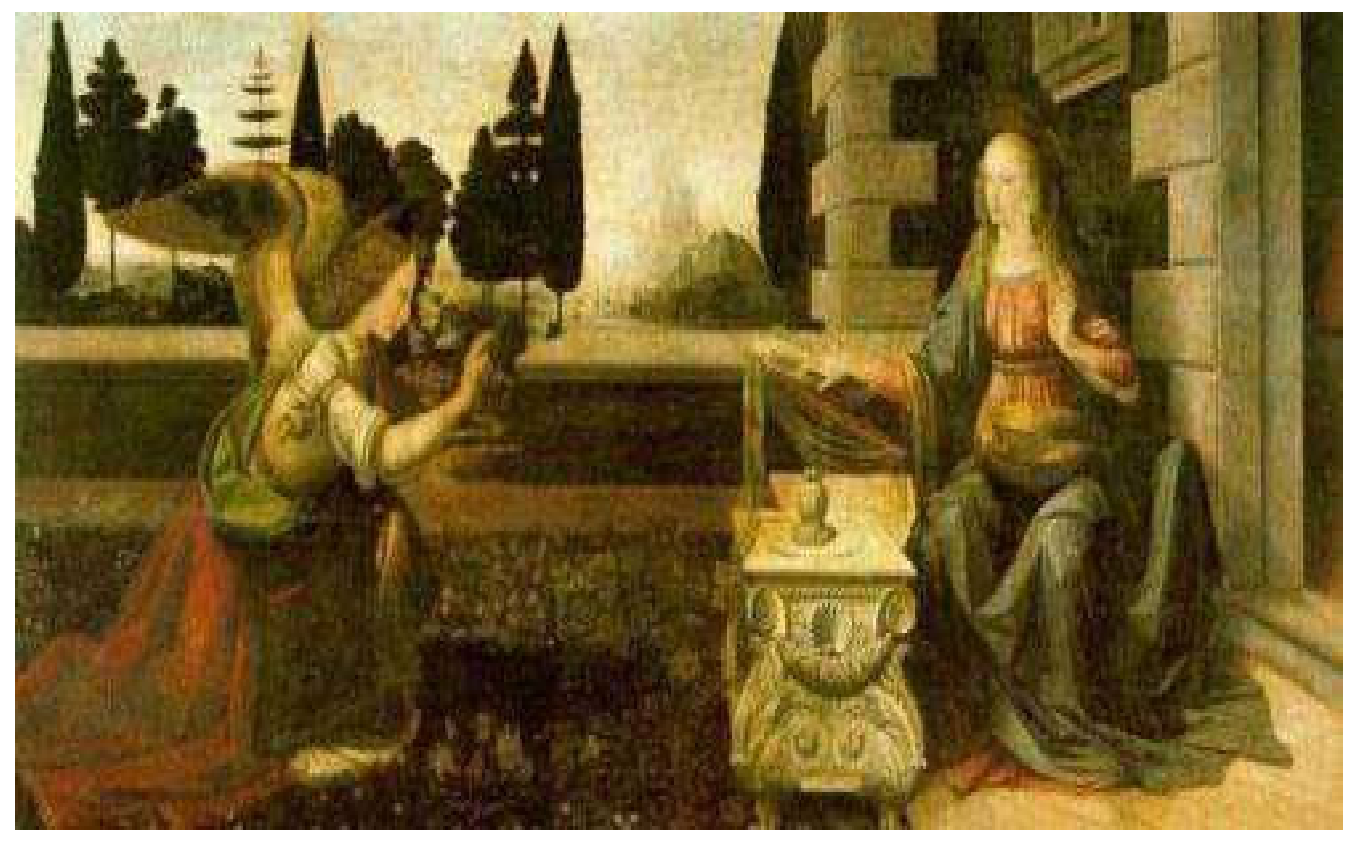

\footnotetext{
${ }^{10}$ Fonte: $\underline{\text { http://renascimento.clio.pro.br/artes.htm }}$
} 
La Pieta, de Perugino ${ }^{11}$

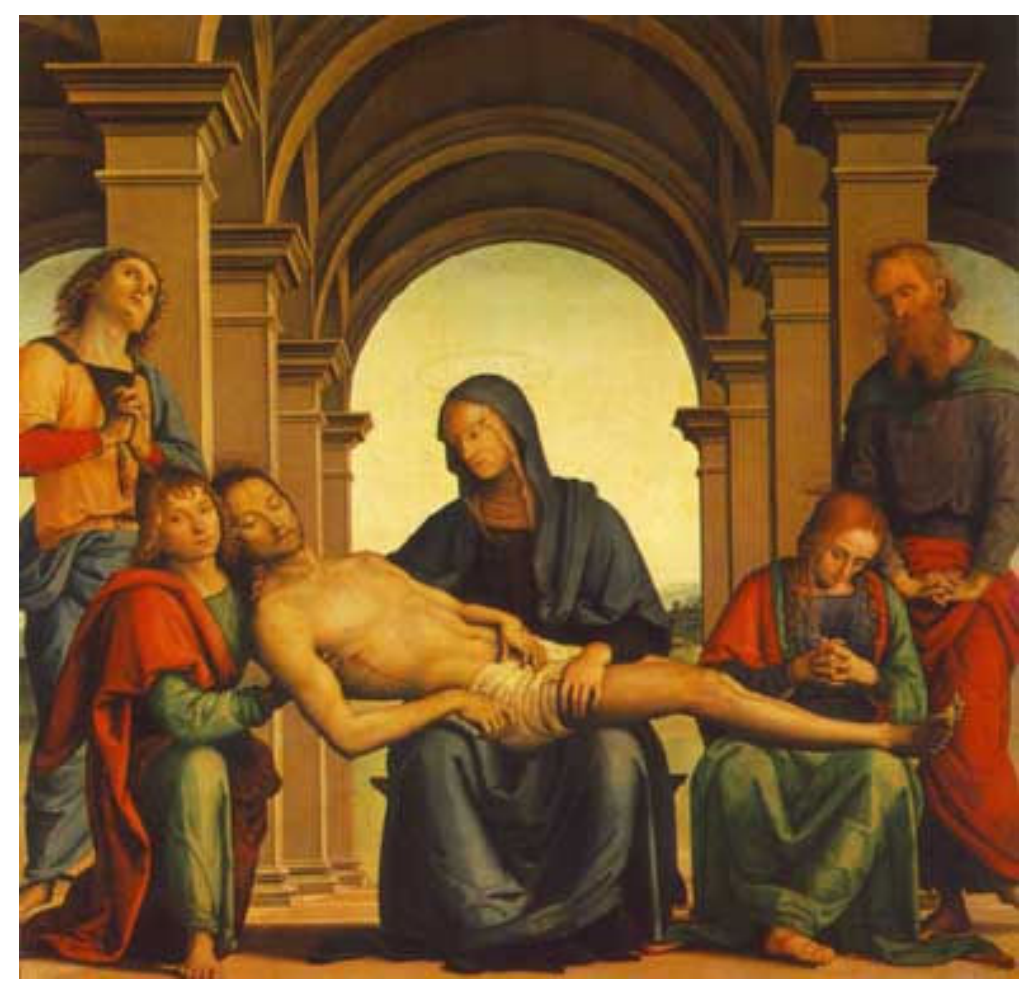

\footnotetext{
${ }^{11}$ Fonte: $\underline{\text { http://www.abcgallery.com/P/perugino/perugino15.html }}$
} 
A Batalha de San Romano, de Uccello ${ }^{12}$

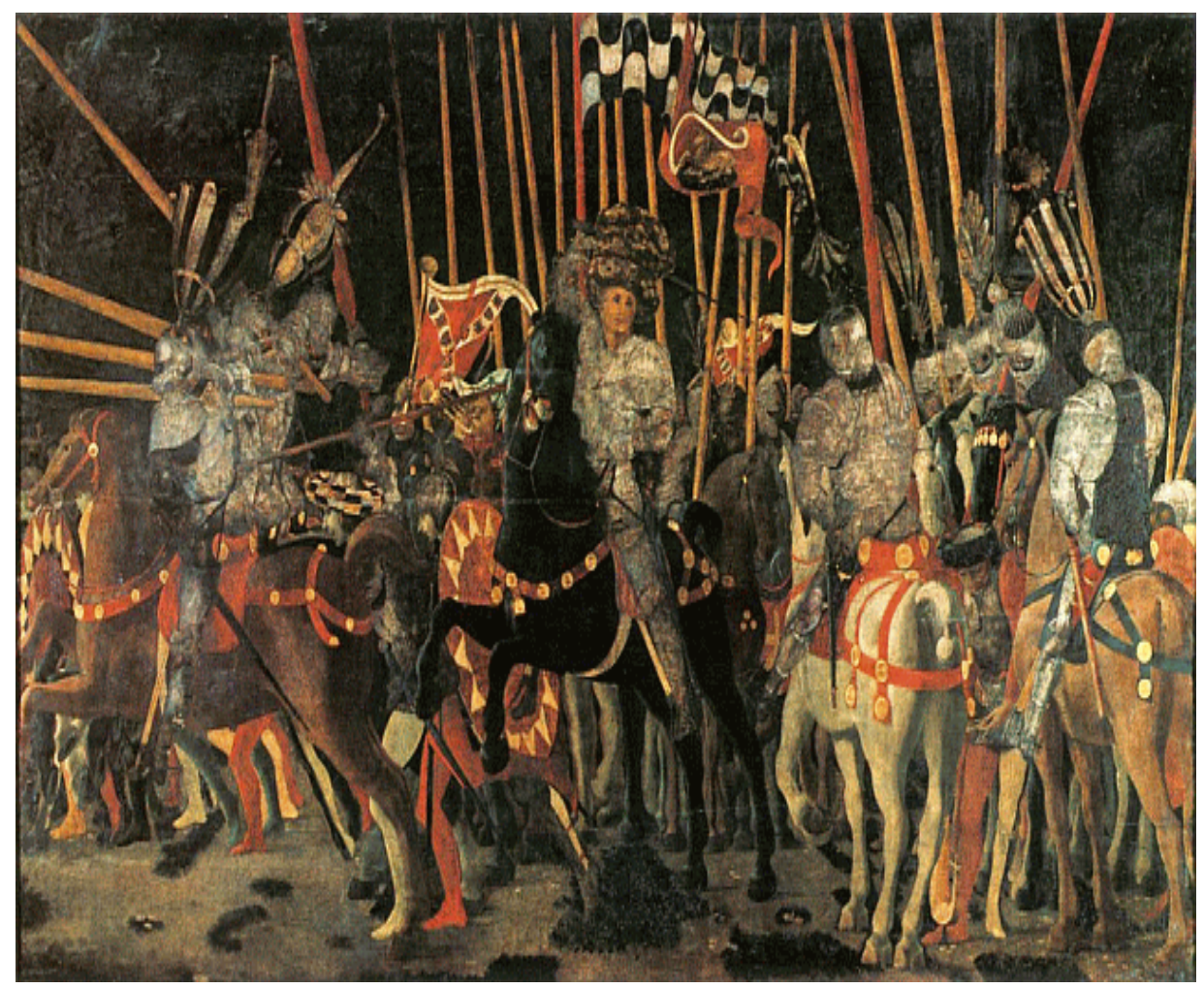

${ }^{12}$ Fonte: $\underline{\text { http://wabfrance.free.fr/rubrique.php3?id rubrique }=4}$ 
A Batalha de San Romano, de Uccello ${ }^{13}$

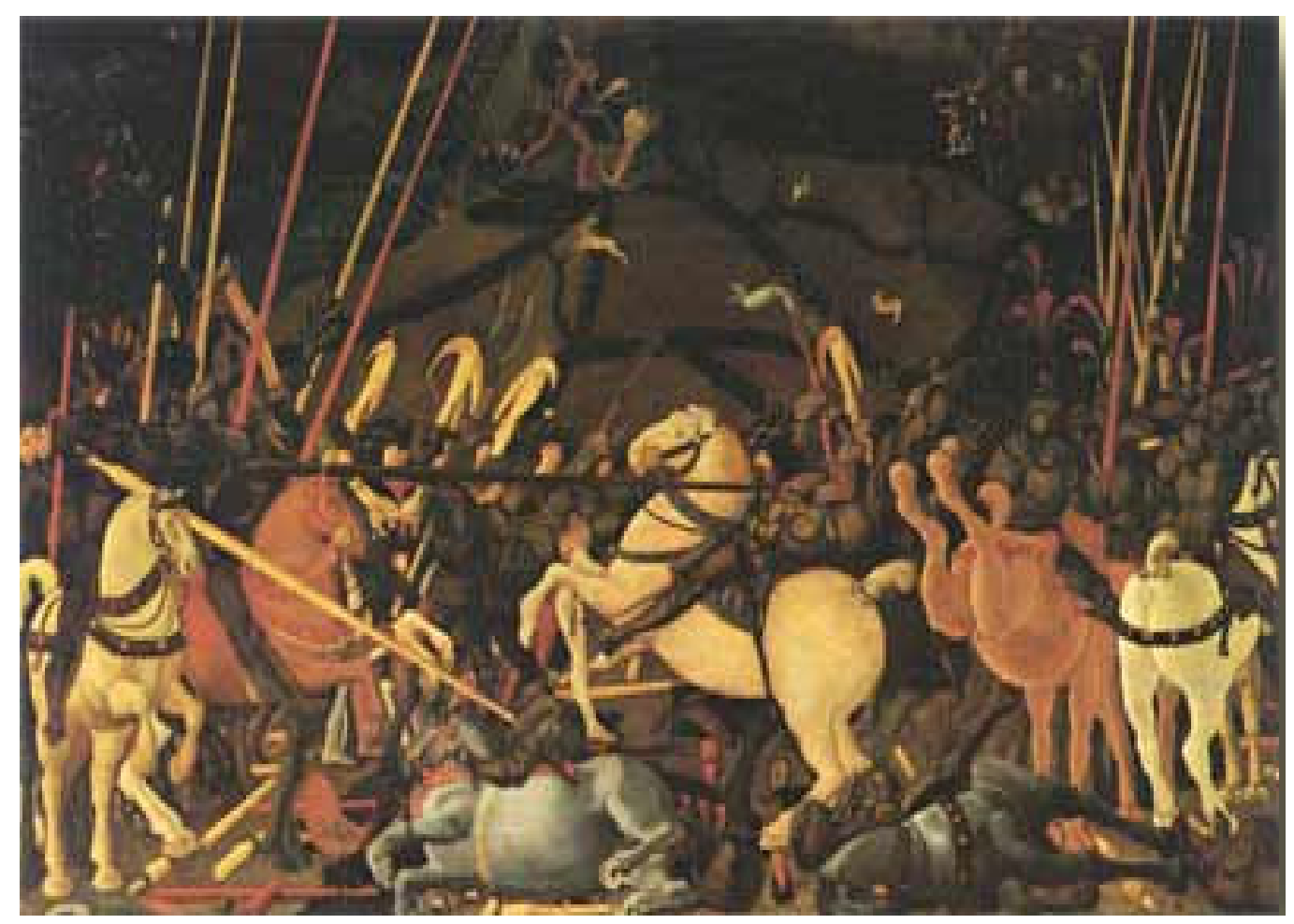

${ }^{13}$ Fonte: http://wabfrance.free.fr/rubrique.php3?id rubrique $=4$ 
Madona, de Cimabue ${ }^{14}$

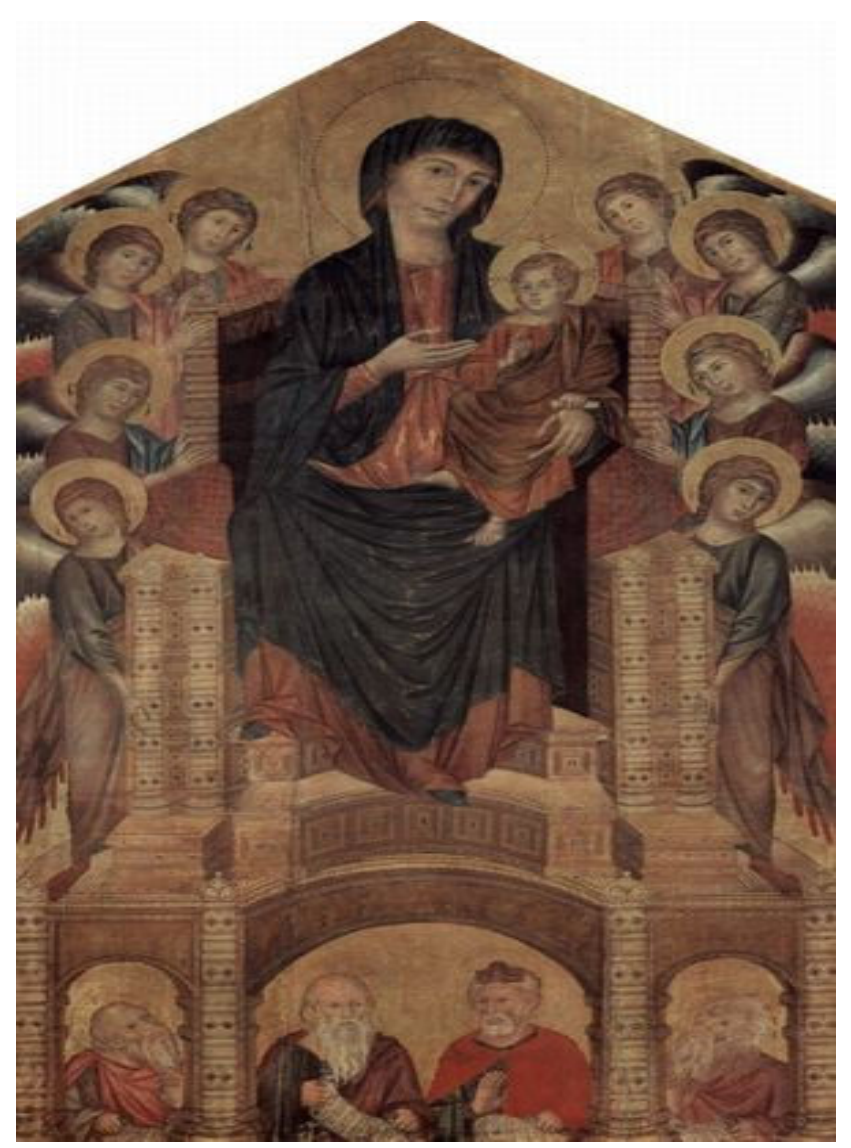

${ }^{14}$ Fonte: http://www.auladearte.com.br/historia da arte/images/gotico/cimabue05.jpg 
A primavera, de Botticelli ${ }^{15}$

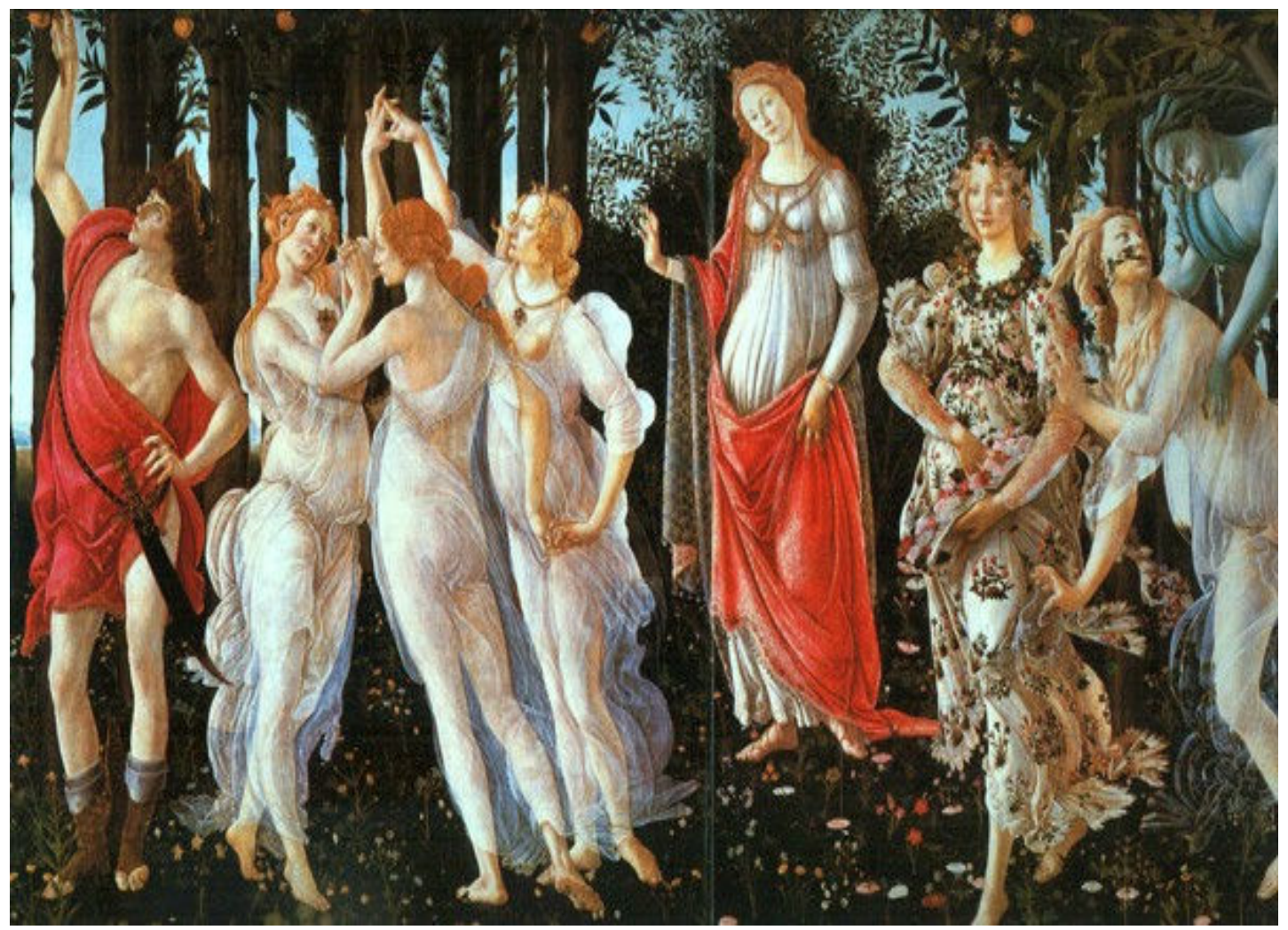

${ }^{15}$ Fonte: $\underline{\text { http://www.virtualuffizi.com/uffizi/img/8360.jpg }}$ 
Vênus, de Botticelli ${ }^{16}$

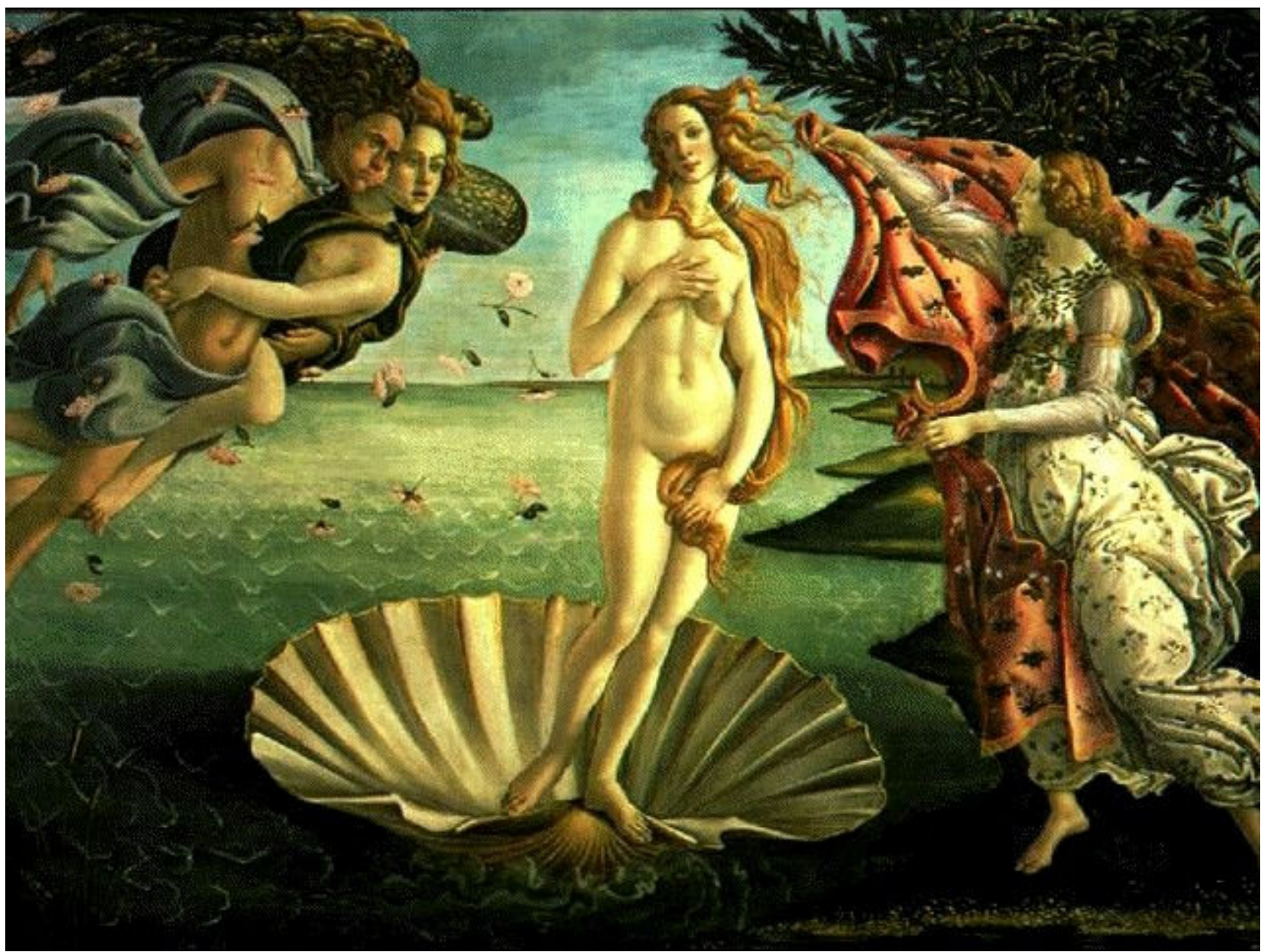

$\overline{{ }^{16} \text { Fonte: web.educastur.princast.es/.../afrodita.htm }}$ 
Vênus, de Lorenzo di Credi ${ }^{17}$

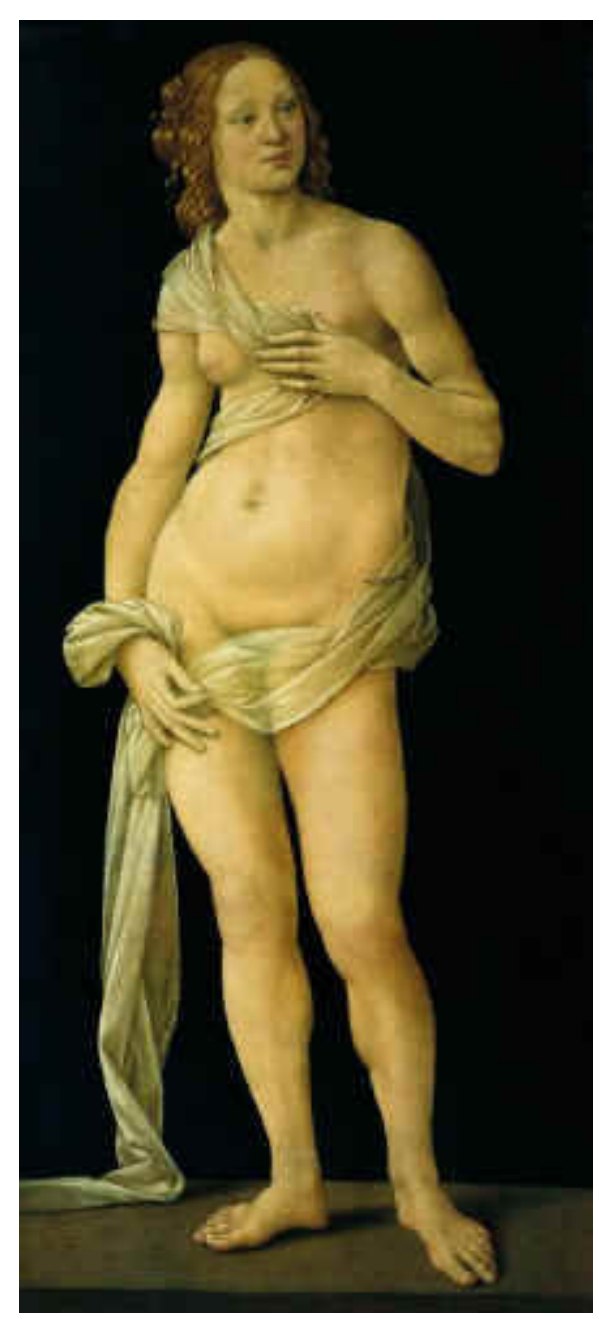

\footnotetext{
${ }^{17}$ Fonte: www.latribunedelart.com/Expositions 2003/Expo...
} 
Vênus, de Tiziano ${ }^{18}$

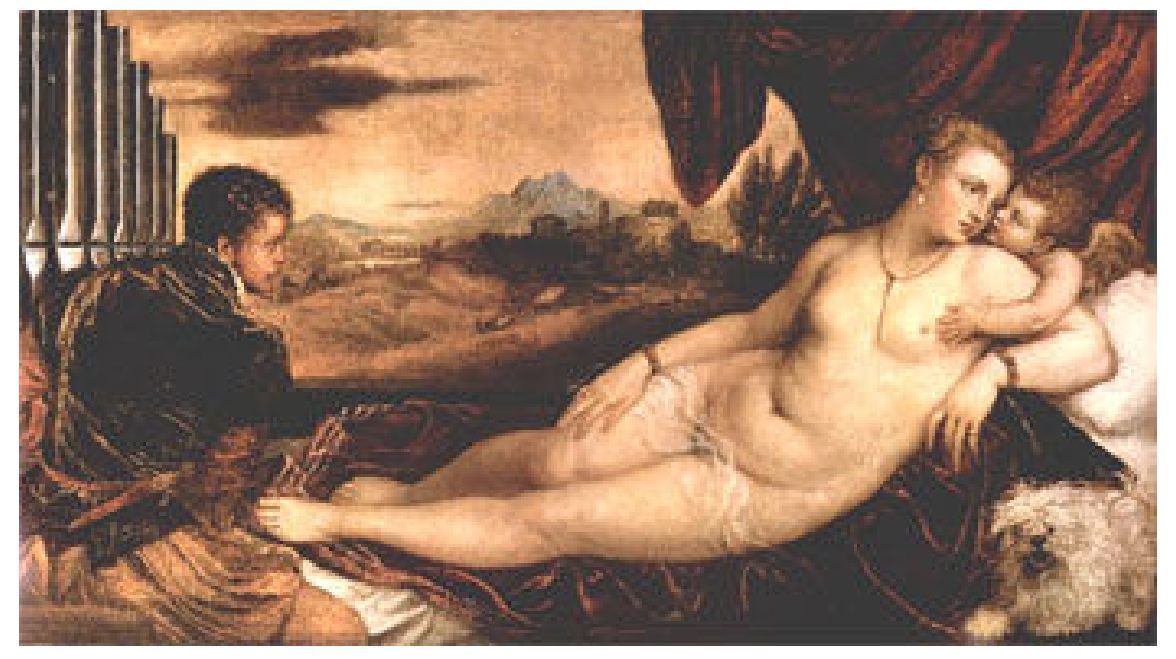

${ }^{18}$ Fonte: $\underline{\text { www.revistakatharsis.com/rev abr } 04 \text { sm pint } 0 . .}$ 
A coroação da virgem, de Fra Angélico ${ }^{19}$

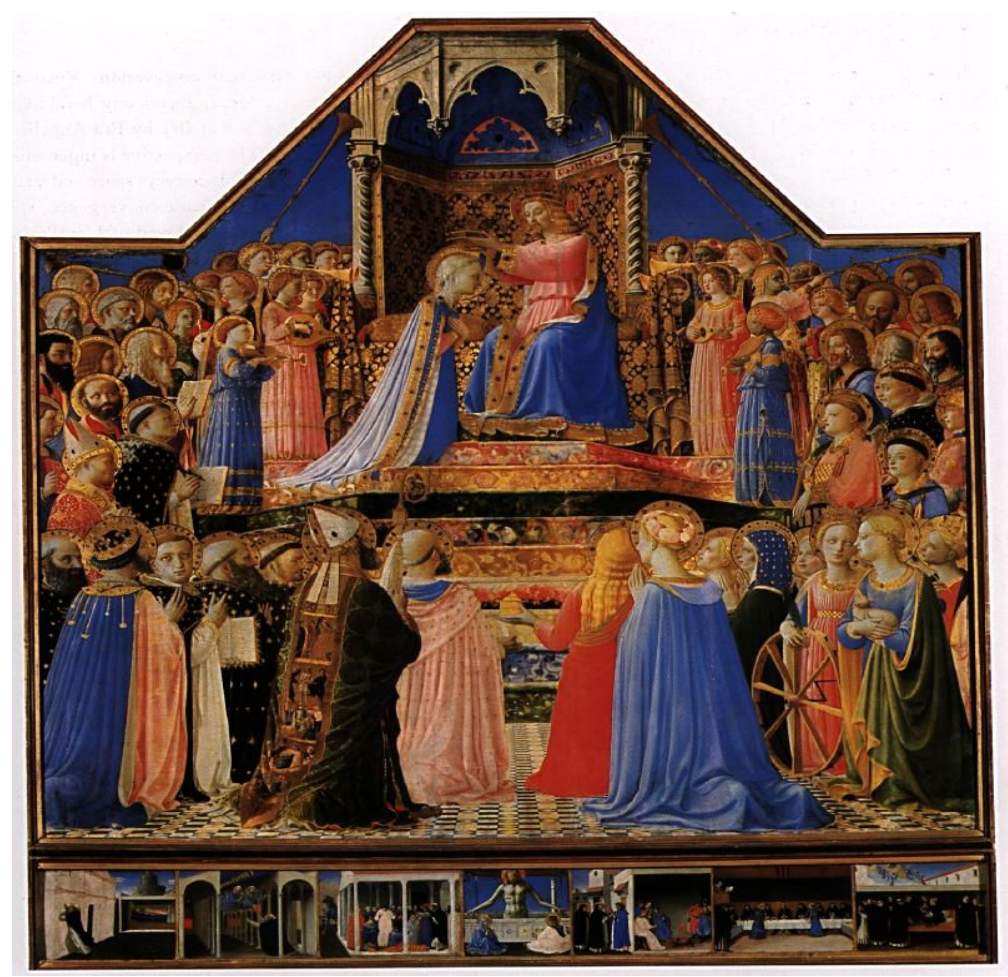

${ }^{19}$ Fonte: http://www.cs.dartmouth.edu/ wbc/Gowing/Fra-Angelico.jpg 
Agora, o destaque será o diálogo viagem-arte mediado pela literatura que se apresenta no fragmento intitulado "Ulisses" (p. 89-90), narrativa da visita do viajante à ilha de Capri, na Itália, em que se entrelaçam momentos de ficção e de realidade. Nessa passagem, a relação dialogal é com o Canto XII da Odisséia, de Homero, em que é narrado o episódio do Canto das Sereias. O lendário poeta grego conta que o herói Odisseu, após ter participado da guerra de Tróia, quer retornar a seu reino, à sua verde Ítaca, mas não consegue, pois desafiou Poseidon, o Rei dos Mares, furando o único olho de um de seus filhos, o ciclope Polifemo. Em razão disso, o Rei dos Mares castiga-o e impede-o de voltar, fazendo-o passar muitas agruras. Entre as dificuldades que Odisseu precisou enfrentar em sua viagem de retorno está a sedução provocada pelas sereias, cuja melodia encantava e arrastava para elas quem as escutasse. O herói toma a decisão de tapar as orelhas dos companheiros com cera para que eles não fiquem tentados, mas ordena que o amarrem ao mastro do navio, porque quer ter o prazer de ouvir o canto sedutor ${ }^{20}$.

\footnotetext{
${ }^{20}$ Homero, Odisséia, Canto XII, 158-200
}

Manda, em primeiro lugar, que as divinas Sereias, dotadas de voz maviosa, evitemos e o prado florido em que se acham. Somente a mim concedeu que as ouvisse; mas peço a vós todos que me amarreis com bem fortes calabres, porque permaneça junto do mastro, de pé, com possantes amarras seguro. $\mathrm{Se}$, por acaso, pedir ou ordenar que as amarras me soltem, mais fortes cordas, em torno do corpo, deveis apertar-me. [...] Uma rodela de cera cortei com meu bronze afiado, em pedacinhos, e pus-me a amassá-los nos dedos possantes. Amoleceu logo a cera, por causa da força empregada e do calor grande de Hélio, o senhor Hiperiônio esplendente. Sem exceção, depois disso, tapei os ouvidos dos sócios; as mãos e os pés, por sua vez, me amarraram na célere nave, em torno ao mastro, de pé, com possantes calabres seguro. Sentam-se logo, batendo com o remo nas ondas grisalhas. Mas, ao chegar à distância somente de grito da praia, com toda a força a remar, não passou nosso barco ligeiro despercebido às Sereias, de perto, que entoavam sonoras: "Vem para perto, famoso Odisseu, dos Aquivos orgulhoso, traz para cá teu navio, que possas o canto escutar-nos. Em nenhum tempo ninguém por aqui navegou em nau negra, sem nossa voz inefável ouvir, qual dos lábios nos soa”.

$[\ldots]$

Dessa maneira cantavam, belíssima. Mui desejoso de as escutar, fiz sinal com os olhos aos sócios que as cordas me relaxassem; mas eles remaram bem mais ardorosos. Alçam-se, então, Perimedes e Euríloco e deitam-me logo novos calabres, e os laços e as voltas mais firmes apertam. Mas, quando essa ilha, na viagem, deixamos ficar bem distante, sem mais ouvirmos a voz das Sereias e o canto mavioso, meus companheiros queridos tiraram depressa do ouvido a cera ali por mim posta e dos laços, por fim, me livraram. 
Esse episódio do Canto XII da Odisséia é astutamente incorporado por Osman Lins no fragmento "Ulisses" (LINS, 1980, p. 89-90) de Marinheiro de primeira viagem para descrever uma experiência do viajante durante seu passeio de barco à ilha de Capri. Essa região, que pertenceu ao mundo do herói Odisseu, foi um território de domínio dos gregos antigos, a Magna Grécia e o local de nascimento da ontologia, com Parmênides de Eléia.

Entre as muitas aproximações à história da antiga epopéia está o aparecimento de "uma ave estranha", que projeta "sua sombra augural" sobre a embarcação em que se encontrava o viajante. É importante lembrar que o olímpico Zeus apresentava-se, em algumas ocasiões, em forma de ave. Com certeza, para acompanhar de perto se suas ordens estavam sendo cumpridas e para garantir a volta de Odisseu a Ítaca. Observemos a ressonância da Odisséia, no "pequeno" fragmento osmaniano "Ulisses" (p. 89-90), como segue:

Está num barco que vai para Capri. Manhã esplêndida. Velas brancas e azuis oscilam na baía, sobre as águas verdes. As águas refletem o sol na grande marquise do porto. Os barcos não têm flâmulas nos mastros, nem bandeiras. Logo partem, singram o salso mar. Peixes de várias cores seguem o batel; $e$ uma ave estranha, voando entre o sol e a frágil embarcação, acompanha-a com a sua sombra augural, que pode significar, ao mesmo tempo, morte e proteção.

Muitos, indiferentes ao sol, ao vento, ao verde do mar e ao azul doce do céu, comem sanduíches com cerveja. Aos poucos, todos emudecem e entreolhamse, alguns têm olheiras, parecem aterrorizados. É quando vem o garçom trazendo uma bandeja cheia de pedaços de cera, com que arrolha os seus próprios ouvidos e os dos passageiros. Só então ocorre a Ulisses quanto perigo há nesta viagem. Que lhe sucederá se ouvir o canto das Sereias, que tentam os viajantes com a sua voz melodiosa, rodeadas de esqueletos humanos? Impávido, recusa a cera, sob os olhares atônitos dos companheiros. Querem amarrá-lo. Recusa-se também. E para mostrar como está imperturbável, pede por mímica uma limonada.

De súbito, aumentadas pelos autofalantes estereofônicos, ouve as temidas vozes das Sereias. "Desce e fica conosco. Agora conheceste as amplidões e sabes o que é ser feliz. Este é o teu destino, escutar as canções que poucos têm coragem de ouvir. Fica entre nós. Não voltes mais à mentira e ao silêncio, não voltes mais aos ruídos inúteis, só há uma verdade: esta verdade reside em nossa voz." Sereno, ficou onde estava, bebendo seu refrigerante. Uma parte dele (qual?) precipitou-se entre os passageiros, atirou-se ao mar, nadou para as Sereias. Cujas vozes morreram, abafadas pelo rumor das ondas. Garçom e passageiros sacudiram-no, lívidos. Ele tinha a garrafa espatifada entre os dedos (LINS, 1980, p. 89-90; grifos nossos).

Esse episódio do Canto das Sereias, amplamente discutido por T. W. Adorno e M. Horkheimer (1986), na Dialética do Esclarecimento, representa o impasse entre o mito e a razão. Nesse evento enfrentado pelo homérico Odisseu, que, ao passar pelo local onde habitam as encantadoras sereias, obriga "seus companheiros a remar com os ouvidos tapados, enquanto ele, solitário, com os ouvidos livres, preso ao mastro, escuta desesperado as vozes 
encantadoras do gozo recusado" (MATOS, 1999, p. 142). O "desejo representa uma espécie de resistência marginal e interrogativa com relação à racionalidade" (p. 142). Razão e desejo são duas possibilidades distintas que habitam o humano e que parecem nunca se conciliar: a "razão dominadora", tirânica, recusa a ameaça do desejo, que vem "perturbar a ordem da razão" (p. 142).

Como relata Osman Lins em seu "Ulisses", o viajante, ao ouvir o canto, não resistiu: uma parte dele "precipitou-se entre os passageiros, atirou-se ao mar, nadou para as Sereias". Mas a pergunta permanece: qual parte dele entregou-se, e qual permaneceu nele? A razão ou a paixão?

No fragmento "Na Plaza Del Potro" (LINS, 1980, p. 131), a relação dialogal é com a importante obra da literatura da Espanha Don Quixote de la Mancha (1605), escrita pelo romancista, dramaturgo e poeta espanhol Miguel de Cervantes Saavedra (1547-1616).

$\mathrm{O}$ viajante, em sua visita à antiga cidade espanhola de Córdova, chega à Plaza del Potro, situada na Rua do Potro, no bairro de mesmo nome, que "é ornada com uma fonte de quatro canos, tendo no centro um globo sobre o qual, três patas no ar, um potro não muito grande, de pedra, jamais se decide a descer e vir passear sobre as enormes lajes que ladrilham a praça” (p. 131).

Sob o olhar observador do personagem, ele vê, em cima da fachada principal de um albergue que mantinha as características dos tempos gloriosos em que Don Quixote "se entregava a suas nunca assaz louvadas aventuras" (id., ibid.), uma inscrição dizendo que Miguel de Cervantes Saavedra "mencionó este lugar y barrio en la mejor novela del mundo" e que "varios cordobeses con amor de paysanos y con veneración d'espagnoles dedican este humilde recuerdo al insuperable escritor" (id., ibid.).

Ao contemplar a praça, que tinha "um jeito de sala de jantar", o viajante decide-se por uma refeição numa taberna cujo dono lhe oferece alguns tipos de comida. Ele pode escolher "entre queijo e boquerón, uns peixinhos miúdos, avinagrados, trazidos depressa e comidos sem pão, lentamente, com um jarro de vinho" (LINS, 1980, p.131). Nessa situação, mantém um diálogo com Don Quixote, que lhe "aparece" quando ele se encontrava sentado numa das mesas.

Foi num desses silêncios que o solitário visitante, no momento em que levava à boca, mais uma vez, o copo de vinho, viu à sua frente, de pé, olhando-o com ternura, um homem magro, de uns cinqüenta anos, ou pouco mais. Logo o reconheceu, admirando-se de que não fosse tão alto quanto o 
faziam crer as numerosas gravuras de Doré ${ }^{21}$. Não estava vestido à moda da cavalaria. Trazia uma camisa branca, de mangas folgadas, calças de um tecido que devia ser o vellori de que fala Cervantes e sapatos rasos, bastante cômodos. Mas cobria a cabeça com uma azinhavrada escudela de barbeiro.

A um gesto do viajante, ele sentou-se, estirou as pernas e continuou em silêncio, de perfil. Recusou o vinho; e o boquerón. Por fim, olhando de frente:

- O senhor escreve novelas?

- Sim.

- De cavalaria?

- Não.

Era ligeiramente fanhoso. Pormenor, ao que parece, cuidadosamente omitido por Cervantes.

- Não escrevem mais novelas de cavalaria?

- Não. Há muito tempo.

- Por quê?

- Não há mais cavaleiros.

- Em canto nenhum do mundo?

O outro hesitou, antes de desiludi-lo:

- Não.

- Também não os havia, no meu tempo. Mas eu fui um.

- É verdade.

Dom Quixote passou algum tempo em silêncio, antes de murmurar, como para si próprio, em sua voz nasalada:

- Então, fui mesmo o último.

Ergueu-se com ímpeto, os olhos brilhando:

- Mas nisto é que está a grandeza. Na raridade. Quando eu andava pelos caminhos da Espanha, oferecendo meu braço a todos os desamparados, senhor, estava só. Procure não esquecer, nisto é que reside a grandeza: em ser nobre quando os outros não o são, em ser corajoso quando todos os outros são prudentes, em ficar de pé quando os outros se curvam, em amar quando todos não fazem mais que desejar.

$[\ldots]$

Sem despedir-se, deu um quarto de volta e seguiu em direção à fonte. Seus passos eram largos, mas ele quase não movia os braços. Mal se afastara, desapareceu (id., ibid., p. 131-2; grifos nossos para os trechos maiores).

Esse diálogo "mantido" com Dom Quixote explicita a posição solitária do escritor, bem como a luta, muitas vezes incompreendida e inglória, daqueles que acreditam em seus objetivos e perseguem um ideal. Posição assumida pelo próprio Osman Lins, como escritor que teve "consciência de um compromisso com a palavra, com a língua materna e também com o povo" (LINS, 1979, p. 51), ao qual ele se achava ligado.

${ }^{21}$ O francês Gustave Doré (1833-83), um importante gravurista, ilustrou os 375 desenhos de Don Quixote, de Miguel de Cervantes Saavedra. Sua criação foi tão marcante, que, hoje, não é possível dissociar, de suas gravuras, os personagens do livro. 


\section{II.3. Intertextualidade e memória em Marinheiro de primeira viagem}

Nos fragmentos destacados no item anterior, pudemos acompanhar um diálogo intenso entre diversas áreas culturais: a filosofia, a pintura, a literatura. O inter-relacionamento discursivo não representa uma novidade, propriamente, pois em diferentes épocas a atividade narrativa foi marcada por essa relação, como salienta Leyla Perrone-Moisés (1978, p. 59).

A partir do final do século XIX, as obras literárias sofrem alterações de estrutura, o que abre possibilidades para que elas assumam vários significados e passem mesmo a solicitar diferentes leituras. Essa abertura da interpretação sinaliza a perda da unidade textual. $\mathrm{O}$ "estilhaçamento temático" desencoraja a leitura monolítica que era praticada no passado. Os escritores adotam a nova proposta de recorrer a textos de outros autores, ou para imitar, ou para parodiar, sem estabelecer "distâncias claras entre o original autêntico e a réplica, sem respeito a qualquer hierarquia" de ordem religiosa, estética ou gramatical (id., ibid., p. 59-60). Não há um télos a ser atingido ou conhecido, e destaca-se a possibilidade de "reelaboração ilimitada da forma e do sentido, em termos de apropriação livre” (id., ibid., p. 60).

Também em Marinheiro de primeira viagem pudemos observar que, em algumas situações, os limites entre as fontes e suas referências são tênues, o que torna a prática intertextual muito variada. Ela abrange desde a aproximação explícita e nomeada com uma determinada origem, por meio de utilização de recursos lexicais, semânticos e fonológicos, até momentos de extrema sutileza em seu emprego.

Com a finalidade de esclarecer a questão da intertextualidade, que será um dos instrumentos de reflexão em nosso estudo, faremos uma breve explanação sobre a origem desse conceito até chegarmos ao trabalho crítico de Tiphaine Samoyault (1968), em L'intertextualité - Mémoire de la littérature (2004). As análises dessa teórica ampliam a compreensão do processo de composição mediatizada pela memória cultural que acontece no livro de Osman Lins, como tivemos a oportunidade de exemplificar em "O diálogo viagemarte".

Foi Mikhail Bakhtin (1895-1975), em suas reflexões no livro Problemas da poética de Dostoievski, quem, no fim da década de 1920, forneceu os alicerces para a compreensão da intertextualidade. Ele partiu da compreensão da "polifonia", ou "dialogismo", dos romances de Dostoievski (1821-81), que, segundo suas análises, seriam constituídos pela presença de várias vozes. Bakhtin afirma que o sentido de um "texto é sempre, sob modalidades várias, um intercâmbio discursivo, uma tessitura polifônica na qual confluem, se entrecruzam, se 
metamorfoseiam, se corroboram ou se contestam outros textos, outras vozes e outras consciências" (AGUIAR, 2006, p. 625), em diferentes graus de participação. Para o filólogo soviético, a "abertura dialógica" vincula-se a um "inacabamento de princípio" e uma mobilidade, cuja atitude filosófica reflete uma recusa à centralização do discurso ou a sua estabilidade. Para o estudioso russo, a palavra é "um meio constantemente ativo, constantemente mutável de comunicação dialógica" (BAKHTIN, 1981, p. 176), é sempre a "palavra povoada".

Essas idéias desenvolvidas por Bakhtin são fundamentais para compreender os caminhos seguidos por Julia Kristeva (1941), que, a partir das reflexões desse autor, passou a empregar a palavra "intertextualidade", "termo destinado a conhecer uma fortuna excepcional na teoria e na crítica literárias contemporâneas [...]” (AGUIAR, 2006, p. 625).

Além da teoria de Bakhtin, ela estabelece "pontos de contacto com a leitura anagramática empreendida por Ferdinand de Saussure (1857-1913) em seus Cahiers d'anagrammes (estudos realizados entre 1906 a 1909), [em que o lingüista] levanta a hipótese de que cada poema seria "a chance desenvolvida de um vocábulo simples" (PERRONEMOISÉS, 1978, p. 62). Ela revê o conceito de texto literário e apresenta a noção "paragramática" de método, "que permitirá recolher no texto os gramas escriturais (que dialogam no interior do próprio texto) e os gramas leiturais (que dialogam com gramas de outros textos) (id., ibid., p. 63). É assim que se estabelece uma rede de conexões entre os textos que geram sentidos, que vão sempre além, em busca de novos sentidos. E, no caminho de Bakhtin, é Kristeva quem enuncia: "Todo texto é absorção e transformação de uma multiplicidade de outros textos" (KRISTEVA, 1974, p. 64).

A intertextualidade (PERRONE-MOISÉS, 1978, p. 63) é “este trabalho constante de cada texto com relação aos outros, esse imenso e incessante diálogo entre obras que constitui a literatura". Ao surgir uma nova obra, ela aparece "como uma nova voz (ou um conjunto de vozes) que fará soar diferentemente as vozes anteriores, arrancando-lhes novas entonações”, modulações muito variadas, como as que ressoam em Marinheiro de primeira viagem, de acordo com o que pudemos acompanhar anteriormente.

Após o desenvolvimento desse conceito introduzido por Kristeva, apoiada nos estudos que Bakhtin realizou sobre o dialogismo, surgiram correntes e estudiosos que ampliaram as teorias do texto. Entre eles, destacam-se Roland Barthes (1915-80), Michael Riffaterre (19242006), Gérard Genette (1930), Tzvetan Todorov (1939), cujo posicionamento em relação ao intertexto, ou outras categorias, como hipertexto, hipotexto, arquitexto etc., tem sido divulgado ao longo das últimas décadas. Mais do que as particularidades com que cada autor 
tratou a questão, ou a taxonomia que cada qual escolheu para defender suas idéias, o conceito de intertextualidade, embora hoje se revele até carregado de certa indeterminação, contribuiu para ampliar a pesquisa da produção textual.

Tiphaine Samoyault, em L'intertextualité - Mémoire de la littérature (2004), defende a idéia de que, devido à sua ampla utilização, o termo acabou por abrigar uma noção ambígua no discurso literário: "souvent on lui préfère aujourd'hui des termes métaphoriques qui signalent d'une manière moins technique la présence d'um texte dans autre texte: tissage, bibliothèque, entrelacs, incorporation ou tout simplement dialogue" (id., ibid., p. 5). Com essas denominações é possível simplificar a compreensão do termo e aumentar seu sentido e sua abrangência no texto literário. A literatura mantém relação com o mundo e com a sua história. "Si chaque texte construit sa propre origine (son originalité), il s'inscrit em même temps dans une généalogie qu'il peut faire plus ou moins apparaître" (id., ibid.). A metáfora que ela utiliza, para demonstrar essa "génération non spontanée" em que os textos estão envolvidos, é a de uma árvore com muitas raízes que se multiplicam sob a terra, cujas ligações são tanto horizontais como verticais.

Samoyault está ancorada na idéia de que é possível pensar a intertextualidade de "manière unifiée, en rassemblant ses traits autour de l'idée de mémoire", pois a questão memorial está presente tanto na referência da literatura em relação a ela mesma, como também em sua ligação com o real. "Les effets de convergence entre une œuvre et l'ensemble de la culture qui la nourrit, la pénètre en profondeur, apparaissent alors dans toutes leurs dimensions" (id., ibid., p. 6).

Quando visto sob essa linha analítica, Marinheiro de primeira viagem, devido à sua ampla diversidade textual, revela uma escrita em cujo interior movimentam-se outros textos, e essa mobilidade é o que caracteriza sua novidade em termos literários. Nessa gama de ocorrências intertextuais, é justamente a originalidade (origem e novidade) com que a tradição é referida que vai gerar "la tension entre la reprise et la nouveauté, entre le retour et l'origine, pour proposer une poétique des textes em mouvement" (id., ibid.).

Essa proposta crítica de Samoyault permite-nos ver o livro de Osman Lins como uma obra em que a memória da literatura aparece de forma original e estrategicamente elaborada, em cujos fragmentos há a movimentação provocada pelos amplos textos que o compõem (vozes da tradição, vozes jornalísticas, vozes cinematográficas, vozes cotidianas). Eles estão vivos nos fragmentos, como exemplificamos anteriormente, e, ao mesmo tempo que 
aparecem, inauguram uma nova linguagem no tradicional gênero da literatura de viagem. Além de fazer sobressair a ampla "biblioteca" pessoal a que o autor recorre.

Pelas razões apresentadas, não achamos pertinente fazer levantamentos, nem classificar as práticas intertextuais. E, além disso, não é essa a nossa proposta, mas sim enfatizar, na dinâmica escritural da obra, o papel da memória como "biblioteca", "tessitura", "entrelaçamento" e confluência de textos. Abordagem essa que se nos afigura adequada para expressar o amplo diálogo cultural que Osman Lins condensa em seus registros de viagem e que marca sua poética.

Uma dos tópicos intertextuais que representam em Marinheiro de primeira viagem a recorrência a uma das fontes originárias da poesia e da arte é o que está relacionado ao poeta lendário Orfeu. Seu nome, no livro, aparece para nós como uma "palavra povoada" de significados e intenções, que iremos destacar em seguida ao nos referirmos ao mito grego.

\title{
II.3.1 Referências nominais ao mito do lendário Orfeu em Marinheiro de primeira viagem
}

O nome de Orfeu e de seu mito podem ser identificados nos fragmentos "Noite", “Eurídice”, “Clássico", "Perguntas”, "Exodus”, “O Anti-Orfeu”, como podemos conferir:

\author{
Fragmento "Noite"22
}

\begin{abstract}
As imensas bandeiras estalavam. Luzes amarelas iluminavam as numerosas pontes, os canais, as casas mais antigas, nas quais não se entrevia um bicho, um ser humano. Passavam botes carregados de excursionistas: banhados pela luz amarela, pareciam mortos, transidos de pavor, atravessando o Estige. A voz do barqueiro infernal ecoava entre as escuras paredes dos canais. De 15 em 15 minutos, soavam os carrilhões da catedral. Isto enervava, aquela advertência contínua sobre o fugir do tempo (LINS, 1980, p. 56; grifos nossos).
\end{abstract}

\section{Fragmento "Eurídice"23}

Era a amiga da infância. Tinha os olhos negros e vivazes. Gostava de mangas. Leu, com ela, sentados os dois no mesmo sofá de vinhático, na sala da bisavó, um romance em quase duzentos folhetins: Sônia ou o Calvário do povo russo. Choravam, os dois, com as desventuras de Sônia, expulsa de casa, sob o inclemente inverno de São Petersburgo.

\footnotetext{
${ }^{22}$ Osman Lins, Marinheiro de primeira viagem, p. 56.

${ }^{23}$ Ibid., p. 66.
} 
Fragmento "Clássico" 24

Por que motivo, nestes últimos dias, lembra seguidamente seus olhos inquietos, o sofá de vinhático, a sala da bisavó e os percalços de Sônia, heroína russa? (LINS, 1980, p. 66).

Incansável, pergunto ainda a um fabricante de cestos onde é o túmulo do poeta entre todos, aquele que em passados modulou cantos agrestes ao som de uma delgada charamela. $\mathrm{O}$ bondoso cesteiro, chamando um menino, fez com que este me acompanhasse. $\mathrm{O}$ menino pediu-me cigarros, não os tinha, dei-lhe uma propina. Ele agradeceu e deixa-me sozinho. Eis então que se aproxima um velho jardineiro e pergunta se quero ver a tumba de Virgílio.

- Sim.

- $\quad$ Pois não é aqui, senhor, é mais em cima.

Subi. No estreito caminho, oscilavam flores não desabrochadas. Não havia marcas de passos, a impressão que se tinha era a de um caminho pouco freqüentado. Passei pelo túmulo de Leopardi e então me vi diante da morada de Virgílio. Uma escavação à direita, lembrava a entrada do Hades (id., ibid., p. 94; grifo nosso).

\section{Fragmento "Perguntas",25}

De onde vem esta convicção de que Eurídice encontra-se na Espanha, no Colégio Mayor de Guadalupe? Contaram-lhe isto? Acaso sonhou? Foi notícia vinda em algum cartão-postal, lido distraidamente, jogado numa gaveta ou guardado entre as páginas de um livro? Que símbolo se cristaliza em torno desta amiga de nome legendário? Não é certo que há mais de vinte e cinco anos a perdeu de vista e que Eurídice, assim como o seu tempo, de que foi o signo, está morta? (id., ibid., p. 107; grifos nossos).

\section{Fragmento "Exodus"26}

[...] Mas não é apenas a fuga dos amigos, das amigas, que provoca, em mim, a sensação de estar sobrando, de que terminou em Paris meu tempo áureo, de que devo ir-me quanto antes. A temperatura sobe e a cidade entra em férias. A maioria dos teatros já fechou, a lavanderia de que fui cliente pôs um cartaz na vitrina, anunciando a fermeture annuelle, fecham-se cafés, cinemas, restaurantes, bares. A cidade torna-se um deserto.

Nesse deserto, alguém me telefona. Não estava no Hotel, quando o telefone chamou. E a pessoa não deixou seu número. Disse-lhe a gerente que Monsieur estava sur le point d'aller en Espagne. Terá sido Eurídice? Não voltou a me telefonar (LINS, 1980, p. 110-1; grifos nossos).

\footnotetext{
${ }^{24}$ Ibid., p. 94.

${ }^{25}$ Ibid., p. 107.

${ }^{26}$ Ibid., p. 110-1.
} 


\section{Fragmento "O Anti-Orfeu"27}

No aeroporto, ressoará a pausada e neutra advertência dos alto-falantes. Haverá um movimento coletivo de gente que se ergue, despede-se, converge. Às suas costas, soará outro chamado; pronunciarão seu nome, voz de mulher. Não a reconhecerá. Ela estará sorrindo, um riso de quem tem bom coração.

- Eurídice?

Responderá:

- Não. Você bem sabe que Eurídice morreu há muito tempo. A viagem acabou. A infância acabou. Eurídice está morta (id., ibid., p. 143; grifos nossos).

\section{II.4. O mito grego de Orfeu}

Em vários fragmentos identificamos referências nominais ao mito de Orfeu e de sua amada Eurídice. Dada sua relevância para a leitura de Marinheiro de primeira viagem, julgamos pertinente resgatar a lenda do antigo poeta da Trácia, filho de Calíope, uma das nove Musas, e do rei Eagro.

Orfeu é um personagem mítico cujo nome está relacionado à poesia e à música, dois recursos que, aliados à sua divina voz, encantavam a todos os que o ouviam. Segundo a lenda, ele provocava uma sedução tão avassaladora, que a roda de Exíon deixou de girar, o bloco de pedra de Sísifo parou de rolar montanha abaixo, e Tântalo, que fora condenado por Zeus a sentir fome e sede, chegou até a esquecê-las, tal o fascínio de Orfeu.

O poeta casou-se com a ninfa Eurídice, a quem amava profundamente e a quem considerava parte de sua alma: ela era a metade de sua alma, isto é, a pessoa amada. No dia do casamento, o apicultor Aristeu, atraído pela beleza da noiva, perseguiu-a, e, na fuga, Eurídice pisou numa serpente, que a picou, vindo a causar-lhe a morte. Orfeu fica inconformado, e decide descer ao mundo dos mortos para buscá-la.

Os deuses do Hades, Plutão e Perséfone, ficaram comovidos com o grande amor de Orfeu por Eurídice e, sabedores do quanto ele era venerado por seus dotes poéticos, decidiram permitir que ele fosse ao reino subterrâneo para que de lá resgatasse a esposa. Uma condição, todavia, foi imposta: ele deveria ir à frente, seguido por ela, mas, enquanto estivessem no mundo dos mortos, ele não poderia olhar para trás. Ele aceita inicialmente as regras, mas, quando estavam quase para sair das trevas infernais, Orfeu foi tocado pela dúvida de ter sido enganado pelos deuses. Movido pelo “invencível póthos, pelo desejo grande da presença de

\footnotetext{
${ }^{27}$ Ibid., p. 143.
} 
uma ausência, o cantor olhou para trás, transgredindo a ordem dos soberanos das trevas. Ao voltar-se, viu Eurídice, que se esvaiu para sempre numa sombra” (BRANDÃO, 2001, p. 142). Novamente ele tentou regressar, mas o barqueiro Caronte, que tinha por incumbência transportar as almas em sua barca pelos rios do Hades, não deu a autorização para o retorno ${ }^{28}$.

Em conseqüência da desilusão, Orfeu afastou-se de todas as mulheres. Por causa disso, as Mênades, inconformadas com a fidelidade que o poeta dedicava à esposa morta, mataramno e fizeram-no em pedaços, atirando-os ao Ebro. Segundo conta a lenda, sua cabeça rolava rio abaixo, sempre repetindo: "Eurídice, Eurídice..."29

\footnotetext{
${ }^{28}$ Nas Geórgicas (L,IL), de PubliusVirgilius Maro (70 a.C.-19 a.C.) (trad. de António Feliciano de Castilho e Manuel Odorico Mendes), podemos acompanhar uma das passagens mais belas desse momento:
}

"Já vinha desandando o lôbrego caminho, redivivo ao prazer, e salvo dos azares. Restituída a seus ais, volvia aos puros ares Trás ele, e não olhada, Eurídice. Tal era A cláusula que ao dom Prosérpina impusera.

“Alucina-se o amante (insânia perdoável, se couberam perdões no abismo inexorável!) pára, já quase à luz... esquece... oh! Luto sua Eurídice encara, e esvai-se à lida o fruto!... Do Averno o cru tirano o pacto há rescindido, E três vezes sai do Orco um lúgubre estampido, Co'a voz dela per meio:

"Orfeu, que amor foi este? Mísera! A mim, e a ti, co’o teu furor perdeste! O fado me revoca! Ai! Sinto os olhos meus Outra vez a nadar no sono eterno... Adeus!... Força estranha me empuxa! A negridão me cerca! Tendo-te embalde as mãos! É força que te perca!” -

"Disse, e desapareceu, qual fumo na atmosfera; sem nunca mais o ver, a ele, que inda espera co'as frenéticas mãos nas sombras apanhá-la, mil coisas quer dizer-lhe, e não atina fala!

“Do Orço o velho Arrais nunca dess'hora avante consentiu mais regresso à malograda amante.

"Duas vezes viúvo, onde é que há-de ir-se agora, que há-de fazer Orfeu? Pranteia, clama, implora, e todo o inferno é surdo, e nenhum deus o atende! "Gelada ao longe a esposa a veia estígia fende.

${ }^{29}$ Nas Geórgicas (L,IL), de PubliusVirgilius Maro. O relato dos infortúnios de Orfeu são contados pelo poeta, como segue:

Orfeu nem se comove a tentações de amores,

Nem se dá d'himeneus. Vai, só com suas dores,

Retrilhando o nevão das hiperbóreas terras,

E do Tanais algente, e das rifeias serras,

A deplorar sem termo Eurídice roubada, 
Diante dessa trágica situação, os deuses interferem mandando uma grande peste, que só seria extinta quando a cabeça de Orfeu fosse resgatada. Finalmente um pescador a encontra no rio Meles, na Jônia, e, em seguida, foi erguido um templo em homenagem ao poeta. A esse local o acesso das mulheres era proibido. Dessa forma se encerra o ciclo de desgraças enviadas do Olimpo.

Como destaca J. Brandão (2001, p. 144), Orfeu desceu ao Hades e poderia ter trazido sua Eurídice de volta, se não tivesse transgredido as ordens. Esse foi seu grande erro, ter-se apegado ao passado, à matéria "simbolizada por Eurídice", e olhado para trás. Ao transgredir o tabu das direções, ele cometeu uma falta irreparável, pois nas culturas antigas a direção do olhar tinha um significado e um simbolismo muito importante: “Olhar para a frente é desvendar o futuro", "para a direita é descobrir o bem”, "para a esquerda é o encontro do mal", "para trás é o regresso ao passado, às hamartíai, às faltas, aos erros, é a renúncia ao espírito e à verdade" (BRANDÃO, 2001, p. 145).

Pelo fato de Orfeu ter feito o que nenhum outro fez, olhar o passado, o invisível, por causa dessa ousadia, ele perdeu Eurídice. O citaredo não pode regressar, nem tocar sua lira, nem cantar. Como comenta Brandão (id., ibid., p. 147), o poeta perdeu-se "como indivíduo, como músico e como cantor". Quebrou-se a harmonia. "Em grego ápuovía (harmonía) significa precisamente 'junção das partes'. Orfeu des-completou-se, des-individuou-se. A segunda parte do sýmbolon se fora. O encaixe, a harmonia, agora somente será possível se houver um 'retorno perfeito"'.

E do cruel Plutão a dádiva frustrada.

“Tão exemptos desdéns, tão longa rebeldia trocaram afinal o afecto em sanha ímpia nos ígneos corações das cícones amantes.

Entre o rito nocturno, ao moço; investem-no mil braços;

Cai; pelo campo todo atiram-no pedaços.

"Que termo! E a que viver! Lhe não impôs seu astro!

A cabeça arrancada ao colo de alabastro

Ia-se a volutear no Ebro, na corrente

Do Eagro, de seu pai, mas inda a voz cadente

Côa língua regelada - "Eurídice" dizia;

- "Eurídice infeliz" - chamava na agonia;

e em todo o rio ao longo as margens em tom brando

- "Eurídice infeliz" - ficavam murmurando. 


\section{II.4.1 A recepção e o efeito do mito de Orfeu em Marinheiro de primeira viagem}

Falar do mito de Orfeu em Marinheiro de primeira viagem é defender a participação do leitor na recepção da obra de arte escrita e o efeito dessa leitura. Esse é o ponto de vista a partir do qual se desenvolveu a estética da recepção, que abrange a Teoria da Recepção, de Hans Robert Jauss (1921-77), a Teoria do Efeito, de Wolfgang Iser (1926-2007) e a Teoria da Ação, de Hans Ulrich Gumbrecht (1948). Por ora, nos ateremos apenas às idéias dos dois primeiros teóricos.

A estética da recepção, na década de 1960, surge na Alemanha para quebrar paradigmas dos estudos literários. Na mesma época em que Hans-Georg Gadamer, exprofessor de Jauss na Universidade de Heidelberg, apresenta em Verdade e método (1960) um novo encaminhamento para a hermenêutica, ao lhe atribuir o encargo de intérprete da história, seu ex-discípulo vai resgatar alguns conceitos da fenomenologia, as noções de pré-juízo e tradição, e desenvolver sua idéia de "consciência histórica dos efeitos". Com esse trabalho, Jauss oferece um novo rumo para as investigações sobre a interpretação, tema que despertara o interesse de pensadores de várias épocas como F. D. Ernst Schleiermacher (1768-1834), Wilhelm Dilthey (1833-1911) e Martin Heidegger (1889-1976), cada qual dando sua própria contribuição ao problema da interpretação.

Ao defender a proposta de resgatar a história da literatura numa vertente outra que a do estruturalismo e do marxismo, encontra apoio nas idéias de seu antigo mestre Gadamer. E, além da história, como esteio para o conhecimento do texto, ele destaca a importância do receptor da obra nesse processo. Ele propõe uma concepção de estética aberta, avessa aos dogmatismos, ao fechamento das fórmulas rígidas, e desloca o interesse teórico, antes centrado em questões de produção e representação, para tópicos referentes à leitura e ao leitor. A leitura, como comenta Teresa Cruz no prefácio de $A$ literatura como provocação $(2003, \mathrm{p}$. 9), é "a actividade que efetivamente abre os mundos do texto, transformando-o em experiência" e faz entrar, "na compreensão do fenômeno literário, a personagem esquecida de quase toda a Teoria literária - o leitor".

$\mathrm{Na}$ perspectiva da estética da recepção, além da convergência no texto entre leitor e escritor, não existe oposição entre o aspecto histórico e o estético, é a cadeia de recepções "que decidirá sobre a importância histórica de uma obra e sobre seu destaque estético" (JAUSS, 2003, p. 58), no presente. O diálogo com as obras do passado dependerá da capacidade de ela manter-se e de "tomar parte activa na totalização contínua do passado, operada pela experiência estética" (id., ibid.). 
A compreensão de um fato literário está continuamente mudando e só continuará "a exercer seu efeito, enquanto for ainda, ou de novo, recebido pela posteridade - enquanto encontrar leitores que se apropriem de novo da obra, ou autores que a pretendam imitar, ultrapassar ou recusar" (id., ibid., p. 64).

Para a estética da recepção, a leitura resulta da interação entre o leitor e o texto, é um diálogo em que deve haver coerência a partir daquilo que é dito ou sugerido, e nessa relação o receptor exerce um papel de destaque, na medida em que tem a função de construir significados.

Achamos importante ressaltar a importância dessa orientação teórica em nossa investigação, pois, quando tratamos da forma circular em que se estrutura Marinheiro de primeira viagem e abordamos as questões intertextuais referentes ao mito de Orfeu, já demos alguns passos no sentido de uma ação interpretativa e de atribuição de significado ao livro, embora esses elementos não se apresentem explicitamente nos resultados alcançados até o momento.

Como destaca Iser (1996, p. 57), "os textos contêm elementos de indefinição", e esta “indeterminação não é um defeito, mas constitui condição elementar de comunicação do texto que possibilita que o leitor participe na produção da intenção textual". Iser destaca "um novo operador: o de 'lugar vazio'. [...] O vazio exige do leitor uma participação ativa".

Essa é uma concepção que acaba por se chocar com a visão tradicional de obra literária em que "a obra não só pedia uma interpretação - que, no mais das vezes, não passava de uma glosa -, como supunha que haveria uma interpretação correta" (LIMA, 2002, p. 26). Iser nega a existência de uma única interpretação correta ou do papel didático da obra literária e ressalta que lhe é própria uma característica pendular (id., ibid., p. 27). "É por essa pendularidade que a obra literária é passível de manter a abertura de sua indeterminação" (id., ibid.). Com isso, ele deixa claro que sua concepção afasta-se do resultado "positivo", da interpretação "correta".

Segundo Costa Lima:

Não se trata de indagar se a interpretação é ou não necessária. Pelo próprio encaminhamento já feito, compreende-se que esta não é uma questão de opção. Sempre se interpreta. A verdadeira questão consiste em saber qual sua relevância (id., ibid., p. 25).

Conforme expõe esse teórico, o operador "lugar vazio" pode aclarar a questão, e remeter à idéia de indeterminação, que, embora não seja exclusividade do texto literário, nele 
sobressai. Ele faz questão de declarar que trata-se de um trabalho de "suplementar o(s) vazio(s)", e não de “o(s) complementar" (id., ibid., p. 26).

No "jogo" do texto em Marinheiro de primeira viagem identificamos um tipo de suplementação que o leitor pode acrescentar à leitura desse livro, pela reunião dos vários ecos do mito de Orfeu que aparecem ao longo dos fragmentos. O posicionamento teórico de Iser permitiu-nos essa liberdade no processo interpretativo e estimulou-nos a buscar os suplementos que ofereciam sentido para essa leitura e que eram sugeridos pela movimentação pendular que caracteriza a obra. Esse livro de Osman Lins é particularmente marcado por uma dinâmica interna e uma abertura interpretativa que instiga o leitor a captar seu "modo de criação de mundo".

Apoiados nessa linha teórica, julgamos pertinente destacar o papel desempenhado pelo mito de Orfeu no texto osmaniano, tanto pela forma narrativa em que estão escritas essas lembranças, que remetem aos personagens gregos, como pelas reflexões sobre o sentido da viagem expressas pelo autor.

A poética da recepção ou poética da leitura integra o leitor à obra e abre espaço para que ele manifeste os significados oriundos dessa relação. Com o mito de Orfeu, podemos observar esse fenômeno. Ao longo do tempo, sua história é retomada de diversas formas e em diversos contextos. A carga estética presente em Orfeu renasce a cada nova citação dele ou alusão a ele feita por um novo artista.

Se partirmos de um ponto, a Grécia antiga, local em que o mito nasce, a imagem de Orfeu já está associada à do viajante que perambula pelo continente africano, vai ao Egito e visita vários povos, com o objetivo de instruir-se. Seu nome está ligado ao conhecimento e à poesia, bem como à música. $\mathrm{O}$ mesmo se dá com o viajante em Marinheiro de primeira viagem, quando decide fazer um longo estágio cultural pela Europa, onde terá ocasião de enriquecer-se em várias áreas do conhecimento.

A história de Orfeu é rica em detalhes sobre a alma humana, recomeça com Virgílio (70-19 a.C.) e, desde então, está sempre renascendo das formas mais inesperadas. Se realizarmos uma estimativa de quantas referências ao mito de Orfeu foram feitas até os dias de hoje, veremos que elas são incontáveis. Em todos os tempos, escritores, poetas, pintores recorreram a ele, para traduzir suas mensagens. O horizonte de expectativas que seu nome evoca parece não se esgotar.

No tempo em que Osman Lins escreveu Marinheiro de primeira viagem, também o poeta lendário da Antiguidade recebeu inúmeros destaques, e, entre eles, podemos mencionar, 
por exemplo, o que lhe concedeu Jean Cocteau. O poeta-cineasta o fez renascer nos filmes, grandes sucessos de bilheteria, Orfeu (1951) e Testamento de Orfeu (1959), em que focaliza o mito contextualizado no mundo moderno. Assistir a esses filmes, ainda hoje, causa impacto, tal o vanguardismo do cineasta. Das inovações de Cocteau, tanto no cinema quanto no teatro, Osman Lins revela que delas tinha consciência, e essa lembrança não deixa de refletir-se em suas próprias criações. Podemos conferir a existência dessa ligação no fragmento intitulado “Edwige, Balmain, Cocteau" (LINS, 1980, p. 17-8), em que o narrador relata um momento do viajante no Teatro Sarah Bernhardt, em Paris, no qual tece alguns comentários sobre a maneira peculiar de construção das cenas e diálogos criados pelo cineasta para a representação de Edwige Feuillère ${ }^{30}$.

Outra referência significativa, ao poeta mítico, aqui no Brasil, no tempo de Osman Lins, é o filme Orfeu Negro (1959), do cineasta Marcel Camus, baseado na peça Orfeu da Conceição (1954), do poeta brasileiro Vinicius de Moraes (1913-1980). Premiado com a Palma de Ouro no Festival de Cannes, em 1959, e o Oscar de Melhor Filme Estrangeiro, em 1960, foi ainda indicado para receber o Globo de Ouro, por essa categoria.

O tema de Orfeu também está presente na produção do alagoano Jorge de Lima (18931953), com seu poema Invenção de Orfeu (1952), que destaca os conflitos material e espiritual do homem numa obra épica em que o tempo e o espaço estão ausentes.

Há que se acrescentar a todas essas menções as obras do pintor Gustave Moreau (1826-98), um dos mais representativos impulsionadores da arte simbolista que marcou o século XIX. Várias das pinturas de Moreau ligam-se ao interesse de nosso estudo: "Le poète voyageur" (c.1890), “Orphée” (1865), “Orphée sur la tombe d’Eurydice” (1897), "Poète mort porté par um centaure" (c.1890). E algumas delas estiveram expostas na exposição Gustave Moreau, no Louvre em 1961, e também no Musée National Gustave Moureau, instalado na antiga casa do artista, em Paris. E podemos afirmar, sem medo de errar, que Osman Lins tomou conhecimento da existência dessas obras, quando lá esteve, elas faziam e ainda fazem parte do roteiro cultural da França.

Ao lembrar essas obras, que estiveram em evidência nos anos 1950 e 1960, não podemos deixar de acrescentar a esse elenco de menções e utilizações do mito de Orfeu a famosa revista literária portuguesa Orpheu, publicada em 1914-5, que marcou a revelação do poeta Fernando Pessoa e registrou a necessidade de pensar-se uma nova estética literária. Embora haja distância cronológica considerável, entre a data de lançamento da revista e a

\footnotetext{
${ }^{30}$ Edwige Feuillère foi uma famosa atriz dos anos 1950 e 1960, na França.
} 
produção literária de Osman Lins, a existência de Orpheu na tradição modernista lusobrasileira certamente pesou na formação de um intelectual atento como ele.

Quando identificamos o mito de Orfeu em Marinheiro de primeira viagem, nossa intenção não é ressaltar o que há de subjetivismo em sua leitura, mas sim mostrar que esse é um tema vigoroso na experiência literária do livro. Além de a referência ao poeta-cantor lendário vir impregnada da carga cultural e memorial que seu nome carrega, a relação com o mito fortalece a narrativa. Isso pode ser observado tanto pela forma circular de sua estrutura quanto pelas evidências explícitas das ocorrências nominais que aparecem ao longo dos fragmentos, como destacamos anteriormente.

Por essa razão, julgamos pertinente tecer alguns comentários sobre o significado do mito, visto que essa abordagem suplementar envolve a tríade "autor-texto-leitor" numa íntima relação performativa. E, para esclarecer como esse "algo novo é modelado", no caso de Marinheiro de primeira viagem, faremos algumas apreciações sobre o mito, sobre o papel da memória e da mensagem que emana da forma em que o livro está escrito.

\section{II.5. O papel da memória em Marinheiro de primeira viagem}

"Mito é a palavra, a imagem, o gesto, que circunscreve o acontecimento no coração do homem" (BRANDÃO, 2000, p. 36), muito antes de ser "inteligido". Muito mais do que captar o que ele aparenta, é preciso "buscar-lhe os significados", o seu "sentido profundo" (id., ibid., p. 37), em que revive uma determinada ação. Reviver o mito é a palavra de ordem dada no rito. $\mathrm{Na}$ repetição ritual há uma volta às fontes originais para se "readquirir as forças que jorram nessas mesmas origens" (id., ibid., p. 39), tendo como "finalidade [...] recuperar o tempo forte, o tempo primordial" (id., ibid.), daí sua forma circular.

O mito liga-se à idéia de reiteração do tempo, isto é, à possibilidade de dizer-se alguma coisa ou de se poder fazer algo novamente, e, é no ritual, na ação, que o momento sagrado pode ser recuperado. Nas culturas antigas, a regularidade cósmica era observada na repetição das estações, no ciclo de um novo ano que ao nascer está vinculado ao seu término e configura a possibilidade de sua (re)atualização e renovação. Como afirma Mircea Eliade (2004, p. 72): “O fato essencial não é o Fim, mas a certeza de um novo começo”. A palavra "mito" significa narrativa de um conhecimento, de uma visão de mundo, nunca uma mentira ou falsidade, e sua função "é a de revelar modelos e fornecer uma significação ao mundo e à 
existência humana. Graças ao mito, o mundo pode ser discernido como um Cosmos perfeitamente articulado, inteligível e significativo" (ALMEIDA, 1988, p. 63).

Nossa concepção atual de tempo é profana e linear, o passado, o presente e o futuro que a compõem estão desvinculados do sagrado. São momentos irreversíveis sobre si mesmos. Nós podemos comemorar um determinado evento, e comemoramos, mas não podemos fazê-lo voltar. Só "o tempo mítico, ritualizado, é circular, voltando sempre sobre si mesmo" (BRANDÃO, 2000, p. 40), é ele que promove e libera "o homem do peso morto, dando-lhe a segurança de que ele é capaz de abolir o passado, de recomeçar sua vida e recriar seu mundo" (id., ibid.).

Falar de mito é falar de tempo e memória, e vale destacar que em Marinheiro de primeira viagem esta tem uma função diferente da encontrada no livro Em busca do tempo perdido (1913-27), de Marcel Proust (1871-1922), no qual a memória involuntária, que está adormecida em nós, pode ser despertada a qualquer momento por um cheiro, um toque ou qualquer sensação, abrindo um espaço poético em que as recordações que estavam latentes podem aflorar.

Como revela Proust em No caminho de Swann, primeiro volume de Em busca do tempo perdido, falando sobre essa possibilidade:

É trabalho baldado procurar evocá-lo, todos os esforços de nossa inteligência serão inúteis. Está escondido, fora de seu domínio e de seu alcance, em algum objeto material (na sensação que esse objeto material nos daria), que estamos longe de suspeitar. Tal objeto depende apenas do acaso que o reencontremos antes de morrer, ou que o não encontremos jamais (PROUST, 2004, p. 51).

Em Proust, podemos acompanhar esse despertar, do ponto de vista do narrador: ao saborear um pequeno biscoito (madeleine), subitamente seu passado aflora, e toda a sua história pessoal vem à sua consciência: Diz ele: "Minha mãe, vendo-me com frio, propôs que tomasse, contra meus hábitos, um pouco de chá" (id., ibid.). E, ao beber o chá, deixou que amolecesse na boca "um pedaço de madeleine". No instante desse primeiro gole, ele sentiu que algo diferente e extraordinário lhe acontecia e, a partir dessa sensação, foi buscar a lembrança em seu espírito, e esta lhe apareceu: “Aquele gosto era o do pedacinho de madeleine que minha tia Léonie me dava aos domingos pela manhã em Combray [...], depois de mergulhá-lo em sua infusão de chá ou de tília" (PROUST, 2004, p. 52). Mas o que o narrador descobre é que não só as lembranças pessoais lhe surgem, mas toda a cidade de 
Combray de então, onde passou grande parte de sua infância: "[...] e toda Combray e suas redondezas, tudo isso que toma forma e solidez, saiu, cidade e jardins, de minha xícara de chá" (id., ibid., p. 53).

Em Marinheiro de primeira viagem, as lembranças processam-se de maneira diferente. Ao clamar, no primeiro fragmento, "que se evoquem hoje, o desembarque em Bordéus, num sábado de Carnaval, as primeiras horas neste continente" (LINS, 1980, p. 7), o narrador lança mão da memória voluntária para começar a contar os primeiros momentos de sua chegada na França, após um longo período a bordo do navio que partiu de Recife.

"Que se evoquem" é uma expressão poética, mas ao mesmo tempo é uma tomada de atitude. A "evocação" à memória dá um tom épico à narrativa inicial e sugere a presentificação do passado. E, como afirma Tynianov (citado em BERNARDINI, 2000, p. 33), certas palavras têm a propriedade de realce na dinâmica poética, caso dessa "evocação" inicial em Marinheiro de primeira viagem, que tem o que ele chama de indício fundamental de significado. Ao evocar suas lembranças, o narrador também não fica à mercê das Musas (e da mãe das nove Musas, Mnemosýne, a memória), como faziam os poetas das epopéias antigas, que delas recebiam a revelação do passado, por lhes ser dado o poder de intercâmbio com o divino. O narrador não se entrega às Musas, nem depende de uma sensação que lhe desperte seu passado, mas, de início, a expressão sugere que vai ser relatado algo extraordinário que lhe aconteceu: o apelo à memória unifica os fragmentos e os integra à história vivida pelo viajante. Dessa maneira, o leitor, ao abrir o livro Marinheiro de primeira viagem, não sabe que vai encontrar fragmentos isolados, pois, ao ler a primeira página do livro, é informado apenas de que recordações serão narradas.

Mircea Eliade (2004, p. 110) ressalta que os gregos valorizavam dois tipos de memória: uma ligada à cosmogonia, teogonia e genealogia, e outra ligada aos acontecimentos "históricos e pessoais". O "esquecimento" (Letes) "opõe-se com igual eficácia às duas espécies de memória", mas "é impotente em face de alguns privilegiados", como é o caso dos inspirados pelas Musas, que a resgataram dos "eventos primordiais", e aqueles, como Pitágoras e Empédocles, que alcançaram a recordação “de suas existências anteriores”. São essas “duas categorias de privilegiados [que] superaram o 'Esquecimento' e, conseqüentemente, também a morte, de certa maneira". Os que alcançam a recordação de "suas existências anteriores" recuperam a "sua própria história" vivida nas várias encarnações, daí o esforço de unificar os eventos isolados para "integrá-los numa única trama, a fim de descobrir o sentido de seu destino". Pois a unificação, por meio da anamnesis, de 
fragmentos de história sem qualquer relação entre si resulta igualmente em 'unir o começo ao fim"” (ELIADE, 2004, p. 111).

Embora Marinheiro de primeira viagem não trate de questões religiosas, como as implicadas nas crenças órficas, que tinham no cantor-poeta Orfeu seu mestre e patrono e defendiam a metempsicose, o vegetarismo, a catarse, esse livro apresenta contatos com a estrutura do mito e revela tendência mitologizante de seus registros.

Em seguida, apontaremos os fragmentos de Marinheiro de primeira viagem que se referem ao mito de Orfeu. Em "Noite" (LINS, 1980, p. 56), no qual há destaque para o Estige, um dos rios que era preciso atravessar para chegar ao Hades, bem como é feita menção ao "barqueiro infernal", Caronte, que transportava as almas para o mundo subterrâneo. Em outro fragmento, intitulado "Clássico" (id., ibid., p. 66), o nome do poeta Virgílio (70 a.C.-19 a.C.) aparece associado à entrada do Hades, um fato significativo, pois foi pela poesia do poeta mantuano que detalhes da história de Eurídice chegaram até nós.

A amada do cantor-poeta mítico também aparece nos fragmentos "Eurídice" (p. 66), "Perguntas" (id., ibid., p. 107), "Exodus" (id., ibid., p. 110-1) e "O Anti-Orfeu” (id., ibid., p. 143), que expressam chamamento e tentativa de reflexão. Talvez, mais do que isso, essa figura represente um "símbolo", e símbolo quer dizer "encontro, conjunção, é o elemento que, no mundo mítico, eleva os indivíduos ao mais alto grau de realidade” (FABRI, 1988, p. 33). A menção surge nesta passagem: "Que símbolo se cristaliza em torno desta amiga de nome legendário? Não é certo que há mais de vinte e cinco anos a perdeu de vista e que Eurídice, assim como o seu tempo, de que foi o signo, está morta?” (LINS, 1980, p. 107). Ou neste outro momento: "Disse-lhe a gerente que Monsieur estava sur le point d'aller en Espagne. Terá sido Eurídice?” (id., ibid., p. 111). Ou, ainda, como se observa nesse outro trecho: "Eurídice? Responderá: - Não. Você bem sabe que Eurídice morreu há muito tempo. A viagem acabou. A infầncia acabou. Eurídice está morta” (id., ibid., p. 143).

Assim como faz o mito, que, ao unir os fragmentos aparentemente isolados, monta uma história, Marinheiro de primeira viagem revela-se um artesanato literário que convida o leitor a uma experiência estética e interpretativa inovadora. Os fragmentos estão organizados como num trabalho de bricolage, técnica artesanal que consiste em se produzir um novo objeto formando-o pela composição de vários materiais, mas sem que cada elemento formador perca suas características originárias. Esse é, por excelência, o modo de composição do mito, que constrói sua história a partir de pedaços de narrativas. Com essa técnica artesanal, Osman Lins revela as lembranças que foram vividas primeiramente em seu coração e reconstrói os momentos sentidos e interpretados por ele. 


\section{II.6. A partida e a despedida do Anti-Orfeu}

No último fragmento, intitulado "O Anti-Orfeu" (LINS, 1980, p. 142-4), o narrador descreve os instantes finais do viajante na Europa e resgata as lembranças de quando lá chegou, entremeando momentos da entrada no continente europeu com os da partida: "Logo ficará para trás o continente, com sua carga de gente e de passado. [...] Recordará, entre outras lembranças, o desembarque em Bordéus, o cinza, a solidão e o frio daquela primeira manhã européia, [...]" (id., ibid., p. 142). E acrescenta os derradeiros momentos do viajante, na casa de amigos portugueses, quando, após ser levado ao aeroporto, eles se despedem: "O abraço de adeus" (id., ibid., p. 143). Num ritmo próprio, a memória continua a resgatar momentos vividos no clube de dança, seis meses antes: "Moças dançavam com moças, rapazes levavam o contra (porque desconhecidos, ou porque antipáticos): as jovens damas mentiam, diziam estar cansadas, em seguida aceitavam outro convite" (id., ibid., p. 143).

O viajante já se encontra no aeroporto, e, novamente, as lembranças são interrompidas pela voz que soa dos altos-falantes, mas o que lhe chama a atenção é uma outra voz que se faz ouvir "às suas costas" (id., ibid.), como podemos apreciar a seguir:

No aeroporto, ressoará a pausada e neutra advertência dos alto-falantes. Haverá um movimento coletivo de gente que se ergue, despede-se, converge. Às suas costas, soará outro chamado, pronunciarão seu nome, voz de mulher. Não a reconhecerá. Ela estará sorrindo, um riso de quem tem bom coração.

- Eurídice?

Responderá:

- Não. Você bem sabe que Eurídice morreu há muito tempo. A viagem acabou. A infância acabou. Eurídice está morta. Eu sou o tempo futuro, a vida por viver.

Tudo isso, entrecortado pelas lembranças da visita à cidade de Tours, cuja descrição já fora narrada em "Tours" (id., ibid., p. 8) e é agora repetida na narração desses momentos finais:

Entre os ramos nus das árvores, em Tours, esvoaçavam pássaros. Batia, a espaços, o portão do jardim. Os bastões de bronze da lojinha, de várias dimensões, chocavam-se entre si. As pessoas tornavam-se crianças, e desejavam entrar, sair, durante horas, para abrir e fechar aquela porta, com seus bastões eternamente prontos a saudar, com a música idêntica a si mesma e todavia variável ao infinito, todos que entram, todos que se vão.

O esvoaçar dos pássaros, as batidas do portão de ferro e o som que saudava os que entravam e os que saíam evocam uma situação onírica, de "passagem”, além de remeter ao 
poético os momentos finais do viajante, ao deixar "aquela pausa e seu encantamento, para todo o sempre no passado"31.

O diálogo do viajante, com alguém às suas costas continua:

- Se você é a vida por viver, porque está aqui, de onde parto?

- Não estou aqui. Apenas, me anuncio. Espero-o do outro lado. Quero que prepare o coração.

- Vou reencontra-la?

- Vai encontrar-me.

- Como?

- Será simples, e também inevitável. Assim como encontrar o dia de amanhã. (LINS, 1980, p. 143).

Ao penetrar no jogo poético-existencial que o mito desempenha na construção do sentido dessa narrativa osmaniana, podemos entender que essa conversa tenha se dado com uma psykhé ( $\psi v \chi \eta ́)$, que, segundo o orfismo, é a parte divina do homem, é a sua inteligência, desempenhando nessa concepção o papel de parte imaterial e imortal do ser.

Esse era um momento muito especial, pois o viajante estava deixando a Europa, o seu Hades - o passado, o mundo dos que já viveram -, e por essa razão ele pode dialogar com eles, num espaço que é o da intimidade do próprio ser. Desse diálogo o que se destaca é o tom

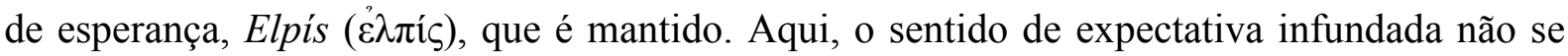
aplica, mas sim o do grego, que significa "a uma só vez, expectação do bom e do mal e que, no espaço da interioridade, tem voz e dialoga com o homem, incitando-o a agir ou a pacientar" (LAFER, 2006, p. 92). Tarefa essa que é essencialmente humana. A expectação faz parte da condição humana, essa oscilação entre uma situação e outra. "Platão (Leis, 644 c-d) diz que as opiniões que concernem ao futuro levam o nome comum de Elpis” (LAFER, 2006, p. 73).

Em seguida, o viajante percebe que ainda estava, porém, carregando muito material desse passado. Ele não poderia, como Orfeu, e tentar trazer de volta o passado e fazê-lo reviver. Ele passa por um rito, que é o da catarse, significando o despojamento:

Sentindo-se, de súbito, atado a uma porção de coisas mortas, tira do bolso um maço de postais e de retratos, oferece a um menino uma vista da Holanda. E também um retrato de mulher, e fotografias de praças em Londres e Florença, canais, pontes, castelos e praias, cerimônias públicas, enche as mãos das crianças de coisas e pessoas a que ainda estava preso, sente-se mais leve, e o milagre é que tudo revivia ao contato daquelas mãos estranhas (LINS, 1980, p. 143-4).

31 Entrevista de Osman Lins a Esdras do Nascimento sobre Marinheiro de primeira viagem, Tribuna da Imprensa, RJ, 26/08/1963, consultada no IEB-USP. Reproduzimos esta matéria no Anexo 2, item 1. 
Ao terminar sua catarse, ele não olha para trás como fez Orfeu, assim não correu o risco de se "des-individuar", como aconteceu ao poeta que foi despedaçado pelas Mênades por seu total apego ao passado, simbolizado por Eurídice. O "viajante" manteve-se íntegro, “de coração confiante", não transgredindo o tabu das direções, como fez Orfeu. Lembrando o comentário de Brandão (2001, p. 145): "Olhar para a frente é desvendar o futuro e possibilitar a revelação".

A "revelação" o viajante a teve, ele dialogou com ela. Numa clara menção ao fato de que a escolha da direção a seguir não é algo que está determinado pelos deuses - ananque -, mas sim é parte da construção da própria vida a que os humanos estão sujeitos.

Em Marinheiro de primeira viagem, o viajante inicia sua experiência em terras estrangeiras como Orfeu, que perambulou pelo mundo em busca de conhecimento. Ele mostrou-se disposto a viver in loco seu passado cultural tão bem guardado e representado pelo Velho Continente. Ao partir, porém, ele revela-se oposto a Orfeu, um Anti-Orfeu. Ele deixa o aeroporto, sem apegar-se ao passado, diferentemente do que havia acontecido ao antigo cantor-poeta, que em sua descida ao Hades perdeu a sua Eurídice (seu passado) e também se perdeu como indivíduo.

Ao mesmo tempo, podemos entender que o viajante enfrentou uma espécie de "morte". Neste caso, uma catábase - uma descida de iniciação nessa sua jornada, como marinheiro de primeira viagem. Mas também realizou o movimento de retorno, a anábase - a subida -, quando deixou o aeroporto:

Apanhou outra vez sua valise e de bolsos vazios avançou. Em que direção, ou no rumo de quem? Ecoavam os megafones, os possantes motores de avião roncavam. Em seguida. Sem olhar para trás, de coração confiante. A assoviar. Desafinadamente (LINS, 1980, p. 144). 


\section{CAPÍTULO III}

\section{POESIA E PENSAMENTO EM MARINHEIRO DE PRIMEIRA VIAGEM}

Eles não sabem, nem sonham, que o sonho comanda a vida, que sempre que um homem sonha o mundo pula e avança como bola colorida entre as mãos de uma criança.

(António Gedeão, “Pedra filosofal”. In: Movimento perpétuo, 1956)

\section{III.1. Filosofia e literatura: Uma relação intercomunicante}

A aproximação entre o discurso poético e o filosófico nada representa de novo, pois ocorre desde os primórdios do pensamento ocidental. Esse relacionamento, que se caracteriza por enlaces e desenlaces, em que cada um mantém sua própria especificidade, sem nunca se confundir com o outro, tem sido marcado por certa complexidade ao longo de sua história.

Em Platão (427/8 a.C.-347 a.C), essa associação já aparece conflituosa, e o resultado é que este condena os poetas a não participarem de sua "Politéia" (a polis idealizada que é descrita e defendida em $A$ República). Essa exclusão é por ele justificada pelo fato de os poetas servirem-se da mímesis (imitação das coisas) e de relacionarem-se com o simulacro, o que os impediria de atingir a verdade (eidos) das coisas. Desta forma, eles passariam a ser simples imitadores de cópias, ou de "fantasmas", e, por se relacionarem com coisas enganadoras, deveriam ficar longe da cidade ideal.

É importante destacar que o filósofo grego estava empenhado num projeto utópico (mas pensado com intenção de sua implantação na polis) de formação de um sistema educacional, cujos objetivos fundamentais seriam a justiça e a verdade.

Como assevera Paul Woodruff (citado em LIMA, 2000, p. 31): "Platão tinha duas justificativas, uma pedagógica, outra ético-epistemológica, para sua recusa”, daí o aspecto moral de sua teoria estar tão intimamente ligado à sua oposição à mímesis. E, embora essa 
determinação de Platão encontre coerência dentro de seu próprio sistema filosófico, esse "ressentimento" sempre marcou a relação entre a filosofia e a poesia ao longo da história.

Aristóteles (384 a.C.-322 a.C.) analisa a questão do sentido da mímesis sob um ângulo diferente daquele defendido por seu mestre Platão. Para o Estagirita, a imitação da vida interior dos homens, suas paixões, seu caráter etc., é natural no ser humano, e os homens sentem prazer naquilo que imitam, como expõe na Poética (IV, 1448b4): “Ao que parece, duas causas, e ambas naturais, geraram a poesia. $\mathrm{O}$ imitar é congênito no homem (e nisso difere dos outros viventes, pois, de todos, é ele o mais imitador, e, por imitação, aprende as primeiras noções), e os homens se comprazem no imitado".

Para Aristóteles, o fato poético é livre, não sendo regido pelo real, "mas pelas leis de organização concretizadas na verossimilhança e na necessidade" (BRANDÃO, 1976, p. 30). Por ser "verossímil, a imitação poética apóia-se não na realidade como tal, mas como acontecível; enquanto necessária, a composição poética estabelece sua própria lógica interna, e, conseqüentemente, autonomiza-se em relação à realidade, universalizando-se" (p. 30). O discípulo de Platão, em suas reflexões sobre a tragédia, na conhecida passagem da Poética (IX, 1451b), afirma que "a poesia é algo de mais filosófico e mais sério do que a história", e nisso já podemos avaliar o destaque e a importância que o filósofo atribui ao poeta e à sua arte.

As diferenças entre o pensamento de Platão e o de Aristóteles atravessarão a história da filosofia até Hegel como a disputa da "inteligência, do entendimento contra a imaginação", afirma Benedito Nunes em "Hermenêutica e poesia" (1999, p. 16). E, embora não seja nossa proposta fazer uma avaliação do percurso histórico em que se deu a relação entre o discurso filosófico e o literário, vale destacar um momento em que há uma aproximação marcante entre eles: a época do romantismo e do idealismo alemão nascente (de meados do século XVIII até a primeira metade do século XIX). "É então que, rompendo com a ascendência hierárquica da filosofia, dentro da tradição clássica, os românticos pretendem unir, por intermédio da intuição intelectual e da imaginação, destacadas pelo idealismo de Fichte, filosofia e poesia num gênero misto de criação verbal." (NUNES, 1999, p. 17). A exemplo de Friedrich Schlegel (1772-1829) e Novalis (1772-1801), que encaminham a poesia filosoficamente, F. W. J. Schelling (1775-1854), no Sistema do idealismo transcendental (1800), direciona a filosofia para o poético ou artístico. O que ocorre nesse momento é "uma dupla conversão simétrica - da filosofia em arte e da arte em filosofia [...]. No poeta desponta o filósofo, e no filósofo remanesce o poeta" (id., ibid., p. 17). 
Enquanto no campo da poesia destacava-se sua relação com a filosofia, no campo filosófico efetuava-se "a descoberta do elemento pré-teórico da experiência humana" (id., ibid., p. 18). Vejam-se, em particular, quanto a esse aspecto, as reflexões da filosofia da vida, de Karl Jaspers (1883-1969), filósofo marcadamente existencial, que se aproxima de Schelling, de S. Kierkegaard (1813-55) e da ontologia heideggeriana. Em Heidegger, encontramos uma das fontes do existencialismo defendido por Sartre e da fenomenologia da percepção de Maurice Merleau-Ponty (1908-1961), que, por sua vez, liga a vertente hermenêutica da filosofia da vida à fenomenologia de Edmund Husserl (1859-1938).

"Essa descoberta favorecia a transação da filosofia com a poesia" (id., ibid., p. 18), por isso vamos ver nos livros de Jean-Paul Sartre a preocupação com o dramático da existência humana. Também em sua obra Fenomenologia da percepção (1945), Merleau-Ponty reúne o artístico e o filosófico numa descrição da experiência perceptiva revelada, por exemplo, na pintura de Cézanne.

Entretanto, como assevera Benedito Nunes em "Hermenêutica e poesia" (id., ibid., p. 19), nem o pensamento existencial, nem os derivados franceses da fenomenologia que se abasteceram em Heidegger levaram essa transação a um ponto tão avançado o que se dá na hermenêutica do chamado Heidegger da segunda fase, ou seja, "um intercurso dialogal", que corresponde a um "pensar poético" ou "um poetar pensante". Diferentemente do que sucedera com as teorias do neokantismo e da fenomenologia husserliana, que se preocupavam com uma "ciência rigorosa", "o intercurso dialogal da filosofia em Heidegger não se dá com a ciência, mas com a poesia" (id., ibid.).

Sobre essa relação de diálogo entre filosofia e literatura, comenta Benedito Nunes em "Meu caminho na crítica" (idem, 2005, p. 293): "Essas duas linguagens na maioria das vezes se traspassam em seus próprios componentes extremos, como obras repassadas pela mesma vis poética, formativa: entra o poético na filosofia e entra o filosófico na poesia, e ambas enriquecem-se mutuamente". Ele lembra Juan de Mairena: "Hay hombres, decía mi maestro, que van de la Poética a la Filosofía; outros que van de la Filosofía a la Poética. Lo inevitable es ir de lo uno a lo outro, en esto como en todo" (NUNES, 2005, p. 294). E afirma, destacando, que, apesar dos embates, a filosofia sempre se encontra presente numa determinada crítica, e complementa:

Sejam quais forem, os métodos da crítica literária sempre têm uma maneira $a$ priori, por assim dizer filosófica, de conceber e de avaliar o alcance do texto literário, em função de um fenômeno mais extensivo que o engloba, seja a linguagem, seja a sociedade, seja a história (NUNES, 2005, p. 292). 
Quando se situa diante do texto literário, o crítico-leitor sempre assume a perspectiva de uma determinada linha crítica que se vincula ao mundo no qual está inserido. Mesmo o autor, quando desenvolve sua escrita, revela uma ótica sustentada pela visão filosóficohistórica de seu mundo, e é sob o ponto de vista de uma determinada filosofia que a obra se mantém. Entre vários exemplos, temos Dante (1265-1321), que relacionou a escolástica à Divina comédia (1307), e Lucrécio (c. 98 e 55 a.C.), "que integrou o atomismo de Leucipo (c. 500 a.C.), Demócrito (c. 460-370 a.C.) e Epicuro (341-271 a.C.) ao De Rerum Natura” (id., ibid., p. 293). A esses, Benedito Nunes acrescenta o nome de Goethe (1749-1832), que, ao escrever o seu Fausto (1806 e 1832), incorporou “o panteísmo de Giordano Bruno, o monismo de Spinoza, as mônadas de Leibniz, a idéia estética de Kant e a intuição racional de Fichte" (id., ibid.). E o crítico continua sua exposição, incluindo importantes obras do passado em que essas recorrências são inúmeras. Segundo ele, quando delas nos aproximamos, podemos apreender "uma predisposição filosófica, do mesmo modo que, inversa e complementarmente, filosofias se nos apresentam com acentuado viés literário, a exemplo das filosofias, já em nossa época, de Heidegger, Sartre e Merleau-Ponty (1908-1961)” (id., ibid.), como comentamos anteriormente.

O que se pode constatar dessas reflexões sobre a relação entre o pensamento filosófico e o literário é que, do encontro desses dois campos do conhecimento, surgem resultados enriquecedores tanto para uma quanto para outra área, e, quando os aplicamos ao estudo de um determinado texto, eles determinam uma amplificação no sentido dessa leitura.

\section{III.2. Uma breve incursão no pensamento de Heidegger}

Antes de nos determos em algumas reflexões poético-filosóficas que a leitura de Marinheiro de primeira viagem (1963) suscita, julgamos fundamental fazer uma breve incursão no pensamento de Martin Heidegger (1889-1976). Adotamos esse procedimento, também, nesta última etapa da dissertação, por termos até aqui, exposto as bases teóricas dos autores aos quais recorrermos, para fundamentar nossas análises.

Com uma breve digressão sobre o pensamento de Heidegger, nosso "objetivo é tentar compreender o porquê, o direito, o fundamento e os limites dessa dialogação com a poesia" (NUNES, 1999, p. 20), que se apresenta, no livro que ora analisamos, pois as idéias desse filósofo se nos apresentam como um suporte, para tal reflexão. E como, para tratar dessa questão, o tema "já nos coloca numa fase avançada da filosofia heideggeriana", não podemos 
dar um salto qualitativo em nossas análises, "sem antes compreender o que possibilitou esse caminho e como se delinearam na fase primeira ou preliminar, em Ser e tempo" (id., ibid., p. 20), os conceitos fundamentais do pensamento do autor. Portanto, para acompanharmos como se engendra o ideário de Heidegger, é necessário focalizar seus escritos da primeira fase.

O filósofo alemão faz um percurso reflexivo que passa pela analítica da pre-sença (dasein, ser-ai) até chegar à poesia. Ele encaminha, ao longo de seus trabalhos, suas reflexões ontológicas para o campo da linguagem, o que envolve o problema do ser, seu sentido e a verdade. O ponto de partida é Ser e tempo (1927) - obra que marca uma grande mudança na maneira de abordar a tradição metafísica ocidental, muito embora nos fixemos nas idéias do chamado Heidegger da segunda fase, cujas idéias se destacam em Hölderlin e a essência da poesia (1936) e em A origem da obra de arte (1950).

Em Ser e tempo (1927), Heidegger realiza uma crítica radical à filosofia clássica ao quebrar paradigmas e mostrar a necessidade de se voltar à ontologia para resgatar "o esquecimento do Ser”. A pergunta que se impõe não é o que é o ser, mas qual o seu sentido. Segundo Heidegger, a tradição confundiu "ser" e "ente", e o resultado foi desastroso, pois daí decorreram várias outras complicações, como, por exemplo, a compreesão do ser consistindo em substância e acidente, categorizado e objetivado. O que se impõe é a necessidade de pensar-se o homem como "ente" e como "ser", o que implica o ôntico (o existente concreto) e o ontológico (reflexão do sentido do ser), um questionamento que a filosofia até então deixara de realizar.

Para que se tenha a compreensão do sentido de um ente, é necessário haver uma inicial compreensão do ser, e isso se dá na pre-sença que se distingue de todos os outros entes "pelo privilégio de, em seu ser, isto é, sendo, estar em jogo seu próprio ser" e poder "estabelecer uma relação de ser com seu próprio ser” (HEIDEGGER, 2002, p. 38), que se dá com base na própria existência. Isso se dá, pois lhe é própria "uma compreensão existencial" que se acha pré-delineada em sua constituição ôntica.

A fenomenologia é a ciência dos fenômenos e tem papel fundamental no pensamento do filósofo, e, segundo a visão heideggeriana, em Ser e tempo (2002, p. 65), é preciso partir do fenômeno, é "deixar e fazer ver por si mesmo aquilo que se mostra, tal como se mostra a partir de si mesmo" e que "exprime uma máxima que se pode formular na expressão: 'as coisas em si mesmas!' - por oposição às construções soltas no ar, às descobertas acidentais, à admissão de conceitos só aparentemente verificados, por oposição às pseudoquestões que se apresentam, muitas vezes, como 'problemas', ao longo de muitas gerações”. (p. 57). 
A pre-sença não é intermediária no processo fenomenológico, mas o lugar em que o fenômeno se mostra. A pre-sença "inclui, de maneira igualmente originária, a compreensão de 'mundo' e a compreensão do ser dos entes que se tornam acessíveis dentro do mundo" (HEIDEGGER, 2002, p. 40). Ela é, segundo Heidegger, o ente que só existe compreendendo o ser e que, por isso, pode interpretar tanto o mundo quanto a si mesmo. Ela não parte de um determinado ponto, e daí então surge a compreensão do mundo e de si mesma, há a inseparabilidade entre sujeito e objeto, forma e conteúdo. É um processo de inclusão e adesão sempre antecipados.

Em Ser e tempo, Heidegger trata da questão do Ser e emprega em suas análises do Dasein a fenomenologia hermenêutica, que já se mostra afastada da abordagem de seu mestre, Husserl, para quem o fenômeno constitui-se pela intencionalidade da consciência, que desempenha papel fundamental. A analítica existencial heideggeriana volta-se para as estruturas da existência e destaca-se pela preocupação ontológico-hermenêutica.

Segundo Heidegger, se nos voltarmos para uma análise do passado, na Grécia, veremos que tanto Platão, com seu mundo das "idéias", quanto Aristóteles, com seus conceitos de substância e de categorias, não conseguiram elucidar a questão do ser. O mesmo ocorreu durante o período medieval, em que se "discutiu variadamente o problema, sobretudo nas escolas tomista e escotistas, sem, no entanto, chegar a uma clareza de princípio" (id., ibid., p. 28); muitas "reconstituições" foram realizadas até chegar-se a Hegel, que dá sua versão para o problema. Ele “determina o 'ser' como o 'imediato indeterminado' e coloca essa determinação à base de todas as ulteriores explicações categoriais de sua Lógica". Com isso, ele não se afastou da tradição nem a inovou totalmente, mas permanece na mesma linha "da antiga ontologia, com a diferença de que abandona o problema, já colocado por Aristóteles, da unidade do ser, face à variedade multiforme das 'categorias' reais" (id., ibid., p. 28-9).

Como defende Heidegger: "O conceito de 'ser' é indefinível”, mas, pelo fato de não se poder defini-lo, ele "não dispensa a questão de seu sentido, ao contrário, justamente por isso a exige" (HEIDEGGER, 2002, p. 29). O ser não se manifesta em si mesmo, mas como um ente que não pode ser analisado em termos de simples presença. Ele se dá a partir do Dasein (serai), o único ser do qual se pode investigar o sentido, porque é para ele que as coisas se apresentam, é o lugar da "clareira do ser". Com essa terminologia Heidegger esclarece a posição do ser do homem (Dasein) em face de todos os outros e propõe que se procure, "na analítica existencial da presença, a ontologia fundamental de onde todas as demais podem originar-se" (id., ibid., p. 40). 
Com a recuperação da ontologia, Heidegger pretende fazer com que o homem orientese pela verdade e pela busca do sentido do ser, o que não tenciona a filosofia moderna, que desenvolveu um pensamento voltado para o conhecimento, ou a filosofia da consciência, a qual encaminhou o indivíduo para a ilusão. A questão heideggeriana da verdade remonta a Platão, e é um tema desenvolvido na obra $A$ doutrina de Platão sobre a verdade. O filósofo grego defendia a idéia da verdade como adequação do intelecto a uma determinada coisa, com a noção de "visão correta" (orthótes). Fundamentada em seu Mito da Caverna, essa noção seria a responsável pela herança metafísico-epistemológica que ocasionou a perda da possibilidade de captar-se a manifestação (revelação) do ser.

Em sua análise, o filósofo alemão dá ao tema do tempo um destaque especial, e afirma que a temporalidade não é exterior ao homem, é o sentido da pre-sença e uma dimensão fundamental do ser humano: "o tempo é o ponto de partida do qual a pre-sença sempre compreende e interpreta implicitamente o ser" (p. 45). Mais especificamente, é a temporalidade que está intimamente ligada ao homem (Dasein), pois ele é um existente, justamente por essa ligação com o tempo, que é o modo de ser da pre-sença. Só “apropriandose positivamente do passado é que ela pode entrar na posse integral das possibilidades mais próprias de seu questionamento" (p. 49). As possibilidades futuras aparecem-lhe e estimulamno a ir além, em busca de seu futuro, o "poder-ser", que o caracteriza como um "projeto" que sempre pode ser retomado.

A vida humana pode se dar na inautenticidade ou na autenticidade. A inautenticidade ocorre quando há o distanciamento do homem de sua própria condição humana, quando ele, por não ter consciência dela, deixa-se levar pelos acontecimentos. A vida autêntica é a consciência que o homem tem de sua condição de ser-para-a-morte: ele interessa-se pelo mundo e pelas coisas e vive envolvido na construção de seu destino.

O tema da morte, segundo Heidegger, está presente no homem e o conduz para o nada da existência, é um evento do qual não se pode escapar. Podemos escolher muitas coisas, mas não deixar de morrer, que é uma permanente possibilidade, que pode, até mesmo, aniquilar todas as outras possibilidades. A morte é a impossibilidade do Dasein, o qual pode escolher entre o cotidiano e o esquecimento; ou superar a angústia e transcender o mundo e a si mesmo, com a compreensão antecipada da morte como possibilidade da existência.

As questões que envolvem a historicidade e a temporalidade do ser, tão amplamente desenvolvidas por Heidegger em Ser e tempo, implicam uma investigação das estruturas básicas da existência humana. Esse tipo de preocupação foi a da primeira fase do filósofo, em que ele procurou "o sentido do ser", e, para isso, era necessário partir de uma analítica 
fundamental. Em sua "segunda fase", a preocupação está em meditar sobre a verdade, com isso ele imprime a chamada viragem de seu pensamento, o que não quer dizer uma inversão ou negação, mas um aprofundamento da temática desenvolvida em Ser e tempo. Nessa sua segunda fase, o filósofo alemão dará importância à palavra de onde deve provir a investigação e deixará de lado uma certa investigação incisiva, para ceder espaço à sua escuta paciente. $\mathrm{E}$ sua busca passa a ser a da verdade que não se pauta pelo conceito tradicional de adequação de uma representação a seu objeto, mas as condições procuradas, segundo ele, repousam em algo mais originário, que é a verdade do ser.

Um outro trabalho que marcou mudança de foco no pensamento heideggeriano, foi o seu encontro com a poesia em Hölderlin expresso em Hölderlin e a essência da poesia (1934), sem que suas reflexões anteriores tivessem perdido a importância. Segundo Werle, (2005, p. 17), o filósofo percebeu que as suas análises do dasein "ficavam excessivamente ligadas à cotidianidade mediana, não sendo capazes de realizar o salto para dentro do problema do ser" (p. 17). Mesmo a questão da autenticidade "não conseguia enfrentar a manifestação do ser pelo seu lado mais oculto, [...], a verdade mesma, a essência da verdade enquanto verdade da essência". O que ocorreu é que a temática existencial acabou "ofuscando" o questionamento "mesmo da verdade". "Assim, ele se viu na necessidade de dar um passo mais adiante, na direção de um encontro com a poesia, de modo que pudesse efetivamente transitar pelas regiões tortuosas e inusitadas do ser" (WERLE, 2005, p. 12). E, embora Heidegger perceba "que a questão em si não tem solução, [...] ela deve ser sobretudo cultivada e mantida acesa como tarefa constante do pensamento" (p. 34).

Em A origem da obra de arte (1950), Heidegger aborda a natureza da obra de arte: empreende um percurso existencial e defende que a essência da arte é a poesia, e a essência da poesia é a verdade (alétheia), como o acontecimento do mundo. Na poesia acontece a desocultação do ente e é onde as coisas aparecem e adquirem significado, por uma relação de participação do artista na obra e da obra no artista. Há uma relação de co-participação, por isso um não é sem o outro. Na obra de arte o mundo ganha visibilidade, razão pela qual é ela um lugar de acontecimento da verdade. "A obra de arte abre à sua maneira o ser do ente" (HEIDEGGER, 1991, p. 30), ao desocultar a verdade que o ente abriga ela instaura um mundo e o mantém aberto (p. 35). Os gregos chamavam de physis ${ }^{1}$ ( $\left.\varphi v ́ \sigma ı\right)$ o que Heidegger chamou "terra", que é inseparável do mundo, embora com ele não se confunda: "O mundo funda-se na terra, e a terra irrompe através do mundo" (p. 38).

\footnotetext{
${ }^{1}$ Physis é uma palavra grega que significa a realidade primeira e última de tudo o que existe.
} 
Martin Heidegger, em A origem da obra de arte (HEIDEGGER, 1991, p. 58), afirma: "Toda a arte, por permitir a adveniência da verdade do ente como tal, é na sua essência Poesia”. Seu questionamento inicial visa a encontrar o caminho a partir e através do qual "uma coisa é o que é, e como é". Ele chega à conclusão de que a "origem de algo é a proveniência da sua essência" (id., ibid., p. 11), que "surge a partir e através da atividade do artista" e afirma que obra e artista estão intimamente ligados: um não é sem o outro, e ambos se sustentam em função de "um terceiro, que é o primeiro, a saber, graças àquilo a que o artista e a obra de arte vão buscar, graças à arte" (id., ibid.). E, para estarmos seguros de que realmente encontramos "a essência da arte, que reina realmente na obra, procuramos a obra real e perguntamos à obra o que é e como é" (id., ibid., p. 12), pois todas as obras têm essa concretude e o caráter de ser coisa. Como comenta Heidegger: "Os hinos de Hölderlin estavam embrulhados na mochila do soldado, tal como os objetos da limpeza. Os quartetos de Beethoven estão nos armazéns das casas editoriais, tal como as batatas na cave" (id., ibid., p. 13). Todas as obras artísticas carregam “o caráter coisal da obra de arte" (id., ibid.), cuja experiência estética não pode "contornar" esse caráter de coisa que tem uma determinada obra. Ela nos dá, porém, a conhecer um outro, este “outro, que lá está, é que constitui o artístico" (id., ibid.); ela é alegoria e reúne-se, "na obra de arte, a algo de outro" e torna-se símbolo. Alegoria e símbolo formam uma unidade na obra e "essa unidade, que se reúne com algo de outro, é que é o elemento coisal na obra de arte" (id., ibid.). Ao nos situarmos diante do quadro que retrata um par de sapatos de camponesa, "a obra de arte nos revela toda a realidade de um par de sapatos" (NUNES, 1999, p. 96).

Como Heidegger comenta: um par de sapatos que nem ao menos sabemos onde se encontram, aos quais nem sequer vemos "presos torrões de terra, ou do caminho do campo, algo que possa denunciar a sua utilização. Um par de sapatos de camponês e nada mais. Todavia...” ao olharmos seu estado de utilização, compreendemos que em seu interior, no

[...] gasto dos sapatos, fita-nos a dificuldade e o cansaço dos passos do trabalhador. Na gravidade rude e sólida dos sapatos está retida a tenacidade do lento caminhar pelos sulcos que se estendem até longe, sempre iguais, pelo campo, sobre o qual sopra um vento agreste. No couro, está a umidade e a fertilidade do solo. Sob as solas, insinua-se a solidão do caminho do campo, pela noite que cai. No apetrecho para calçar impera o apelo calado da terra, a sua oferta do trigo que amadurece e a sua inexplicável recusa na desolada improdutividade do campo no Inverno. Por este apetrecho passa o calado temor pela segurança do pão, a silenciosa alegria de vencer uma vez 
mais a miséria, a angústia do nascimento iminente e o tremor ante a ameaça da morte (HEIDEGGER, 1991, p. 25).

Com esse exemplo, Heidegger mostra-nos que no quadro de Van Gogh o mundo é instaurado. É na concretude da coisa que a compreensão se dá, pois a obra origina-se do mundo e o revela, pois o quadro é uma abertura, em que se revelam a terra e o mundo, onde o esforço do camponês pela sobrevivência. "Podemos ver tudo isso no mesmo quadro, e nossa visão está sendo dirigida pelo ser do utensílio que a obra revela" (NUNES, 1999, p. 102).

Heidegger escolhe como exemplo um apetrecho conhecido, os sapatos da camponesa, retratados pelo pintor Van Gogh, e ele se pergunta o que é que há de especial no velho par de sapatos, uma vez que todas as pessoas sabem de que são feitos e para que servem. E, nessa pintura do pintor holandês, nada além dos sapatos se apresenta, nem o local onde eles podem se encontrar e nem o nome da pessoa a quem eles pertencem.

Os sapatos do camponês são um apetrecho que pertence à terra e ao mundo da camponesa, e por isso ele é um repousar-em-si-mesmo, e é em sua solidez de apetrecho que estão todas as coisas conjugadas (HEIDEGGER, 1991, p. 26), mas, quando nos pomos diante do quadro de Van Gogh, descobrimos “o 'ser-apetrecho' do apetrecho” (id., ibid., p. 27). "A obra de arte fez saber o que o apetrecho de calçar na verdade é” (id., ibid.); não foi preciso nenhuma dissertação, nada. A obra de arte falou por si, independentemente de qualquer descrição. "A pintura de Van Gogh constitui a abertura que o apetrecho, o par de sapatos da camponesa, na verdade é. Este ente emerge no desvelamento de seu ser." (HEIDEGGER, 1991). Heidegger diz que os gregos a isso chamavam de alétheia, e isso significa que está em obra "um acontecer da verdade", pois na obra de arte "põe-se em obra a verdade do ente" (id., ibid.).

Com essas reflexões, Heidegger destaca não o Belo e a Beleza, mas a "Verdade". Isso se dá não porque o quadro do pintor holandês copie fielmente um par de sapatos de camponês, mas sim porque consegue a "reprodução da essência geral das coisas" (id., ibid., p. 28), que é a verdade de "algo intemporal e supratemporal" (id., ibid., p. 29). Na "abertura do ente em seu ser: o acontecimento da verdade" (HEIDEGGER, 1991, p. 29). "O caráter coisal na obra não deve ser negado; mas este caráter coisal, se pertence ao ser-obra da obra, tem de pensar-se a partir do caráter de obra da obra" (id., ibid., p. 30). A obra de arte desvela o ser do ente, ela o desoculta, poeticamente. 
Essas questões filosóficas sobre a origem da obra de arte e suas implicações, realizadas por Heidegger, ajudam-nos a refletir sobre a "essência poética" que se apresenta em Marinheiro de primeira viagem que coloca em evidência o mundo-da-obra. São essas questões apresentadas, até aqui, que sustentarão, a seguir, as nossas reflexões poéticofilosóficas em Marinheiro de primeira viagem.

\section{III.3. Uma leitura poético-filosófica de Marinheiro de primeira viagem}

O que pode parecer "título de uma tematização: poesia e pensamento, mostra-se como a inscrição em que o destino de nossa presença de há muito está inscrito. A inscrição assinala a co-pertença de poesia e pensamento" (2003, p. 188), afirma Heidegger. Essa ligação é muito antiga e se perde no tempo imemorial, e "poesia e pensamento são uma extraordinária saga do dizer" (p. 189), que diz melhor e se capta mais facilmente na essencialidade da poesia.

Heidegger afirma em $A$ caminho da linguagem (1959) que "deixamo-nos dizer pelo poeta e com ele o que na poética da poesia é digno de se pensar". Continua ele: "Deixar dizer o que é digno de se pensar significa - pensar. Escutando o poema, pensamos a partir da poesia. Desse modo, é a poesia, é o pensamento" (2003, p. 188).

À primeira vista, ao nos acercarmos do livro Marinheiro de primeira viagem, a impressão que se tem é que o autor o organizou a partir de fragmentos narrativos, sem que um evento tenha qualquer relação com outro, e é assim que foi sempre visto pela crítica. Porém, foi possível, porém, colocar em evidência a forma circular em que as narrativas estão inscritas, em cuja visibilidade pôde-se captar sua unidade formal, que acabou por remeter ao conteúdo mítico que lá está, na figura do poeta Orfeu. Com a iluminação que esses eventos proporcionaram à leitura desse livro de Osman Lins, pudemos constatar que sua forma e seu conteúdo transmitem mais do que lembranças isoladas ou distribuídas aleatoriamente, o que já tivemos a oportunidade de demonstrar com as ligações entre as narrativas, a partir de suas relações de sentido e literais, quando tratamos desse tema, no Capítulo I, item 5: Um projeto gráfico de Marinheiro de primeira viagem.

As repetições de palavras, períodos e frases em diferentes fragmentos os une e cria vínculos narrativos entre eles, além de que, a disposição como estão colocados certos fragmentos indica que eles não estão ali como "meras coisas". Aliás, como assevera Heidegger, ao tratar alguma coisa como "mera", significa despojá-la do caráter de serventia (1991, p. 22) que ela pode ter. Em Marinheiro de primeira viagem esse caráter de "mera 
coisa" não pode ser aplicado os fragmentos e ao lugar ocupado por eles, mesmo o aparentemente isolado "Mensagem" (p. 66), com apenas três linhas, está relacionado com o anterior, como também já expusemos no Capítulo I, item 5.

Podemos, também, observar que o nome Eurídice repete-se nos fragmentos: "Eurídice" (id., ibid., p. 66), "Perguntas" (id., ibid., p. 107) e "O Anti-Orfeu" (id., ibid., p. 142), em outros, como "Noite“(id., ibid., p. 56), Clássico" (id., ibid., p. 93) e "Exodus" (id., ibid., p. 110), alguns deles fazem referências intertextuais e nominais ao mito de Orfeu, como já foi detalhado no Capítulo II. Um outro reparo: no livro é particularmente visível um procedimento próprio da contextualidade, que é a forma circular em que o livro está organizado. Ora, essa é a marca por excelência do tempo mítico. O fechamento do círculo dáse ligado ao nome de Orfeu, entre o fragmento inicial (id., ibid., p. 7) e o "O Anti-Orfeu" (id., ibid., p. 142), que é o que encerra o livro. Além disso, pelo fato da narrativa inicial não ter título, a ligação à última é realizada de maneira perfeita, sem ruptura, assinalando, com isso, a união entre o princípio e o fim das experiências da viagem. Essa organização formal realizada pelo autor acentua a sua coesão estrutural.

Todos esses indícios que acentuamos ao longo de nossa dissertação encaminharam-nos para uma análise do livro sob o ponto de vista da hermenêutica que, enquanto técnica ou arte da exegese, defende "o princípio da contextualidade, ou seja, a correlação no texto entre o sentido das partes e o sentido do todo, pois que o entendimento deste precede o das partes, que, por sua vez, compreendidas, interferem na compreensão do todo", segundo Benedito Nunes (1999, p. 57).

Diante das justificativas, acima destacadas, viabilizou-se a realização de uma exegese de Marinheiro de primeira viagem, relacionada ao mito do poeta Orfeu, como um elemento que potencializa a poética da obra e viabiliza uma leitura sob o ponto de vista de sua unidade poética. Não podemos esquecer que, quando falamos de mito, falamos de narrativa, falamos de poesia. Além disso, o apelo estratégico ao nome do lendário Orfeu deixa transparecer o desejo da busca das origens e das fontes culturais, que tem na imagem desse poeta, uma referência que não pode ser negligenciada. Além disso, o mito é a forma mais originária de conhecimento do mundo. É a instância na qual falam a emoção e os sentimentos, quando se trata de conceber uma realidade. Ele não é uma invenção ou uma ilusão, mas uma categoria de pensamento que procura dar conta de uma determinada situação que não podemos abarcar racionalmente.

No mito está envolvida uma visão global e unitária das coisas e do mundo, como a que traduz o episódio do poema homérico Ilíada narrado no Canto XVIII, 470 et seq.. Nesse canto 
o poeta Homero narra os detalhes da fabricação, pelo ferreiro divino Hefesto, das armas do grande herói Aquiles. Ele havia ficado sem elas, pois as emprestara ao amigo Pátroclo, que acabou morrendo em combate e conseqüentemente perdeu as suas armas. O grande Aquiles, porém, precisava voltar à guerra, pois, sem a sua participação, os gregos não venceriam a batalha contra os troianos. Sua mãe, a ninfa Tétis, solicita ao deus da forja, Hefesto, que fabrique outras. E assim, diante da fornalha, o ferro passa a ser esculpido: o escudo possuía cinco camadas, em que foi gravada "a ampla terra e o mar vasto, o firmamento, o sol claro e incansável, a lua redonda e as numerosas estrelas, que servem ao céu de coroa”. E, não só isso, ainda gravou uma reunião de homens famosos e todas as constelações do céu, e duas cidades em que numa delas se celebrava um feliz casamento, em que os convidados entoavam um hino de alegria. Também flautistas apareciam numa alegre roda em que jovens dançavam. Nas casas, viam-se muitas mulheres que apreciavam um cortejo. Registra, também, cena no mercado, em que homens negociavam e exigiam a presença de um juiz para que ele arbitrasse e pusesse fim à contenda que surgiu entre eles. Os mais velhos foram colocados num recinto sagrado com seus cetros. Também as vinhas foram gravadas, carregadas de belíssimos frutos. Muitas outras coisas o ferreiro divino esculpiu no escudo de Aquiles e, por fim, na orla externa colocou o rio Oceano, que, segundo a mitologia, circunda toda a terra.

O escudo de Aquiles é uma alegoria e um símbolo, nele estavam registrada toda a vida do povo grego, não como algo externo que pode ser representado. O guerreiro é aquilo tudo, e aquilo tudo é o guerreiro. Hefesto só pode esculpir tal armadura por essa aderência entre o herói, seu escudo e seu mundo. Não havia distância entre o objeto e sua representação, um era o outro.

Em Marinheiro de primeira viagem, ressaltamos o desejo de totalidade e de transcendência do autor-viajante-narrador, com base nas declarações do próprio escritor, que afirmou: “enquanto romancista, eu aspiro a uma visão cósmica. Se há alguma coisa de que é necessário o leitor entrar consciente diante de um texto meu é de que eu não estou aspirando a dar uma visão apenas do homem brasileiro. [...] o que eu procuro dar nos meus textos [...] é uma visão [...] do cosmos" (LINS, 1979, p. 218). E, ainda sobre a sua concepção como romancista, ele diz: "como romancista, há um grande componente no meu espírito da visão mítica do mundo. [...] enquanto romancista, sou um homem mítico" (id., ibid., p. 218).

Diante dessas declarações do autor de Marinheiro de primeira viagem somos remetidos diretamente ao dasein (pre-sença) heideggeriano, em que o filósofo defende a inseparabilidade entre o sujeito e o objeto, entre o escritor e sua obra. Essa relação de unidade entre o trabalho do escritor e a sua vida pessoal foi uma trilha que viemos traçando desde o 
primeiro capítulo de nossa dissertação, embora ressaltando que o nosso interesse não era o foco psicológico, mas o ideário formador e que marca o trabalho do autor. Pusemos em evidência a determinação de Osman Lins em assumir a sua função de escritor, a sua busca literária que "seria construir com a imaginação um rosto que não existe", que foi a busca pelo rosto de sua mãe, que ele não conheceu, como ele mesmo afirmou. Também se acha integrada nesse processo, a convivência familiar e as influências narrativas do tio e com as formas geométricas, na fase em que ele era criança e depois, na fase adulta, com as leituras de Matila Gika e a viagem que deu origem ao livro. Todas essas questões apontadas corroboram a ligação entre a obra e a vida pessoal do escritor. Daí a necessidade que vimos, em mostrar as implicações da vida de Osman Lins e muito das suas idéias reveladas em sua escritura - o que forma uma unidade de atuar e de ser-no-mundo.

Em Marinheiro de primeira viagem procuraremos destacar a essência artística que envolve a obra, relacionada ao mito e portanto enquanto relação poética. Essência, aqui, não tem relação com o sentido que lhe dá Platão (idéia), mas "esse outro, que lá está, é que

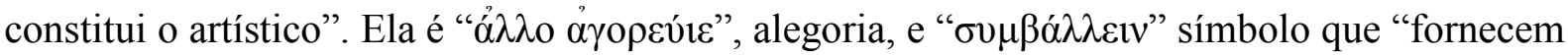
o enquadramento em cuja perspectiva se move desde há muito a caracterização da obra de arte [...] à qual adere ainda algo de outro, só então é possível decidir se a obra é, no fundo, algo de outro" (1991, p. 13-4), o que faz do livro Marinheiro de primeira viagem uma obra poética, isto é o que lhe dá a consistência artística.

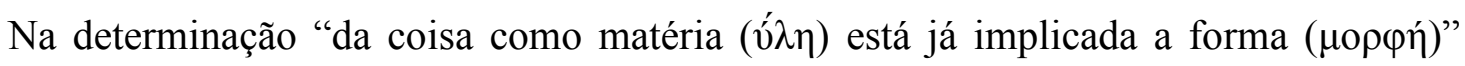
(id., ibid., p. 19), que em Marinheiro de primeira viagem identificamos como sendo a "matéria", o mito de Orfeu que imprime por sua força implícita a poesia ao Marinheiro..., e como "forma", o círculo, que é a forma mítica por excelência, aquela em que Osman Lins organizou as suas lembranças vividas pelo viajante-autor-personagem.

Mas, se a matéria e a forma fossem suficientes para determinar o valor poético da obra em questão, nós estaríamos implicando que os compostos matéria e forma, sujeito e objeto são suficientes na composição do objeto artístico, e não teríamos acrescentado nada em relação à concepção de Heidegger sobre a origem da obra de arte em Marinheiro de primeira viagem.

Diante das questões referidas acima, nos colocamos diante da pergunta de Heidegger em $A$ origem da obra de arte (1950): "Para encontrar a essência da arte, que reina realmente na obra, procuramos a obra real e perguntamos à obra o que é e como é” (HEIDEGGER, 1991, p. 12). E sobre essa questão, ele irá exemplificar com o par de sapatos de camponês, 
pintados por van Gogh, como expusemos no item anterior de nosso trabalho, mas que convém repetir alguns pontos.

No caso dos sapatos do camponês de van Gogh, no "apetrecho para calçar impera o apelo calado da terra, a sua muda oferta do trigo que amadurece e a sua inexplicável recusa na desolada improdutividade do campo no inverno. Por este apetrecho passa o calado temor pela segurança do pão, [...]" (1991, p. 25). No quadro de van Gogh os sapatos pintados remetem à terra e ao mundo, em Marinheiro de primeira viagem o poeta nos liga também à terra e ao mundo, em que o homem funda sua maneira de o habitar. Dois caminhos diferentes, mas que conduzem à mesma terra e ao mesmo mundo. Em ambas as obras, há o desvelamento do ente, que os gregos "chamavam de á $\lambda \hat{n} \theta \varepsilon ı \alpha$ " (verdade). No par de sapatos de camponês há a "clareira de seu ser" (abertura do ente em seu ser), em que se instaura um mundo.

Em Marinheiro de primeira viagem a matéria e a forma poética em que as narrativas se apresentam, nos remetem a algo que pertence à terra e ao mundo, que é a experiência do homem como um ser que faz parte da natureza, mas também como um ser histórico, como um ser que tem a possibilidade de imprimir ao mundo a sua forma própria de ser, interferindo, construindo, criando as suas obras, que são nada menos que o reflexo de sua forma de estar no mundo - a condição histórica e temporal do ser humano e o seu desejo de transcendência no mundo.

A palavra poética dada no mito de Orfeu revela essa originariedade da história e da temporalidade humana. Numa explicitação intensa, como memória cultural, podemos ver elencadas as formas mais criativas de apresentação. Ao longo dos fragmentos, vemos os temas - Orfeu, Homero, Virgílio, Dante, Catedral de Saint-Étienne, Jean Cocteau, Goya, Rodin, Catedral de Notre-Dame, Gagarin, Aeroporto, Cézanne, Relatos de saudade, Reflexões no Louvre, Adeus, Viagens de trem, Uccello, Raphael, Espanha, Aniversário, Veneza, Nápoles, Galleria degli Uffizi, Florença, Paris, Notícias do cotidiano - desfilarem ao longo das narrativas osmanianas. E poderíamos continuar elencando um número imenso de eventos que são assinalados em Marinheiro de primeira viagem.

Nós que vivemos sob a égide da cultura ocidental somos tudo isso, temos aí, os destaques de nossa história e de nossa cultura. A questão da temporalidade humana e sua historicidade estão presentes ao longo das narrativas de Marinheiro... Destacamos o fragmento "Saint-Étienne", para podermos apreciar a forte ligação do viajante com o passado, e coloca em evidência a temporalidade humana, como segue: 
Sorve a claridade desta abside, que lhe detém os passos. A vida de São Nicolau, de Maria Egipcíaca, a história de Maria Madalena, de José e os irmãos, a parábola do Bom Samaritano, do Filho Pródigo, outras, ali foram estampadas, juntamente com vibrantes cenas de trabalho (dos tanoeiros, padeiros, carpinteiros, entalhadores de pedra, peleiros etc., cujas corporações doaram o esplêndido conjunto), em flagrantes de um poder de síntese espantoso. Contempla as miúdas figuras, incompletas e rústicas, mas candentes na sua ríspida simplicidade, e vividas, livres, em meio ao excesso de ornamentos, de bordaduras que cercam os medalhões nos quais elas se inscrevem. Se as esquece, se abstrai, ante os vitrais, a biografia ou parábola representadas, seu objetivo edificante, se não vê mais os personagens, suas atitudes, seus rostos, as pregas dos seus mantos, então a beleza das cores se destaca, autônoma - e o maravilhamento não decresce. Sente-se ligado aos homens de há 700 anos, que teceram essas ogivas de chumbo, vidro e luz. Que há, pergunta, nestes vitrais do século XIII, que os faz superiores aos dos séculos XV e XVI? Por que estes últimos, imitando com servidão crescente a 'natureza', extraviaram-se, parecendo hoje autênticos malogros? Seria a recusa, ou o desconhecimento, das limitações inerentes ao seu meio de expressão, que fez os vidraceiros mais recentes desdenharem os exemplos de seus predecessores e criarem um tipo de vitral sem flama, vazio na sua exatidão? E por que desenhos como estes, ingênuos, apenas sugeridos, podem libertar, em nós, potências que um desenho rigoroso deixará para sempre indiferentes? Por que sorrimos nos museus de cera? Por que estremecemos, se postos ante um afresco de Giotto? Que nostalgia temos nós de um mundo que, segundo as aparências, não existe? - e que, mesmo se com ele nos defrontamos pela primeira vez, levanta em nós uma dupla alegria, a de descobrir, a de reencontrar? (LINS, 1980, p. 11-2).

Heidegger afirma que a obra de arte pertence ao campo "aberto por ela própria" (id., ibid., p. 32), razão pela qual ela advém, nessa abertura e instala um mundo. No caso de Marinheiro de primeira viagem, a linguagem mítica que recobre as narrativas e toda a relação dialogal com o passado cultural do mundo ocidental está ali muito bem representada em toda a bagagem do autor que se revela na intertextualidade com que ele envolve seus relatos. Eles dizem, artisticamente, dos feitos humanos, e o dizer artístico é Poesia e esta é a clareira da verdade.

Osman Lins foi um autor que não fez concessões quanto à qualidade de sua expressão literária e Marinheiro de primeira viagem tem o poder de tirar-nos do habitual do mundo, mas ao mesmo tempo revelar o mundo. Segundo o filósofo alemão (id., ibid.), essa é a característica da obra artística, ela tem o poder de "alterar as nossas relações habituais com o mundo e a terra e, a partir de então, suspender o comum fazer e valorar, conhecer e observar, para permanecer na verdade que acontece na obra", mas isso é a marca daquilo que tem o poder de arrebatar-nos e situar-nos de frente ao que somos. 


\section{CONSIDERAÇÕES FINAIS}

Por mais que busquemos aprofundar-nos e penetrar nas camadas textuais que envolvem uma obra literária, nunca a abarcaremos plenamente, pois, no fundo, ela nunca se entrega, principalmente em se tratando de uma obra composta por 202 fragmentos, cada qual revelando particularidades muito especiais, exigindo uma tarefa exploratória que se torna um desafio constante para os leitores, dada a sua plurivocidade discursiva.

Em função da complexidade do livro, esta dissertação dedicou-se a realizar um trabalho de análise de Marinheiro de primeira viagem, primeiramente voltado para seus laços com a vida do autor, em que procuramos seguir as linhas que nos levaram até sua fatura. Esforço esse, que consumiu grande parte do tempo destinado ao trabalho, devido às freqüentes consultas ao arquivo Osman Lins (sediado no IEB-USP), mas que julgamos fundamental, devido à reduzida fortuna acadêmica que envolve esse livro do autor. Numa segunda etapa, procuramos destacar sua poética marcadamente intertextual, como memória da literatura, e aí destacamos a relação estreita dessa obra com o mito do cantor-poeta lendário Orfeu, que foi a abertura para iniciarmos uma leitura poético-filosófica, numa última etapa do trabalho. Afirmamos que foi apenas um começo, pois esse é um empreendimento que requer um outro empenho e um outro tempo disponível para sua realização, além do aprofundamento, no gênero literatura de viagem.

Talvez seja desnecessário afirmar que não pretendemos, de maneira alguma, esgotar o tema, muito pelo contrário, nossa intenção é contribuir para que haja maior divulgação desse Marinheiro de primeira viagem, dada a sua importância estética no conjunto dos trabalhos de Osman Lins, que, fiel a seus princípios de escritor, não procurou "facilitar" sua leitura. Ao contrário, ele dignificou o leitor, ao disponibilizar-lhe um trabalho de alto valor estético e intelectual.

Quando Osman Lins afirmou ser seu desejo que o leitor procurasse esse livro para ler uma obra literária, não exagerou, nem se equivocou. Ele é um livro que decorreu da viagem de seu autor, mas que não foi escrito para servir de guia turístico a seu leitor. Pudemos constatar, porém, que ele é um guia importante para aquele leitor que pretenda sentir o mundo pela sensibilidade e pela experiência de um artista crítico, engajado com o mundo, com sua gente e sua história. 


\section{Referências bibliográficas}

\section{De Osman Lins:}

LINS, O. O visitante. Rio de Janeiro: José Olympio, 1955.

. Guerra sem testemunhas: O escritor, sua condição e a realidade social. São Paulo: Martins, 1969, $285 \mathrm{p}$.

. Avalovara. São Paulo: Melhoramentos, 1973.

$\overline{1974 .}$

• "O tempo em 'Feliz aniversário"”. Colóquio/Letras, Lisboa, 19, p. 16-22, maio de . Lima Barreto e o espaço romanesco. São Paulo: Ática, 1976.

. Do ideal e da glória: Problemas inculturais brasileiros. São Paulo: Summus, 1977.

. Casos especiais de Osman Lins: A ilha no espaço, Marcha fúnebre, Quem era Shirley Temple? São Paulo: Summus, 1978, 126 p.

. "Domingo de Páscoa". Status, São Paulo, nº 45, abril de 1978.

1979.

. Evangelho na taba: Outros problemas inculturais brasileiros. São Paulo: Summus, . Marinheiro de primeira viagem. São Paulo: Summus, 1980.

. "Lamentação tranviária”. In: COUTINHO, E. (Org.). Presença poética do Recife. Rio de Janeiro/Recife: José Olympio/Fundarpe, 1983. Originalmente publicado no Suplemento Literário do Diário de Pernambuco, em 10 de janeiro de 1954.

. A rainha dos cárceres da Grécia. Rio de Janeiro: Guanabara, 1986.

. Retábulo de Santa Joana Carolina. São Paulo: Loyola/Giordano, c. 1991 [1988] [1 ${ }^{\text {a }}$ ed. em 1966]. 
. Lisbela e o prisioneiro: Comédia em três atos. São Paulo: Scipione, 1994a.

. Nove, novena. $4^{\mathrm{a}}$ ed. São Paulo: Companhia das Letras, 1994b.

. Os gestos. $3^{\mathrm{a}}$ ed. São Paulo: Moderna, 1994c (Col. Veredas).

. A ilha no espaço. São Paulo: Moderna, 1997.

. O fiel e a pedra. São Paulo: Círculo do livro, s.d.

LINS, O.; LADEIRA, J. de G. La Paz existe? São Paulo: Summus, 1977.

\section{Sobre Osman Lins:}

ALVES, L. "Com a mesma paixão e fé". Diário Oficial. Estado de Pernambuco, Recife, ano XII, maio/junho de 1998, p. 12 (Suplemento Cultural, "O mundo das palavras, as palavras do mundo, ensaios e depoimentos revisitam cosmos e linguagem de Osman Lins vinte anos depois da sua morte").

ANDRADE, A. L. Osman Lins: Crítica e criação. São Paulo: Hucitec, 1987.

. "A palavra ética contra a sociedade anestésica". In: Diário Oficial. Estado de Pernambuco, Recife, ano XII, maio/junho de 1998, p. 19 (Suplemento Cultural, "O mundo das palavras, as palavras do mundo, ensaios e depoimentos revisitam cosmos e linguagem de Osman Lins vinte anos depois da sua morte").

. "Entre feitiço e fetiche". In: Cult-Revista Brasileira de Literatura, São Paulo, no 48,

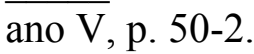

ARAÚJO, B. "No portão de embarque". In: Diário Oficial. Estado de Pernambuco, Recife, ano XII, maio/junho de 1998, p. 11 (Suplemento Cultural, "O mundo das palavras, as palavras do mundo, ensaios e depoimentos revisitam cosmos e linguagem de Osman Lins vinte anos depois da sua morte").

ARAÚJO, R. "Labirinto narrativo". In: Cult-Revista Brasileira de Literatura, São Paulo, no 48, ano V, p. 60-1. 
ARTE e literatura: Osman Lins, 80 anos. Outra Travessia - Revista de Literatura, Florianópolis, $\mathrm{n}^{\mathrm{o}} 4,1^{\circ}$ semestre de 2005 . Número especial.

BARBOSA, J. A. “As tensões de Osman Lins”. In: Diário Oficial. Estado de Pernambuco, Recife, ano XII, maio/junho de 1998, p. 20 (Suplemento Cultural, "O mundo das palavras, as palavras do mundo, ensaios e depoimentos revisitam cosmos e linguagem de Osman Lins vinte anos depois da sua morte").

CARIELLO, G. "Escrever é esquecer - Poéticas: Pessoa, Borges, Osman Lins". Comunicação apresentada ao V Congresso da Associação Portuguesa de Literatura Comparada, Faculdade de Letras da Universidade de Coimbra, em Portugal, $1^{\text {o }}$ a 4 de junho de 2004.

CARONE, M. “Avalovara (Precisão e fantasia)”. Literatura e Sociedade, São Paulo, 20012002, p. 276-81.

CARTAXO, M. de F. P. de M. "Arquitetura e fantasia em Osman Lins". In: Diário Oficial. Estado de Pernambuco, Recife, ano XII, maio/junho de 1998, p. $24-5$ (Suplemento Cultural, "O mundo das palavras, as palavras do mundo, ensaios e depoimentos revisitam cosmos e linguagem de Osman Lins vinte anos depois da sua morte").

CLÁUDIO, J. "Ele me chamava "pintor de passarinhos"”. In: Diário Oficial. Estado de Pernambuco, Recife, ano XII, maio/junho de 1998 (Suplemento Cultural, "O mundo das palavras, as palavras do mundo, ensaios e depoimentos revisitam cosmos e linguagem de Osman Lins vinte anos depois da sua morte").

DALCASTAGNÈ, R. "Mistérios e buscas de Avalovara". In: Diário Oficial. Estado de Pernambuco, Recife, ano XII, maio/junho de 1998, p. 26 (Suplemento Cultural, "O mundo das palavras, as palavras do mundo, ensaios e depoimentos revisitam cosmos e linguagem de Osman Lins vinte anos depois da sua morte").

2000 .

- A garganta das coisas:Movimentos de Avalovara, de Osman Lins. Brasília: UnB,

DIAS, M. T. de J. . "Fortuna crítica". In: Cult - Revista Brasileira de Literatura, São Paulo, $\mathrm{n}^{\mathrm{o}} 48$, ano V, p. 56-9.

DOURADO, M. L. “Como Osman Lins descobriu a literatura”. In: Diário Oficial. Estado de Pernambuco, Recife, ano XII, maio/junho de 1998, p. 16-7 (Suplemento Cultural, "O mundo das palavras, as palavras do mundo, ensaios e depoimentos revisitam cosmos e linguagem de Osman Lins vinte anos depois da sua morte"). 
D'ONOFRIO, S. et al. Conto brasileiro, quatro leituras: Machado de Assis, Graciliano Ramos, Guimarães Rosa, Osman Lins. Petrópolis: Vozes, 1979.

FERREIRA, E. "A dama e o unicórnio: Literatura e imagem na obra de Osman Lins". In: Diário Oficial. Estado de Pernambuco, Recife, ano XII, maio/junho de 1998, p. 27-9 (Suplemento Cultural, "O mundo das palavras, as palavras do mundo, ensaios e depoimentos revisitam cosmos e linguagem de Osman Lins vinte anos depois da sua morte").

. Cabeças compostas: A personagem feminina na narrativa de Osman Lins. Rio de Janeiro: [s.n.], 2000.

GAMA, R. "Metáfora estrutural de Osman Lins alça novo vôo". Entrelivros, maio de 2005.

HELIO, M. "Os caminhos e labirintos do invencível Osman Lins". In: Diário Oficial. Estado de Pernambuco, Recife, ano XII, maio/junho de 1998, p. 2 (Suplemento Cultural, "O mundo das palavras, as palavras do mundo, ensaios e depoimentos revisitam cosmos e linguagem de Osman Lins vinte anos depois da sua morte").

HOLANDA, L. "Uma abreviatura do mundo". In: Diário Oficial. Estado de Pernambuco, Recife, ano XII, maio/junho de 1998, p. 18 (Suplemento Cultural, "O mundo das palavras, as palavras do mundo, ensaios e depoimentos revisitam cosmos e linguagem de Osman Lins vinte anos depois da sua morte").

IGEL, R. Osman Lins: Uma biografia literária. São Paulo/Brasília: T. Um Queiroz/INL, 1988.

LADEIRA, J. de G. "Um autor adiante de seu tempo". In: Diário Oficial. Estado de Pernambuco, Recife, ano XII, maio/junho de 1998, p. 8 (Suplemento Cultural, "O mundo das palavras, as palavras do mundo, ensaios e depoimentos revisitam cosmos e linguagem de Osman Lins vinte anos depois da sua morte").

LEMOS, G. "Meu amigo Osman Lins". In: Diário Oficial. Estado de Pernambuco, Recife, ano XII, maio/junho de 1998, p. 9-10 (Suplemento Cultural, "O mundo das palavras, as palavras do mundo, ensaios e depoimentos revisitam cosmos e linguagem de Osman Lins vinte anos depois da sua morte").

LINS, L. "Quando o escritor é pai". In: Diário Oficial. Estado de Pernambuco, Recife, ano XII, maio/junho de 1998, p. 6-7 (Suplemento Cultural, "O mundo das palavras, as palavras do mundo, ensaios e depoimentos revisitam cosmos e linguagem de Osman Lins vinte anos depois da sua morte"). 
. "Fazia questão de que não perdêssemos o sonho". In: Diário Oficial. Estado de Pernambuco, Recife, ano XII, maio/junho de 1998, p. 7 (Suplemento Cultural, "O mundo das palavras, as palavras do mundo, ensaios e depoimentos revisitam cosmos e linguagem de Osman Lins vinte anos depois da sua morte").

MONTEIRO, L. C. “A crítica de cultura que fez Osman Lins". In: Diário Oficial. Estado de Pernambuco, Recife, ano XII, maio/junho de 1998, p. 21 (Suplemento Cultural, "O mundo das palavras, as palavras do mundo, ensaios e depoimentos revisitam cosmos e linguagem de Osman Lins vinte anos depois da sua morte").

MOISÉS, M. A literatura brasileira através dos textos. São Paulo: Cultrix, 1974.

MOURA, I. Osman Lins: O matemático da prosa. Recife: Fundação de Cultura Cidade do Recife, 2003 (Col. Malungo, 8).

NITRINI, S. (org.). Poéticas em confronto: Nove, novena e o novo romance. São Paulo/Brasília: Hucitec/INL, 1987.

. "Osman Lins transforma em cosmos o caos das palavras". O Estado de S. Paulo, São Paulo, 12/3/1995.

. "Viagem real, viagens literárias: Osman Lins na França e o Marinheiro de primeira viagem". In: Diário Oficial. Estado de Pernambuco, Recife, ano XII, maio/junho de 1998a, p. 22-3 (Suplemento Cultural, "O mundo das palavras, as palavras do mundo, ensaios e depoimentos revisitam cosmos e linguagem de Osman Lins vinte anos depois da sua morte").

. "Viagens reais, viagens literárias: escritores brasileiros na França". Literatura e Sociedade, São Paulo, no 3, 1998b, p. 51-61.

. Aquém e além mar: Relações culturais Brasil e França. São Paulo: Hucitec, 2000, 230

p.

. "Da intermediação cultural ao diálogo cifrado (Osman Lins e Michel Butor)". Comunicação ao VIII Congresso ("Mediações") da Abralic, s/d.

. "Poéticas de tensões". In: Cult - Revista Brasileira de Literatura, São Paulo, no 48, ano V, p. 46-9.

. "O tempo na arte, a arte no tempo (Uma leitura de Marinheiro de primeira viagem)". Documento gentilmente obtido com a autora, ainda não publicado ao tempo da consulta. 
PAES, J. P. "Um olhar de azul muito intenso". In: Diário Oficial. Estado de Pernambuco, Recife, ano XII, maio/junho de 1998, p. 13 (Suplemento Cultural, "O mundo das palavras, as palavras do mundo, ensaios e depoimentos revisitam cosmos e linguagem de Osman Lins vinte anos depois da sua morte").

PERRONE-MOISÉS, L. Inútil poesia e outros ensaios breves. São Paulo: Companhia das Letras, 2000.

SOARES, M. B. "No arquivo do artesão". In: Cult - Revista Brasileira de Literatura, São Paulo, no 48, ano V, p. 62-3.

SOUZA, H. A. de A. "O cárcere Brasil". In: Cult - Revista Brasileira de Literatura, São Paulo, $n^{\circ}$ 48, p. 53-5.

SOUZA, H. A. de A. (org.). O sopro na argila. São Paulo: Nankin, 2004.

\section{Geral:}

ADORNO, T. W. \& HORKHEIMER, M. Dialética do Esclarecimento. Tradução de G. A. de Almeida. 2a ed. Rio de Janeiro: Jorge Zahar, 1986.

ARISTÓTELES. Poética. Tradução de E. de Souza. São Paulo: Ars Poética, 1992 [Ed. gregoportuguês].

AUERBACH, E. Mimesis. São Paulo: Perspectiva, 1971.

BAKHTIN, M. Problemas da poética de Dostoievski. Tradução de P. Bezerra. Rio de Janeiro: Forense Universitária, 1981.

- Questões de literatura e de estética: A teoria do romance. Dir. de E. Samain. Trad. de A. F. Bernardini et al. (do russo). $5^{\text {a }}$ ed. São Paulo: Hucitec/Annablume, 2002.

BARBOSA, J. A. A metáfora crítica. São Paulo: Perspectiva, 1974. . Opus 60: Ensaios de crítica. São Paulo: Duas Cidades, 1980. . A leitura do intervalo: Ensaios de crítica. São Paulo: Iluminuras, 1990. 
BARROS, D. L. P. de \& FIORIN, J. L. (orgs.). Dialogismo, polifonia, intertextualidade: Em torno de Bakhtin, Mikhail. São Paulo, Edusp, 1994 (Ensaios de Cultura, 7).

BARTHES, R. O prazer do texto. São Paulo: Perspectiva, 2004, $4^{\text {a }}$ ed.

. O grau zero da escritura. Tradução de A. Arnichand \& Á. Lorencini. São Paulo: Cultrix, s/d.

BENJAMIN, W. Obras escolhidas. Vol. 1: Magia e técnica, arte e politica. $2^{\text {a }}$ ed. São Paulo: Brasiliense, 1986.

BERNARDINI, A. F. "Formalismo russo, uma revisitação". Literatura e Sociedade, São Paulo, no 5, 2000, p. 30-42.

BOUTOT, A. Introdução à filosofia de Heidegger. Tradução de F. Gonçalves. Mira-Sintra: Europa-América, [1993] (Série Universitária, 66).

BRANDÃO, J. de S. Mitologia grega. Petrópolis: Vozes, 2000 (Vol. 1), 2001 (Vol. 2), 2001 (Vol. 3). . Dicionário mítico-etimológico. Petrópolis: Vozes, 2000, 2 vols.

BRANDÃO, R. de O. A tradição sempre nova. São Paulo: Ática, 1976, 98 p. (Col. Ensaios, 21).

BRICOUT, B. (org.). Olhar de Orfeu: Os mitos literários do Ocidente. Tradução de L. O. Benoit. São Paulo: Companhia das Letras, 2003.

BRUNEL, P. (org.). Dicionário de mitos literários. Tradução de C. Sussekind, J. Laclette, M. T. R. Costa, V. Whately. Rio de Janeiro: José Olympio/UnB,. s/d.

BUTOR, M. La modification. Paris: Les Éditions de Minuit, 1957. Ventos)

A modificação. Tradução de O. Mendes. Belo Horizonte: Itatiaia, 1958 (Col. Rosa dos 
CANDIDO, A. Literatura e sociedade: Estudos de teoria e história literária. São Paulo: Companhia Editora Nacional, 1985, $7^{\mathrm{a}}$ ed. (Biblioteca Universitária, Série 2, Ciências Sociais, 49).

. Educação pela noite e outros ensaios. $3^{\mathrm{a}}$ ed. São Paulo: Ática, 2000 (Série Temas,

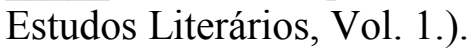

. Tese e antítese: Ensaios. $4^{\mathrm{a}}$ ed. São Paulo: T. A. Queiroz, 2000 (Biblioteca de Letras e Ciências Humanas, Série 2a , Textos, 8).

CARDOSO, S. et al. (Org.). Os sentidos da paixão. São Paulo: Companhia das Letras, 1987.

CASSIRER, E. Linguagem e mito. Tradução de J. Guinsburg \& M. Schnaiderman. $4^{\text {a }}$ ed. São Paulo: Perspectiva, 2000 (Col. Debates, 50).

. Ensaio sobre o homem: Introdução a uma filosofia da cultura humana. Tradução de T. R. Bueno. São Paulo: Martins Fontes, 2005 (Col. Tópicos).

CHAUI, M. Introdução à história da filosofia: dos pré-socráticos a Aristóteles. São Paulo: Brasiliense, v. I, 2003.

CLÚVER, C. "Estudos inter-artes”. Literatura e Sociedade, São Paulo, n 2, 1997.

COHEN, J. A plenitude da linguagem: Teoria da poeticidade. Coimbra: Livraria Almedina, 1987, $262 \mathrm{p}$.

COUTO, R. R. Chão de França. São Paulo: Companhia Editora Nacional, 1935 (Col. Viagens, VII).

CULLER, J. Teoria literária: Uma introdução. São Paulo: Beca, 1999.

DERRIDA, J. A farmácia de Platão. Tradução de R. da Costa. São Paulo: Iluminuras, 1991.

DORÉ, P. G. Dom Quixote, Miguel de Cervantes. Organização de G. Juniro. São Paulo: Opera Graphica, s/d.

EAGLETON, T. Teoria da literatura: Uma introdução. São Paulo: Martins Fontes, 2003. 
ECO, U. Semiótica e filosofia da linguagem. São Paulo: Ática, 1991. . Os limites da interpretação. $2^{\mathrm{a}}$ ed. São Paulo: Perspectiva, 2004.

ELIADE, M. Mito e realidade. $6^{\text {a }}$ ed. São Paulo: Perspectiva, 2004.

FOUCAULT, M. Nietzsche, Freud e Marx: Theatrum philosoficum. Porto: Rés, 1975, 69 p.

FRYE, N. Anatomia da crítica. Tradução de P. E. da S. Ramos. São Paulo: Cultrix, 1973.

GHYKA, M. C. Esthétique des proportions dans la nature et dans les arts. $5^{\mathrm{a}}$ ed. Paris: Gallimard, s/d.

. Sortilèges $d u$ verbe. Prefácio de L.-P. Fargue. $8^{\mathrm{a}}$ ed. Paris: Gallimard, s/d..

GROSSMAN, L. Dostoiévski artista. Tradução de B. Schnaiderman. Rio de Janeiro: Civilização Brasileira, 1967.

HEIDEGGER, M. Conferências e escritos filosóficos. Tradução e notas de E. Stein. São Paulo: Abril Cultural, 1973 (Col. Os Pensadores, XLV).

. Hölderlin y la esencia de la poesía. Barcelona: Anthropos, 1989.

. Ser e tempo, Parte I. 12ª ed. Petrópolis: Vozes, 2002.

. Ser e tempo, Parte II. $11^{\mathrm{a}}$ ed. Petrópolis: Vozes, 2004.

. A caminho da linguagem. Tradução de M. de S. C. Schuback. Petrópolis:Vozes, 2003.

. A essência do fundamento. Lisboa: Edições 70, s/d.

. A origem da obra de arte. Lisboa: Edições 70 [1990, data de impressão]. 
ISER, W. $O$ ato da leitura: Uma teoria do efeito estético. Tradução de J. Kretschmer. São Paulo: Ed. 34, 1996 (Vol. 1), 1999 (Vol. 2).

JAKOBSON, R. Lingüística e comunicação. São Paulo: Cultrix, 1974.

JAUSS, H. R. Pour une esthétique de la réception. Paris: Gallimard, 1991.

. A literatura como provocação: História da literatura como provocação literária. Prefácio de T. Cruz. $2^{a}$ ed. Lisboa: Veja/Passagens, s/d.

KAISER, G. R. Introdução à literatura comparada. Lisboa: Fundação Calouste Gulbenkian, 1989.

KRISTEVA, J. Recherches pour une sémanalyse. Paris: Seuil, 1969. . Introdução à semanálise. Tradução de L. H. F. Ferraz. São Paulo: Perspectiva, 1974

transformacional. Tradução de M. Ruas. Lisboa: Horizonte, 1984.

LACAMBRE, G. Gustave Moreau, maître sorcier. Paris: Gallimard/Réunion des Musées Nationaux, 2003 (Découvertes).

LIMA, J. de. Invenção de Orfeu. Biografia, intr. e notas de M. C. Proença. Rio de Janeiro: Ediouro, s/d.

LIMA, L. C. Vida e mimesis. Rio de Janeiro: Ed 34, 1995. . Mímesis: Desafio ao pensamento. Rio de Janeiro: Civilização Brasileira, 2000.

LIMA, L. C. (ed.). A literatura e o leitor: Textos de estética da recepção. Sel., coord. e trad. de L. C. Lima. $2^{\mathrm{a}}$ ed. Rio de Janeiro: Paz e Terra, 2002.

LYRA, P. "Para um conceito de crítica". Tempo Brasileiro, Rio de Janeiro, $\mathrm{n}^{\mathrm{o}}$ 60, janeiro/março de 1980, p. 98-104. 
MATOS, O. "Melancolia de Ulisses: A dialética do iluminismo e o canto das sereias". In: CARDOSO, S. et al. Os sentidos da paixão. São Paulo: Companhia da Letras, 1999.

MIELIETINSKI, E. M. A poética do mito. Tradução de P. Bezerra. Rio de Janeiro: Forense Universitária, 1987.

MILNER, M. On est prié de fermer les yeux. Paris: Gallimard, 1991.

MORAIS, R. de (org.). As razões do mito. Campinas: Papirus, 1988.

NASCIMENTO, E. Derrida e a literatura: "Notas" de literatura e filosofia nos textos de desconstrução. Niterói: EdUFF, 1999.

NITRINI, S. "Da sedução à saudade literária: Literatura de viagem na Belle Époque". Literatura e Sociedade, São Paulo, nº 6, 2001-2, p. 224-38.

NOVAES, A. (org.). O olhar. São Paulo: Companhia das Letras, 1988.

NUNES, B. Texto, crítica, escritura. São Paulo: Ática, 1978.

. Passagem para o poético: Filosofia e poesia em Heidegger. $2^{\mathrm{a}}$ ed. São Paulo: Ática, 1992, 304 p. (Col. Ensaios, 122).

67).

. Crivo de papel. São Paulo: Ática, 1998, $2^{\mathrm{a}}$ ed. (Série Temas, Filosofia e Literatura, . Hermenêutica e poesia: O pensamento poético. Organização de M. J. Campos. Belo Horizonte: Ed. UFMG, 1999.

. "Meu caminho na crítica". Estudos Avançados, São Paulo, Vol.19, n 55, set./dez. 2005, p. 289-305.

PAES, J. P. Transleituras. São Paulo: Ática, 1995.

PAZ, O. O arco e a lira. Tradução de O. Savary. Rio de Janeiro: Nova Fronteira, 1982. 
. Signos em rotação. Tradução de S. U. Leite; Organização e versão de C. Lafer \& H. de Campos. $3^{\text {a }}$ ed. São Paulo: Perspectiva, 2003, $3^{\text {a }}$ ed.

PERRONE-MOISÉS, L. Texto, crítica, escritura. São Paulo: Ática, 1978.

PIRES, M. L. G. Para uma leitura intertextual de "Exercícios espirituais" do Padre Manuel Bernardes. Lisboa: Instituto Nacional de Investigação Científica, Centro de Literaturas de Expressão Portuguesa da Universidade de Lisboa, 1980

PlATÃO. Diálogos. Parmênides e Filebo. Vol. VIII. Trad. de C. A. Nunes. Belém: Universidade Federal do Pará, 1974. $\overline{\text { Ensaios). }}$

. Fedro. Tradução e notas de P. Gomes. Lisboa: Guimarães, 1986 (Col. Filosofia \& . A República. Introdução, tradução e notas de M. H. da R. Pereira. $7^{\mathrm{a}}$ ed. Lisboa:

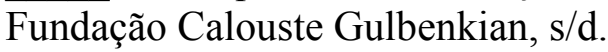

PROUST, M. Em busca do tempo perdido. Tradução de F. Py, $3^{\mathrm{a}}$ ed. Rio de Janeiro: Ediouro, 2004, vols. 1, 2 e 3.

RICEUR, P. Interpretação e ideologias. Rio de Janeiro: Francisco Alves, 1990.

. A metáfora viva. Porto: Rés, s/d.

. Teoria da interpretação. Lisboa: Editora 70, s/d.

RENOIR, P. A. Gênios da pintura. São Paulo: Abril Cultural, s/d.

SAMOYAULT, T. L’intertextualité - Mémoire de la littérature. Paris: Nathan, 2001.

SARTRE, J.-P. Que é a literatura. 2a ed. São Paulo: Ática, 1993.

. Littérature comparée. Paris: Puf, 1997.

SOREL, R. Les cosmogonies grecques. Paris: Presses Universitaires de France [data de impressão, maio de 1994]. 
. Ophée et l'orphisme. Paris: Presses Universitaires de France (Col. Que sais-je?) [data de impressão, novembro de 1995]

TADIÉ, J.-Y. A crítica literária no século XX. Rio de Janeiro: Bertrand Brasil, 1992.

TODOROV, T. As estruturas narrativas. São Paulo: Perspectiva, 1979.

WERLE, M. A. Poesia e pensamento em Hölderlin e Heidegger. São Paulo: Editora Unesp, 2005. 
ANEXOS 


\section{Anexo 1}

Cartas de Osman Lins relacionadas com sua primeira viagem à Europa 
1. Carta a M. François Grégoire. Informação encontrada no arquivo do autor, pesquisado no IEB-USP. Caixa 1: Grupo Formação. Evento: Inscrição para bolsa de estudos da Aliança Francesa. Notação: OL/FORMAÇÃO/CX 1.

Recife, 31 de janeiro de 1960

Prezado Senhor:

Acuso o recebimento da sua carta $63 / \mathrm{FG} / \mathrm{GD}$, de 14 do corrente, pela qual fui informado, com surpresa, que é de praxe não ser feita comunicação alguma aos candidatos cuja bolsa não foi obtida. Nada sabia a respeito. Esperava, mesmo, o contrário, pois assim me prometia M. Lucien Pouessel, em carta mimeografada ref. 951 LP/MP, de 10-7-1959: "J'espère vous faire réponse de Paris avant la fin du mois de Juillet, et je souhaite qu'elle vous soit favorable". É claro que a carta prometia uma informação, qualquer que fosse a resposta da Direction Generale des Affaires Culturelles et Techniques.

Quanto ao motivo de meu dossiê, assim como dez outros, haver chegado a Paris "après le $1^{\text {er }}$ Juillet 1959, c'est-à-dire après la date de clôture des candidatures", motivo que o senhor declara ignorar, é bem simples: meu dossiê deve ter saído dessa Embaixada "après le $1^{\text {er }}$ Juillet", pois ainda a 18 de junho, carta 749 LP/MP, Me. Lucien Pouessel me escrevia, pedindo-me preencher e remeter-lhe "deus formulaires etat modèle $24 \mathrm{U}$, un depliant et une copie du diplome d'études secondaires". A 26 de junho, carta 854 LP/MP comunicava-me o recebimento dos referidos documentos. Ainda que os remetesse, nesse mesmo dia, para a França, dificilmente chegariam eles antes de $1^{\circ}$ de julho. E isto, parece, não foi feito, pois, a carta mimeografada a que me referi acima e que comunica o envio do dossiê, é datada de $1^{\circ}$ de julho.

Esperando, desta vez, ser mais afortunado em minha tentativa, envio, juntamente com um breve plano de estudos, o formulário que me foi enviado por V. S. Peço informar-me se o meu dossiê do ano passado é válido para a nova candidatura. Em caso afirmativo, queira informar-me, pelo que muito lhe agradecerei, se devo acrescentar ao mesmo uma cópia da minha vida escolar e um certificado de conclusão de Curso de Dramaturgia, no qual obtive excelentes notas, o ano findo, na Escola de Belas Artes da Universidade do Recife. Se tais documentos são úteis à minha candidatura, enviá-los-ei, pois já os tenho em meu poder. 
Atenciosamente, apresento a V.S. minhas Cordiais Saudações
a.) Osman Lins

M. François Grégoire

L'Attaché Culturel,

près l'Ambassade de France au Brèsil

Rio de Janeiro, DF 
2. Carta a Paulo E. de Berrêdo Carneiro. Informação encontrada no arquivo do autor, pesquisado no IEB-USP. Caixa 1: Grupo Formação. Evento: Inscrição para bolsa de estudos da Aliança Francesa. Notação: OL/FORMAÇÃO/CX 1.

Recife, 5 de fevereiro de 1960

Prezado Senhor:

Acuso o recebimento de sua carta $\mathrm{n}^{\circ}$ 5, de 14 de janeiro p.passado. E vejo-me forçado a responde-la pormenorizadamente, de vez que foram inexatas ou imprecisas as informações prestadas ao Serviço Diplomático do Brasil, sobre a carta por mim enviada ao Sr. Ministro da Educação da França. Na referida carta, eu não manifestava propriamente o desejo de obter uma bolsa de estudos na capital francesa; antes, apelava para o Sr. André Malraux, em virtude de ter sido informado (informação esta recebida de fontes extra-oficiais) de que a bolsa pleiteada por mim, com as melhores recomendações - Alceu Amoroso Lima, Gilberto Freyre e Aníbal Fernandes entre elas -, não fora concedida por motivo que a sua carta me vem confirmar: estar, a Direção Geral dos Assuntos Técnicos e Culturais da França, concedendo apenas bolsas de caráter técnico. E permitia-me dizer, creio que com razão, ao autor de La Condition Humaine:

“Je ne cherche evidemment pas à nier la valeur, de la technique, mais j'avoue que um espoirs étaient fondés sue l'dée de la tradition d'umanisme de votre pays et de um continuité, récemment confirmée par ce fait: le Président Charles De Gaulle a choisi comme Ministre de l'ducation um intelectuel, au courant, plus qu'ucun autre, des problèmes des intellectuels et de leur importance dans notre civilization.

"En fait, on ne saurait amoindrir l'importance de la litérature devant la technique, si celle-ci n'est rien en soi-même et si la vider d'un sens equivaut à éliminer son utilité. Ne fautil pas, en même temps qu'on met en valeur, des spécialistes en eléctronique, offrir aussi des facilités aux écrivains, ceux qui, incapables de manier un compteur Geiger, sont néanmoins les seuls capables d'éveiller dans l'esprit de leurs semblables, au moyen d'articles et de livres, les idées par exemple de la noblesse de l'homme, du respect mutuel ou même, tout simplement, de l'existence humaine, comme des valeurs authentiques et non des mythes? Cela, je le crois, contribuirait à maintenir chez les hommes une atmosphère spirittuelle qui donnerait à la technique une direction morale - son destin et sa raison d'être." 
Acreditei necessária a longa transcrição, para deixar bem claro, perante V. S., o tom da minha carta. Eu me dirigira, com as recomendações a que acima aludi, ao Adido Cultural da Embaixada da França no Rio de Janeiro, havendo o meu dossiê seguido os seus trâmites, até ser julgado por um organismo que, atualmente, como já vimos, só concede bolsas de caráter técnico. (O atual Adido Cultural viria a afirmar-me depois, em carta recente, que o meu dossiê, por motivos que ele ignorava, havia chegado a Paris após a data marcada para o fechamento das inscrições.)

Ora, como todo dossiê entregue na Embaixada Francesa, se aprovado no Brasil, será fatalmente enviado à Direção Geral dos Assuntos Técnicos e Culturais da França, torna-se meio kafkiano o conselho de V. S., tão gentilmente, houve por bem enviar-me: sou reenviado ao mesmo ponto de onde parti, sabendo agora que prosseguir será inútil, pois me cortarão as pretensões no ponto de chegada...

Quanto ao segundo parágrafo da sua carta, segundo o qual a UNESCO só concede bolsas a professores e estudantes universitários, quero declarar, embora não houvesse, direta ou indiretamente, pleiteado qualquer bolsa junto a essa egrégia instituição, que estudante universitário eu o era, até o ano findo, quando concluí um Curso de Dramaturgia, na Escola de Belas Artes, da Universidade do Recife. Não mais o sendo, fecha-se, suponho, a última oportunidade que me restava de um contato, ainda não esgotada a minha juventude, com a civilização européia, contato que seria indispensável, creio-o, à minha formação intelectual. (Tenho dois livros publicados, ambos pela Livraria José Olympio, um deles distinguido com o Prêmio Coelho Neto, da Academia Brasileira de Letras. E colaboro em jornais do Recife e do sul do país.) Assim sendo, recolho as minhas velas, meio abertas para viagens que decerto não farei e resigno-me a continuar aportado neste nosso Recife, entre as carteiras do Banco do Brasil, a cujos quadros pertenço. E já que, para mim, homem sem habilitações técnicas num mundo que promete transformar-se num gigantesco reator, as coisas se tornam cada vez mais difíceis, arrisco, mansamente, uma pergunta: "Não encontraria V. S. motivos para requisitarme, por uns seis ou oito meses, como funcionário junto a essa (para mim quase mitológica) Delegação Permanente do Brasil junto à UNESCO?” Confesso que seria, este, um convite que eu haveria de receber sem constrangimento algum.

Sem mais, e pedindo a V. S. queira relevar a quase irreverência das linhas precedentes, envio-lhe os meus agradecimentos pelo tom profundamente atencioso de sua carta e apresento-lhe os protestos da admiração mais viva. 
Atenciosamente,

a.) Osman da Costa Lins

$\mathrm{Ilm}^{\mathrm{o}} \mathrm{Sr}$.

Paulo E. de Berrêdo Carneiro 
3. Carta de Osman Lins a Gilberto Freyre. Carta de Osman Lins a Gilberto Freyre, quando de sua primeira viagem à Europa

Paris, 31 de março de 1961

Meu caro Gilberto Freyre:

Creio que já sabe que, no sábado e no domingo que antecederam a minha partida, fui à sua casa, em Boa Viagem, e não tive oportunidade de falar-lhe.

Desejo que a sua saúde continue firme. Para o bem de todos e felicidade geral do país.

Aqui estou, neste velho continente, vendo e aprendendo muitas coisas. Sobretudo uma: é para o nosso país e para a nossa época que devemos escrever. Eu teria talvez umas certas veleidades longínquas de vir a ser conhecido no estrangeiro. Hoje, tal idéia me parece completamente superada. Quero, aliás, escrever um artigo sobre isto. Transcender o seu país e a sua época, isto pode vir, mas é acidental, não importa para a obra do escritor. Sinto-me, mais do que nunca, apegado ao meu país. E isto, é bem verdade, ao mesmo tempo que sinto, no estrangeiro, um ser profundamente semelhante a nós, com as mesmas preocupações, idênticas maneiras de ser e merecendo ser amado por nós. Mas, de uma vez por todas, é com o nosso povo que temos compromisso. Lembro-me de que você me falou, certa vez, de um artigo altamente compreensivo sobre livro seu, creio que de um crítico norte-americano. Sim, isto é possível. Também é possível que o público acorra, durante meses, a uma casa de espetáculos, para aplaudir um autor estrangeiro. Mas se esse autor não for ouvido no seu país, ele falhou.

Isto, concordo, dá à minha visão da literatura uma certa estreiteza. Mas, ao mesmo tempo, dá às minhas forças mais firmeza, como se elas se concentrassem. Sinto-me, agora, com esta plena decisão de uma fidelidade total ao meu país e ao meu tempo, mais livre e mais forte.

Escrevo-lhe estas coisas, não por vaidade, mas porque sinto que elas devem interessarlhe e porque a sua grande obra tem sido, toda ela, construída com um grande amor pelo Brasil. Seu interesse em divulgá-la no estrangeiro sendo, em última análise, conseqüência disto.

Não espero, em virtudes de seus inúmeros trabalhos, resposta sua, quando amigos bem menos ocupados ainda não encontraram tempo de escrever-me. No entanto, aí vai meu endereço: 
Maison de l'Alliance Française

Boulevard Raspail, 101, apto. 409 - Paris, VI.

Fazendo votos pela sua felicidade pessoal e pela de sua família, abraça-o afetuosamente o admirador, o amigo

\section{Osman Lins}


Anexo 2

Entrevistas concedidas por Osman Lins, sobre Marinheiro de primeira viagem 
1. NASCIMENTO, Esdras do. Tribuna da Imprensa, Rio de Janeiro, 26/08/63 (IEBUSP) “O livro, visto pelo autor" ou "As viagens do romancista Osman Lins" (encontram-se as duas titulações)

ORIGENS - "Em fins de janeiro de 61 na madrugada de uma segunda-feira, embarquei para a França, a bordo do 'Manga', como bolsista da 'Alliance Française'. A bolsa era pequena, mas me proporcionava o mais difícil: meios para a travessia. Do que foi a viagem - capitão do navio, companheiros - não falo neste livro. Reservo-os para uma série de novelas sobre viagens que penso escrever algum dia. Restringi o MARINHEIRO aos meses de minha permanência no continente europeu”.

SOLIDÃO - "Hospedei-me, de início (isto fazia parte da bolsa) na 'Maison de l'Alliance Française', no Boulevard Raspail. Não conhecia ninguém. Levava, é certo, algumas cartas de apresentação. Preferi, porém, só entregá-las quando estivesse um pouco mais familiarizado com a cidade, para não aparecer com ares de desamparado, de alguém que não sabe s'un d'ébarasser".

"Conheci, assim, de maneira total, a experiência da solidão em terra estrangeira. Este, parece-me, é um dos aspectos interessantes do livro. Analiso aquela experiência acredito que sem sentimentalismo, sem ostentar a minha solidão".

PARIS, PAÍSES - "Fiz de Paris, essa muitas-cidades, meu QG. Viajava, conhecia outras terras, voltava a Paris. É curioso como pode, uma cidade estranha, tornar-se, em pouco tempo, tão familiar. Aprendi, muito cedo, o prazer de voltar ao meu quarto no Boulevard Raspail e, depois, em Montparnasse. Fui à Bélgica e Holanda. Voltei. Suíça e Itália. Voltei. Londres. Voltei. Espanha. Ainda voltei. Por fim, numa manhã bem semelhante àquela em que deixara o Brasil, disse adeus àquela cidade à qual chegara já no fim do inverno, cuja Primavera me encantara e que agora eu via-a pela última vez, sob uma pesada chuva de verão”.

O LIVRO - "Eu não queria, porém, dar ao meu livro, se o escrevesse, um ar de lamentação. Não queria que ele tivesse por lema o 'Recordar é viver'. E sim este outro: 'Escrever é esquecer'. Queria libertar-me da carga de lembranças, de laços, desfazer-me de tudo, deixar aquela viagem, aquela pausa e seu encantamento, para todo o sempre no passado. Coisa vivida. Coisa abandonada".

“Assim, e também para evitar a incômoda intromissão de mim mesmo ante meus próprios olhos, coloquei a narração da viagem na terceira pessoa. O que me trouxe 
ainda outras vantagens: quebrar meu pudor, permitir-me falar um pouco mais à vontade de coisas muito íntimas e aproximar o gênero viagem do gênero romance." "Tomei outras providências. Eliminei do livro, a priori, a descrição de tudo que o possível leitor, acaso viaje, venha a descobrir. Ou possa ler em manuais de turismo, nas enciclopédias ou em compêndios de Geografia. Meu livro não trata do permanente: é do transitório que se ocupa. Do único. Do que não virá a repetir-se. Não iria cometer a impertinente asneira de dizer como é a Torre Eiffel."

"Há, é certo, descrições de coisas que não mudam, no sentido em que são imutáveis para nós. Referem-se, porém, a coisas dificilmente encontráveis, certo restaurante escondido numa pequena rua de Amsterdam, o quarto de um pequeno hotel em Tours."

VIAJAR ATRAVÉS DOS LIVROS - "Não é meu desejo que o possível leitor de MARINHEIRO DE PRIMEIRA VIAGEM venha a procurá-lo com a ilusão de viajar através de suas páginas. Desejaria que ele abrisse o livro com uma expectativa de outra natureza, a meu ver legítima: a de ler um livro. Pois é isto, afinal, o que pretende ser o meu trabalho: um livro. Uma obra literária”.

"Se ele quisesse ser, antes de tudo, um relato de viagem, eu não teria omitido, ao escrevê-lo, fatos em si mesmo 'importantes' como a visita à cidade de Rouen, tão cheia das presenças de Flaubert e Joana d'Arc. Todavia, no livro, nem sequer menciono Rouen. Isto porque, literariamente, Rouen, por um motivo qualquer, nada me sugeriu. Não me foi possível fazer literatura com Rouen."

"Falo de corridas de touros, de outras festividades públicas, de Veneza, de Córdova e Sorento, de Londres, mas também de gente que apenas entrevi, com quem cruzei numa rua, com quem viajei num trem, desde que, literariamente, fui estimulado."

"Daí, por pretender ser, antes de tudo, literatura, é que o livro obedece a uma construção, a um plano. Se as primeiras impressões se fundem com as últimas, é para dar a impressão de um círculo, de uma fase não inscrita no seguimento normal da minha vida, como a esfera que eu vi, em não sei que quadro abstrato, ao lado de uma curva." 
2. SAVAGET, Edna. "Os deuses nada arriscam", Jornal do Commercio - Recife 29/12/1963.

Osman Lins, convidado a voltar a estas páginas, remete esta entrevista à jornalista Edna Savaget, justamente quando o seu nome está outra vez ligado às vitrines de livros novos com Marinheiro de Primeira Viagem. Seria dispensável apresentar aos leitores deste Suplemento o seu antigo colaborador, que aqui volta para falar de suas atuais preocupações e projetos literários.

\section{(...)}

Como e por que escreveu Marinheiro de Primeira Viagem?

A viagem, a permanência de seis meses na Europa, foi uma experiência marcante. Eu estava cheio de lembranças acumuladas. Elas me impediam de realizar tranquilamente os trabalhos de ficção que antes me impusera. Então, planejei o relato, pus em ordem as recordações. Como disse em entrevista ao Esdras do Nascimento, escrevi para esquecer. E, uma vez que ia fazer o livro, tentei renovar o gênero viagem, evitando de modo sistemático e permanente os lugares comuns, atendo-me em geral ao passageiro, ao que nenhum outro viajante poderá encontrar. Foi útil escrevê-lo. Ao ficcionista é necessário vez por outra, para corrigir certos hábitos da imaginação, um contato assim direto com o que pretende relatar. 
Anexo 3

Algumas críticas sobre Marinheiro de primeira viagem 
1. CAMPOS, Geir. Última Hora, Rio de Janeiro, 09/09/1963. Título incompleto: DE PRIMEIRA VIAGEM - [deve estar faltando a palavra MARINHEIRO, pois é um recorte do jornal] (IEB-USP).

Informação encontrada no arquivo do autor, pesquisado no IEB-USP. Caixa 1: Grupo Literatura. Tema: Marinheiro de primeira viagem. Notação: OL/LIT/MARINHEIRO/CX 1. Pasta 1/07.

Osman Lins, que estreou como romancista em O Visitante (1955) e que depois fez uma bela surpresa com aquela peça Lisbela e o Prisioneiro um dos enredos teatrais mais bonitos que já vi, aparece agora como Marinheiro de primeira viagem, numa espécie de livro de horas da viagem que fez por este e outros continentes. Osman Lins nesse livro fala de gente e de coisas de longe, sempre como um escritor capaz de captar o que há de mais humano aqui e acolá. Trata-se mais de um relatório ou depoimento, mas escrito com arte. 
2. MARINHEIRO de primeira viagem. Correio da Manhã (s/local) 10/09/63 (IEBUSP).

Informação encontrada no arquivo do autor, pesquisado no IEB-USP. Caixa 1: Grupo Literatura. Tema: Marinheiro de primeira viagem. Notação: OL/LIT/MARINHEIRO/CX 1. Pasta 1/08.

\section{Marinheiro de primeira viagem}

Em 1961, convidado pela Aliança Francesa, o romancista Osman Lins viajou para Paris como bolsista, ocasião em que teve oportunidade de visitar também outros países, tais como Bélgica, Holanda, Suíça, Itália, Inglaterra, Espanha e Portugal. Durante sua permanência em todas essas terras, anotou ele, escrupulosamente, servindo-se de seu espírito de observação e do seu talento de ficcionista, o que viu e sentiu mais profundamente: gente do povo, ruas, museus, festas, comidas, paisagens, etc. O resultado foi este livro bem escrito e inteligentemente planejado, que a Editora Civilização Brasileira acaba de publicar, Marinheiro de primeira viagem, cuja leitura, de enorme interesse, recomendo aos apreciadores do gênero. 
3. MASSAUD, Moisés. "Viajar e imaginar", O Estado de S. Paulo, São Paulo, 08/02/64. Suplemento Literário (IEB-USP).

Informação encontrada no arquivo do autor, pesquisado no IEB-USP. Caixa 1: Grupo Literatura. Tema: Marinheiro de primeira viagem. Notação: OL/LIT/MARINHEIRO/CX 1. Pasta 1/10.

Em 1961, Osman Lins publicou “O Fiel e a Pedra", depois de uma lenta elaboração de cinco anos. Embora a crítica não lhe tenha dado a atenção merecida, foi, sem favor nenhum, o mais significativo romance aparecido naquele ano. Agora, decorridos dois anos, publica "Marinheiro de Primeira Viagem" (Rio de Janeiro, Ed. Civilização Brasileira, 1963). No ano em que saiu "O Fiel e a Pedra", uma bolsa de estudos levou-o a Paris e outras cidades francesas. Terminado o estágio, entregou-se a demorada e vibrante peregrinação pela Bélgica, Holanda, Suíça, Itália, Inglaterra, Espanha e Portugal. Do muito que viu e observou, das várias experiências e peripécias vividas, tirou o material que lhe serviu para contar suas andanças de "Marinheiro de Primeira Viagem".

Comecemos pelo título. Não nos iludamos: está muito longe de ser o que parece. Vendo-o de relance temos a impressão de que se trata apenas dum relato de primeira viagem, isto é, de alguém que viaja pela primeira vez. Entretanto na intimidade da obra, percebemos que é e não é ao mesmo tempo primeira viagem. Parafraseando Fernando Pessoa, dir-se-ia que o ser primeira viagem pode não ser obrigatoriamente a primeira. Não raro, muitos viajam repetidas vezes como se fosse a primeira, ou se jamais houvessem abandonado os penates. Ao passo que outros se jogam na aventura do desconhecido como se houvessem viajado a vida inteira, ou se, numa única viagem, realizada com intensidade e sofreguidão, esgotassem todas as emoções que poderiam colher de numerosas e variadas viagens.

Osman Lins, como desde sempre seria de esperar, situa-se entre esses raros. Nele, viajar é o antiturismo por excelência, se considerarmos turismo no sentido em que comumente é tido o deslocamento no espaço para ver coisas e gentes. Não foi um turista, como é a maioria dos que podem viajar, e só enxergam o que lhes aponta o guia bocejante e mecânico dos museus e excursões. Ou, mais esnobes ainda, que vão às compras nos grandes bazares do mundo (Nova York, Paris, Roma, Londres...). E, de passagem, "com tempo marcado para o exercício da admiração pré-fabricada” (p. 37), se lançam freneticamente a tirar fotografias dos mesmos lugares que desde o começo das modas vêm sendo explorados nos cartões postais, como bem observa Osman Lins, num de seus sempre agudos "instantâneos", focalizando os 
turistas, esses seres estranhos que, "de máquinas em punho e óculos escuros”, vão à procura de prazeres exóticos para as entranhas e as glândulas.

Ao contrário do turista, Osman viajou na sua condição de escritor, de romancista. Esquisita e incômoda condição, diga-se de passagem, que não passou despercebida ao funcionário "atencioso", cumpridor de seus deveres, tão cego quanto podem ser os "perfeitos" funcionários de burocratas inúteis - que lhe preparou o passaporte para a liberdade do espírito e dos sentidos. O episódio, conta-o Osman em duas páginas de autêntico e saboroso humor, o seu tanto tirado ao tragicômico:

\section{“- Profissão?}

- Escritor.

- Não pode ser. Não é isto que consta dos documentos do Imposto de Renda.

- Naturalmente. Não se paga Imposto de Renda como jornalista ou escritor.

- Tenho de pôr 'bancário'.

O senhor não trabalha em Banco?

- Trabalho.

- Quer dizer que é escritor-amador.

- Existe rádio-amador, mas não escritor-amador. Ou se é escritor, ou não se é.

- Mas se o senhor trabalha em Banco, tenho de pôr 'bancário'.

- Não é como bancário, e sim como escritor, que viajo (...)

- Pois eu só posso pôr "escritor”, se o senhor provar que é escritor.

- Trago-lhe meus livros.

- Ah, não servem.

- Como é que não servem?

- É preciso trazer um documento, assinado por duas pessoas, atestando que o senhor é escritor.

- Selado?

- Perfeitamente. Com firma reconhecida.

- Então os livros não servem.

- Claro que não, meu senhor. Livro não é documento” (pág. 43).

Mas foi como escritor que acabou conhecendo o Velho Mundo, e é nessa "esdrúxula" e "mirífica" condição, ao ver daquele funcionário "exemplar" que nos conta suas impressões de viagem: a narrativa, em forma de diário não inteiramente escrito ao vivo dos 
acontecimentos, é composta de fragmentos, de "flashes" ou "fotografias" encadeados apenas pela memória. Formalmente, desobedecem a qualquer esquema coordenador atento à ordem do relógio ou dos dias. Só o itinerário percorrido confere uma ordem, e, ainda assim, ocasional, às reminiscências. Se fossem organizadas doutro modo, o resultado seria praticamente o mesmo, porquanto o conteúdo dos episódios tem valor em si, independente do como forem eles ordenados.

O escritor refere-se a si, enquanto viajante, na terceira pessoa, e sempre que aparece na primeira pessoa, é como se fosse o próprio viajante (isto é, o ficcionista) que toma a palavra. A composição do relato segue um esquema de romance. Por outras palavras: quando tudo começa, encontramos o narrador em Lisboa, na etapa final de suas peregrinações, e já disposto a repassá-las na memória, e a fixá-la no papel. Daí por diante, o filme vai desenrolarse aos nossos olhos, principiando da metade para o fim. E, aqui e ali, por associacionismo espontâneo, subordinado ao próprio fluir dos acontecimentos ou das imagens que eles deixaram na retina do narrador, este nos conta passagens anteriores à sua chegada à Europa ou ligadas à sua terra natal.

Dessa forma, a primeira parte da viagem aparece apenas como vários quadros em desordem, visto nascerem ao sabor das lembranças. Tem-se a impressão indelével de que tudo se passa à nossa frente como um romance. Não só a técnica, mas também e sobretudo o modo como Osman viu a Europa, autorizam o leitor a erguer tal juízo. É que Osman sentiu a "velha cortesã" como poucos sentiram, justamente porque convocou a imaginação poderosa de ficcionista superior para o festim da sensibilidade na sondagem do desconhecido. E, com isso, penetrou nos escaninhos duma antiga civilização, que escapam via de regra ao olhar ligeiro, auto-suficiente e afetado, dos turistas e "blasés" dos trópicos, apenas à procura de sensações fortes e deslumbramentos provincianos na Europa lendária e fatigada. 
4. MELLO, Virgínius da Gama e. Jornal do Commercio, Recife, 22/03/64 (IEB-USP)

"Marinheiro de primeira viagem".

Informação encontrada no arquivo do autor, pesquisado no IEB-USP. Caixa 1: Grupo Literatura. Tema: Marinheiro de primeira viagem. Notação: OL/LIT/MARINHEIRO/CX 1. Pasta 1/09.

- Livros de viagem, raros escapam do descritivo, da fixação de coisas, pessoas, lugares, sempre tomados em perspectiva, em posição de que estão sendo vistos. Indisfarçável em livros assim certa pose, digamos, até dos monumentos, como se tudo de fora estivesse em atitude consciente, imponente, para deslumbramento do estrangeiro. Muitos, é certo, não se exteriorizam quando transpostos ao papel impresso apenas por isto e se acrescentam então duma vivência cultural, do que está por trás e se foi construindo ao longo dos tempos e dos variados e peculiares espaços culturais. São estes os livros de viagem mais inteligentes, onde não nos chega somente a visão comum duma câmera mas aquela visão só possível em virtude duma longa experiência cultural, duma maneira de viver em profundidade e que se confunde com a própria história da civilização, livros de pessoas cultas, portanto, que despojam do simples ato de ver, de certa forma, a pura aparência, ficando em destaque o que ela representa.

Raro, raríssimo, o livro de viagem que se mostra com esta singularidade do trabalho de Osman Lins - "Marinheiro de Primeira Viagem". Aqui temos o que se poderia chamar "viajar para dentro". Claro que Osman Lins, realmente, viajou e sua travessia não foi dentro das quatro paredes de um quarto, a exemplo de De Maistre. Mas é inegável que viajou dentro de si mesmo e a forma adotada para o livro, originalíssima, em grande parte na terceira pessoa, foi talvez uma imposição de sua maneira de viajar à Europa. Viu muito, é exato, mas viu distante, solitário, sempre se vendo como "ambulante fugaz", tal como se descreve na terceira pessoa a presença, os atos daquele viajante, que é ele próprio. Além disso viu muito, mas viu de relance. Não é o problema do tempo em si, mas dum tempo sempre pressionado pela consciência no próximo acabar da não permanência daquelas coisas vistas - tempo de cinema, digamos. Quase em nenhum momento, visualizando tantos lugares e cidades, praticamente existiu para ele a aventura do reencontro - toda a Europa desfiou, é o termo, diante dele, mas desfilou apenas, sem lhe deixar marca mais profunda que a do cartão postal. Nem sem razão que no aeroporto de Lisboa se desfaça deles, entregando-as a um garoto, aqueles cartões, notas, endereços, que juntara talvez cuidadosamente em suas andanças como num enorme esforço de fixação, uma provocação inútil de permanência. E suas visões de Europa, principalmente o que destaca como "momentos" apresentam certa melancolia, a vida sempre 
passando ao largo, daquela vida dos outros, da qual não participa e que apenas observa. Até mesmo as pessoas com quem fala, com quem convive, os Márcio, por exemplo, todas lhe dão a insegurança do passageiro, do que não ficará. $O$ episódio do trem, onde todos os participantes de um compartimento se enganam e entregam na estação a maleta que julgavam esquecida e que, entretanto, pertencia a um deles que continuava a viagem, é bem significativo e quase simbólico da posição espiritual do viajante Osman Lins que não teve a sensação do "já visto", do reencontro, mas da melancolia de ver sem existir, sem ser para aquele povo, aquela paisagem.

A existência do ficcionista em Osman Lins explicará possivelmente essa atitude e essa contemplação européia que são suas visões de "marinheiro de primeira viagem". Seleção de ficcionista, sem dúvida, é a dos quadros - notas, que reúne ao longo do volume. E todos do ponto de vista da terceira pessoa, narrativa de romance clássico, embora algumas vezes já se encaminhando para o "novo romance" do qual aliás faz uma bela tentativa na descrição de seu encontro com Alain Robbe Grillet, buscando melancòlicamente uma visão de si mesmo com entrosamento na paisagem ou no panorama urbano. Como se revivesse observando-se nos passos referidos, nos lugares visitados, nas pessoas encontradas. Afirmando uma vitória pessoal do espírito, que é também um renascimento, pois que o homem novo reaparecido do outro lado do Atlântico está diante da vida com uma consciência de destino. Uma atitude de um humanismo que lembra curiosamente a dos escritores e viajantes europeus após os princípios de colonização da América.

A seleção dos - notas, realizada por um ficcionista, ainda se demonstra porque esse livro apresenta indiscutível feição de "diário", no sentido menos de anotação a cada dia (coisa que não existe nesse trabalho) mas de visão progressiva da atitude de um viajante evoluindo paulatinamente em densidade interior à medida que desfilam coisas, lugares, pessoas. A viagem não será tanto a relação de coisas vistas e sentidas, estará mais na incorporação sentimental, psíquica, que está realizando em desenvolvimento de personalidade. Daí a imagem de vida que se renova, o símbolo (R) Eurídice apresentando-se para comunicar o retorno definitivo ao passado. Até que ponto a contemplação européia e o conseqüente enriquecimento de Osman Lins terão modificado ou não o que poderíamos chamar, lembrando Flaubert, sua “educação sentimental”, não se pode calcular nem mesmo seja esta a interpretação verdadeira.

Há indícios curiosos da permanência de Osman Lins como homem anterior, uma sugestão de que o seu contemplativismo europeu apenas reforçou o que já havia adquirido, as dotações íntimas que o levaram à ficção. Um ficionismo - esclarece-se agora melhor com este 
"Marinheiro de Primeira Viagem" - resultante não apenas da escolha de um gênero, de uma vocação, mas duma forma de exprimir-se em busca dum conhecimento da vida, que é mais deles que de suas personagens. Eis aí um ficcionista que - parece - estará sempre fadado à renovação, a cada livro apresentando avanços, senão de forma e nível artístico, pelo menos e, seguramente, de sua própria visão do mundo e das pessoas. Um ficcionista que, por destino, estará sempre em permanente ascenção interior.

As observações pessoais que ele realiza na Europa, o que nos informa dela, seus contatos com lugares, coisas, pessoas, principalmente suas entrevistas com grandes nomes de literatura e teatro, são das mais inteligentes, curiosas, apresentadas no gênero. O Vintila Horia, o Robbe Grillet, entre outros, que ele surpreende com tanta lucidez encantadora, em fase confessional a mais interessante, são revelações jamais apreendidas. E os pequenos fatos humanos, as figuras isoladas e os pequenos grupos, espécie da vibração humana no decorativismo urbano ou paisagístico, encantam-nos pelo descritivo tão rico de intencionalidade profundamente caracterizadora de Osman Lins, fazendo de seu livro de viagens uma obra de originalidade sugestiva. 
5. MOUTINHO, Nogueira. "Um marinheiro de primeira viagem”, Folha de S.Paulo, 27/10/1963 (IEB-USP) (consta no livro, parcialmente, a crítica de Moutinho).

Informação encontrada no arquivo do autor, pesquisado no IEB-USP. Caixa 1: Grupo Literatura. Tema: Marinheiro de primeira viagem. Notação: OL/LIT/MARINHEIRO/CX 1. Pasta 1/13.

Há turistas de todas as categorias, mas o pior espécimem é certamente o que se sente chamado a escrever o seu livro de viagem, o incoercivelmente impelido a violar a brancura do vazio papel e noticiar a eterna descoberta de monumentos que evidentemente durante séculos aguardaram a sua visita para serem revelados ao mundo. Esse é o pior turista: o turista que não quer ver a própria condição de indigência, que não se reconhece desaparelhado, desapercebido dos instrumentos e utensílios que fazem parte da bagagem daqueles que são os verdadeiros viajantes: Fernão Mendes Pinto na China, Stendhal na Itália, Ramalho Ortigão na Holanda, "Xavier de Maistre à roda do quarto, Garret na terra dele, Sterne na terra dos outros..." Ao lado uma meia dúzia digna de leitura na longa teoria de viajantes que da Renascença para cá têm contado aos que ficam, aos sedentários, as terras alheias. Há que ter o gênio do romancista para conseguir, não direi renovar o gênero, mas pelo menos não desonrálo, o que se dá ao trabalho de compor as suas memórias de viagem, porque se o relato não for tocado dessa atmosfera romanesca que os grandes viajantes lhe imprimiram é melhor traduzir os Guias Michélin. A Europa, sobretudo, é a grande vítima dos turistas de "sensibilidade à flor da pele": não há continente que mais desperte veleidades literárias na mediocridade ávida da gloriola. O resultado é essa massa enorme de relatos amornados, vulgares, requentados, sensaborões, que várias gerações de turistas têm acumulado.

Por esse motivo (e também, e sobretudo porque não lhe conhecia ainda o autor) recebi "Marinheiro de primeira viagem" (Editora Civilização Brasileira UM, Rio de Janeiro, 1963) de Osman Lins, com o desagradável receio de estar diante de "mais um" livro de viagem. Enganei-me, e fundo, porém. Não se trata de "mais um" livro de viagem; é antes "menos um" livro de viagens do que, não direi romance (talvez não chegue a tanto), mas quem sabe um gênero novo e original de relato: roteiro para um diretor de cinema inteligentíssimo, diário de escritor que escreve um romance, jornal de um personagem de romance... Mas é sobretudo um livro extraordinariamente civilizado, que só poderia ter sido escrito por um verdadeiro romancista. Osman Lins é um marinheiro de primeira viagem não apenas no sentido físico de ter ido à Europa pela primeira vez, mas no mais profundo de ver as coisas originalmente, com os olhos ungidos da pureza dos autênticos, da candura dos artistas, da viril abertura para todas 
as realidades, que deve ser a suprema saudade dos eruditos esterilizados. Ele é capaz de escrever páginas sobre Bruges, sem chamá-la uma só vez de "la morte", sem falar uma única vez em Rodenbach... Lembra-me muito na sua contida secura, no seu sóbrio desenho quase abstrato, lembra-me muito este relato o roteiro para um grande filme da "Nouvelle Vague", ou que nome lá tenham esses movimentos vanguardistas do cinema europeu, os quais procuram cada vez mais despojar-se de tudo que não é essencial em sua busca do "autêntico real absoluto". Que, como disse Novalis, é a essência da poesia.

Haveria que aproximar este livro também do "nouveau roman" cujos mestres (Butor e Robbe-Grillet) o autor visitou; mas o "nouveau roman" é-me ainda muito suspeito para que possa falar dele com isenção e sem reticências. Prefiro por isso aproximá-lo, confrontá-lo com o melhor cinema jovem europeu, embora saiba que o faço sem justificar-me. E há também outro nome que se não pode deixar de pronunciar, embora com a maior reverência: Proust. $\mathrm{Na}$ realidade, Osman Lins se entregou a uma "recherche du temps perdu" neste livro em que não há uma seqüência cronológica rígida, mas onde os relatos e as lembranças ocorrem e se agrupam ao vento da memória involuntária”. Osman Lins conseguiu atingir largamente seu propósito de "compor um livro de viagem que não se submeta à rotina do gênero aparentemente esgotado", onde nada recende ao bafio de museu ou de arquivo. É um escritor civilizado que prefere muitas vezes guardar de suas visitas a lembrança de um bando de meninos, de um encontro ou de um desencontro, do que o relato suspeito de suas emoções diante do túmulo de Napoleão. O que prevalece é a mobilidade da rua, do espetáculo gratuito, cidades vistas limpidamente por olhos jovens, paisagens, festas do povo, as obras de arte, os encontros no meio dos homens. É urgente a leitura deste livro que nos revela uma Europa desconhecida, a Europa dos marinheiros de primeira viagem. 
6. ROLME, Barbosa de. O Estado de S. Paulo, São Paulo, 07/12/1963 (sem título) (IEB-USP) (jornalista, crítico) (não consta do livro) (é esse o título? "Marinheiro de primeira viagem").

Informação encontrada no arquivo do autor, pesquisado no IEB-USP. Caixa 1: Grupo Literatura. Tema: Marinheiro de primeira viagem. Notação: OL/LIT/MARINHEIRO/CX 1. Pasta 1/12.

Em "Marinheiro de Primeira Viagem, Osman Lins realiza uma façanha: a de, sob certos aspectos, renovar entre nós a literatura de viagem. Em lugar de se ater às clássicas descrições das etapas do literário, seu livro - que tem por base países da Europa Ocidental desvenda-nos, ao mesmo tempo, visões de um país igualmente fabuloso: o da imaginação e da caça às sensações fugidias. O romancista de "O Visitante" sabe, é claro, evocar, numa sucessão de "flashes", a atmosfera peculiar de Paris, o encanto das tardes de Florença, o frenesi de uma corrida de touros em Pamplona... O aspecto mais marcante da obra reside, porém, na intensidade com que o autor pinta paisagens humanas. Sua apresentação da Piaf cantando no "Olímpia", seus encontros com Vintilla Horia ("Deus Nasceu no Exílio"), com Michel Butor (“A Modificação", "O Emprego do Tempo", etc.), com Barrault e outros, são expressivos depoimentos e convites à compreensão dessas personalidades, do que fizeram ou do que poderão fazer. Ao mesmo tempo, refletem o interesse do autor por tudo o que explique o fenômeno da presença do ser humano na terra. É claro, insistimos, que, mesmo sem fazer concessões aos clichês rotineiros, Osman Lins sabe transmitir suas impressões da França, da Bélgica, da Holanda, da Inglaterra, de Portugal, etc. Com muita habilidade fixa a emoção que, geralmente, sentimos ao descobrir, pela primeira vez, a silhueta da Torre Eiffel, os castanheiros dos Champs Elysées, a harmonia da colunata do Louvre, a serenidade da Ponte Vecchio e do Monte Palatino, o colorido dos canais holandeses ou o silêncio de Bruges. Mas se tais páginas nos falam à imaginação é porque o autor soube, ao mesmo tempo, captar o ritmo da hora que passa e dar vida ao sentimento imponderável que nos assola ao perceber a inutilidade da ânsia de prendermo-nos ao que é fugidio. Em certa passagem do livro (página 82) ele põe o dedo na chaga quando, referindo-se a si próprio, registra: "De repente, quando se aprestava para a viagem à Itália, viu o quanto era precário tudo o que constituíra, naqueles últimos dias, a sua vida. Seu passaporte era autêntico, sua situação regular. Mas ele, mesmo, era um clandestino num mundo que não lhe pertencia. Ali estava por uma concessão do destino, que lhe fazia presente de cidades e de relações humanas impossíveis. Tudo sem duração, veloz, esquivo; nada podia agarrar..." Nesse trecho está sintetizado o espírito do livro, que sendo de viagem no Velho Mundo é, também, o registro de viagem através a vida - 
a viagem em que todos estamos empenhados (Editora Civilização Brasileira. Capa de Eugenio Hirsch). 
7. RAMOS, Ricardo. "Paisagem interior de Osman Lins", O Estado de S. Paulo, São Paulo, s/d., no 420 (IEB-USP) (consta parcialmente no livro).

Informação encontrada no arquivo do autor, pesquisado no IEB-USP. Caixa 1: Grupo Literatura. Tema: Marinheiro de primeira viagem. Notação: OL/LIT/MARINHEIRO/CX 1. Pasta 1/11.

Anos atrás, escrevendo sobre um livro de evocações de infância, um crítico se viu em dificuldades. Enveredando pelo método comparativo, chegou a um beco sem saída: a obra não era memória nem crônica, não podia ser resolvida como romance ou contos encadeados, não se incluía em qualquer gênero definido - logo, não era nada. Felizmente, para autor e leitores, havia engano. O livro difícil de enquadrar-se resistiu vinte anos, teve reedições, é possível que subsista ainda mais tempo. Sem dúvida o ensaísta mais tarde reviu sua opinião inicial, com adjetivos copiosos.

Esses equívocos são freqüentes. E disso nos lembramos a propósito de um livro ainda novo, que tem muito para dificultar a catalogação apressada, subtrair-se àquela faixa que tranqüiliza e conduz o apreciador, pois não o força a interrogações e dúvidas que seria fraqueza deixar transparecer. Queremos nos referir a "Marinheiro de Primeira Viagem", de Osman Lins. Dizer o que o livro não é, além de pueril, viria repetir o velho erro crítico. Preferimos, ao contrário, alinhar o muito que nos oferece: um pouco de romance, de crônica, de reminiscência, alguma coisa de ensaio, momentos de poesia, disfarçados contos no apanhar de uma figura viva. Tudo isso, diga-se, a troco de uma viagem pelo estrangeiro. Então um livro de viagem!, exclamariam os amantes da generalização. Mais que isso, gostaríamos de destacar, um livro de Osman Lins. Porque em obras de tal natureza, assim contrárias ao titular mecânico, o escritor se sobrepuja à matéria sobre a qual escreve. E muitas vezes, liberto das limitações, pode mostrar-se na sua verdadeira estatura.

Que nos acostumamos a ver em livros de viagens? Normalmente o impressivo, o superficial, o cromático. Não raro o repórter, o anotador parcial. Há uma preocupação turística excessiva, há uma boa dose de compromisso político. Isso para não lembrarmos a inconveniência de julgar-se um país, um povo, com alguns dias de observação avulsa. Daí essa literatura ligeira, feita com intenção menor. O escritor brasileiro, na maioria, de certa forma se envergonha da sua condição, tende a esconder-se num populismo fingido, a evitar o que se possa avizinhar do erudito. Aspira a esse realismo feijão-com-arroz que imagina ao gosto do público, afastando todo esforço mental que resulte em pensamento expresso, afirmação mais clara. Atravessamos uma fase literária de exteriorizados, contemplativos, 
autores temerosos da aventura interior. E os livros de viagens, mais que quaisquer outros, frisam essa contradição que é de muitos. Com raras exceções, temos no gênero uma literatura visual, que informa, exclama e conclui, sem grandes movimentos de compreensão, sem nenhum traço de sentimento.

"Marinheiro de Primeira Viagem" é precisamente o contrário de tudo isso, não tem qualquer dos vícios que fazem a rotina dos nossos escritores viageiros. Osman Lins não se esconde, não fica pelo caminho em exclamações maravilhadas, não se sente obrigado a fornecer dados turísticos. As pessoas, as paisagens, os acidentes, tanto quanto as impressões, nos chegam filtrados pelo ângulo pessoal do autor. Ele quase não se preocupa em alinhar notas informativas, normalmente faz o inverso: deixa que tudo venha a transparecer em suas experiências, andanças, reações diversas. Isso, está claro, resulta em um livro afirmativo - não a simples declaração carente de esteios, em tom grandiloquente, mas a conclusão quase sempre razoável, lógica, pois baseada em reflexão e sentimento. Como entender sem sentir? Aqui não existe motivo para a indagação, os caminhos da compreensão passam pelo coração do escritor, nada se dissocia nesse corpo inteiriço. Vejamos, por exemplo, duas entrevistas: uma com Michel Butor, outra com Vintila Horia. O autor esperava muito do primeiro, pouco tinha em comum com o segundo. Ao correr das entrevistas, no entanto, os termos se inverteram. Butor é frieza, distância, o não mesclar-se no real. Horia é calor, procura, a participação. De pergunta em pergunta, mudamente discutindo frente aos dois romancistas, as opiniões que ouve Osman Lins vão fazendo os seus retratos bem nítidos e pode-se afinal concluir. O primeiro, imerso em jogos formais, afasta-se para dar lugar a uma cena viva em meio ao inverno. O segundo, com sua trepidação contagiante, resolve-se numa citação de aparência contraditória. Em ambos, o problema do artista diante do seu tema. Problema que se coloca, a cada página, diante do autor. E que empresta uma dimensão inesperada a esse livro severo, que tem muito de busca e soluções interiores, a fluir em seus fragmentos de ligeira paisagem e comparadas verdades.

Uma procissão em Bruges, cenas de rua, a figura da hoteleira ao despedir-se. As descrições fortes, com acentuado sentido plástico, ficariam bem num romance. Como os flagrantes, as personagens que saltam ou vibram isoladas, compondo tipos impressivos. Em Haia, o sobretudo perdido; em Lille o hotel, cheirando a resina com mel e flores murchas; em Verona, junto ao túmulo, a rosa de sol e Julieta revelada. As largas tomadas, mesmo as mais descritivas, são intelectivas e se misturam a lembranças, chegam ao interior e mostram um solitário no mundo. Os tipos têm uma carnação menos real que a dos postais, um pouco brumosa, um tanto desenho, mais semelham uma galeria de novela, de boa ficção. Entre eles 
avulta o narrador, verdadeiro nas opiniões, no que observa e transmite, mais próximo da personagem quando se põe a captar entrevistos momentos. Imprevistas sensações fugidias. Um homem sem as suas raízes, apenas ligado ao que vê pelo seu entendimento, pela sua emoção. No instante em Verona, diante da lápide, há uma volta às nascentes, ao chão brasileiro que ficou para trás, longe, bem longe, e nesse retorno se acha a tônica do livro, seu diapasão mais claro. $\mathrm{O}$ que importa na viagem é o que fala à sensibilidade, à experiência, à visão do autor, e assim intimamente assimilado se pode transfigurar e volver, com inteira ressonância, ao convívio dos leitores.

Um outro vezo dos que escrevem sobre livros, quase um preconceito da crítica, é o que leva à obrigatoriedade de se discordar, fazer reparos, mostrar-se não inteiramente afinado com o escritor. Isso, acreditamos, seria para afastar a imagem do principiante que elogia fácil. Mas aspirando à maturidade aparente, assim resvalamos no imaturo de sentido, caindo em pecado maior, o de não exercer o elementar da crítica: o exercício da compreensão. Dizemos isso para mais uma vez concordar com Osman Lins, chamando atenção para uma face importante do seu último livro - o diapasão, a coerência, o plano em que se desenvolvem as idéias, observações, os comentários. Sob a fluência que é marca do ficcionista, o sólido conteúdo que informa do escritor. Ele não faz concessões, não corteja nem se aligeira - mantém-se igualmente sério, equilibrado. E porque honesto, verdadeiro. Suas preocupações, onde quer que elas se situem, são as do intelectual, do observador atento e ponderado, de quem procura sempre um termo de razoável. Nunca do que finge, evitando o turbado momento de comoção, o natural espanto. Nunca do que se esconde, abrigando-se nas entrelinhas ou tiradas suspensivas. Tranqüilo, observando-se à medida que vai abarcando sua paisagem estrangeira, Osman Lins afirmativo se aprofunda em opiniões comedidas, transparentes, que vão formando um largo trecho de prosa adulta. Não a que estamos habituados a ler no gênero, repetimos. Bastante mais, bem maior, um plano muito mais elevado. Não fossem as raízes do autor, e que também aqui transparecem a marcar seu feitio agreste, poderíamos lembrar nesse livro uma boa tradução, de escritor que nos trouxesse de viagem uma lúcida bagagem civilizada.

Não seriam outras, aliás, as referências de Osman Lins escritor que a sua elaboração consciente, o seu exercício profissional, o seu evoluir lento e medido. De "O Visitante", ficou-nos a impressão de uma estréia excelente, a lançar um autor capaz de mover-se com personagens difíceis, interiorizadas, em linguagem habilmente transposta. Os contos de "Os Gestos", editados a seguir, pressupõem nos seus vários caminhos uma boa parte de experiência anterior, descortinando qualidades que mais tarde iriam afirmar plenamente, 
como ainda peças inteiriças, acabadas, de funda sensibilidade e raro apuro formal. Com "O Fiel e a Pedra”, finalmente, Osman Lins pode superar-se em arrojo temático e realização, dando-nos um romance que é dos bons momentos da nossa literatura atual. De resto, existem suas peças, existem seus contos publicados esparsamente, que também falam de uma constante intenção renovadora, de um não conformismo altamente produtivo e criador. Eis o escritor que nos deu, faz pouco, "Marinheiro de Primeira Viagem". Por isso quisemos frisar, logo de início, que esse livro se inscreve na bibliografia de Osman Lins. Não um lançamento marginal, não um acidente literário a esquecer-se. Mas um título apreciável, que se acrescenta a uma obra responsável e madura, de escritor que vem construindo laboriosa e severamente a sua permanência. 


\section{Anexo 4}

Crítica de Osman Lins sobre a exigência de depósito monetário para as viagens turísticas ao estrangeiro 
Isolamento Cultural $^{1}$

\section{Osman Lins}

O decreto, assinado há poucos dias, que exige um depósito prévio para as viagens ao exterior, tem provocado várias opiniões, dentre as quais a que apresenta, como alternativa, o chamado "turismo interno".

Essa opinião, ou sugestão, entretanto, merece alguns reparos, por falta de consistência. Ela procura dar a entender, talvez de caso pensado, que a viagem, seja para onde for, é apenas uma questão de tédio. Que o indivíduo viaja só e exclusivamente para não ficar em casa, para mudar de ares. E que pouco importa o lugar para onde vá, sendo necessário apenas que ele faça as malas e desapareça por alguns dias, só ou acompanhado.

Certamente, há pessoas para as quais a viagem é nada mais do que isso. Ouviram dizer que se deve viajar, e viajam. Poderiam, do mesmo modo, fazer qualquer coisa. Como tudo no mundo, viajar é um ato que pode ser desvirtuado. Todos conhecemos, por exemplo, indivíduos para os quais qualquer cidade do mundo, por mais rica que seja em tradições e monumentos, reduz-se ao quarteirão comercial, às lojas, às butiques: limitados e incultos que são, restringem-se a comprar. Ver e aprender, para eles, não tem sentido algum: as viagens, para essas pessoas, só se concretizam na medida em que podem encher as malas. Uma criatura assim, tanto faz ir a Londres ou Florença, como ir à Zona Franca, em Manaus, ou ao Paraguai.

Vale a pena, por isso mesmo, chamar a atenção para o sentido verdadeiro e superior das viagens. A não ser que se trate de um comerciante, não tem nenhum sentido viajar para comprar. Também, a não ser que se trate de um doente, não tem sentido viajar simplesmente para mudar de ares. E, em qualquer hipótese, não tem sentido viajar para ver o que se vê todos os dias.

Viaja-se - ou deve-se viajar, e, de qualquer modo, aí residem o valor e o significado das viagens - para ampliar os horizontes mentais. Desde logo, então, se vê que não é a mesma coisa viajar com destino a Maceió e ir a Paris; ou mesmo, conhecer Buenos Aires e conhecer Veneza. Claro que, segundo os interesses de cada indivíduo, variam os lugares cuja visita lhe será fecunda. Haverá alguns que serão mais enriquecidos, por exemplo, com uma viagem à Ásia ou à África, que com uma temporada nos Estados Unidos ou na Europa. Haverá aqueles cuja formação jamais será completa se não peregrinarem pelas velhas cidades européias.

\footnotetext{
${ }^{1}$ Osman Lins, Evangelho na taba: Outros problemas inculturais brasileiros, São Paulo: Summus Editorial, 1979.
} 
Como, sem dúvida, haverá os que necessitam de conhecer, se não todo o Brasil, pelo menos algumas regiões. Mas isto nascerá de uma predisposição interior, não de algum decreto que, dificultando-lhes a saída do país, obrigue-os a movimentar-se entre as nossas fronteiras: a fazer, em desespero de causa, o propalado "turismo interno".

Acho dispensável falar nesse turismo interno - sabidamente caro, sem conforto, sem respeito pelo viajante e com poucas atrações. Nele, só existem os hotéis, comedorias, uma ou outra paisagem interessante, poucos monumentos e (se a viagem for feita por via terrestre) estradas sem fim. Esse turismo, para quem não quer empanturrar-se de comida, ficar vendo televisão à noite nos quartos, fazer quilometragem nas rodovias e coisas assim, não vale nada. O herói vai e volta sabendo o que sempre soube: que o Brasil é grande. Quem sai da parte Sul, convence-se de que o Norte é mais pobre; quem vem do Norte, aprende (aprende?) que a parte Sul é mais rica. Escasso proveito. E não creio que seja preciso andar do Rio Grande do Sul para o Amazonas, ou do Maranhão para Santa Catarina, para amar o seu país. Se fosse assim, os maiores patriotas da nação seriam os caixeiros viajantes.

Permito-me, nessa ordem de idéias, uma confissão: foi após uma estada mais ou menos longa pela Europa, em 1961, que passei a ver e a compreender melhor o meu país. Esse distanciamento fez com que eu tivesse do Brasil uma idéia mais clara, mais nítida. Sentime, depois da viagem, mais ligado a ele, ao mesmo tempo que passava a enxergar com olhos novos as suas deficiências.

Isso, bem sei, foi uma experiência pessoal e não me animo a generalizá-la. Ela prova, em todo caso, que viajar para fora das fronteiras não é algo nocivo. Tanto podemos aproximar-nos do Brasil estando nele (nunca esquecerei minha viagem às velhas cidades de Minas Gerais), como longe dele.

Acho ainda que as viagens a lugares mais evoluídos e carregados de tradição, mesmo quando realizadas por pessoas um tanto medíocres, são necessárias ao nosso processo civilizatório. Tenho em mente, aqui, os países europeus, muitos dos quais, felizmente, conheço. Só quem viveu essa experiência pode saber o que ela significa. Visitar a Europa não é apenas sair de casa. Mergulhamos, ali, nas camadas mais profundas de civilização. Eis as grandes cidades históricas e artísticas. Eis as pequenas cidades muradas, os castelos, as igrejas dos primeiros séculos, as obras bizantinas, as catedrais góticas, as arenas. Isso não existe no turismo interno. Eis os infinitos museus, onde repousa, para edificar-nos, o que o homem tem guardado e conservado de sua longa aventura no mundo. Museus da arte egípcia, preciosidades da Assíria, da arte romana, da navegação, das porcelanas, da arte grega, dos relógios, da pré-história, da escrita, da China, da tapeçaria. (A desordem aqui, é intencional, 
quero expressar a fantástica riqueza de informações culturais com que se defronta o visitante nessa Europa cada vez mais distante, que se sugere substituir pelo turismo interno.) Também se encontra o que há de melhor e de mais importante na arte do nosso tempo.

Além disso, seja qual for a cidade em que esteja, o viajante nunca se vê obrigado, como nas cidades brasileiras, a passar as noites comendo; ou em boates quase sempre ordinárias; ou em frente a uma tela de tevê; ou, simplesmente, bestando. Todas oferecem espetáculos teatrais, balés, concertos. Todas. Isto para não falar em cidades como Paris, com seus 200 ( $\operatorname{sim}$, duzentos) filmes semanais e seus quase 100 ( $\mathrm{sim}$, quase cem) teatros a escolher.

Por outro lado, há o modo como as coisas funcionam. Os transportes que funcionam, sejam os de superfície, sejam os subterrâneos. Os hotéis baratos e que levam em conta, mesmo assim, a dignidade dos hóspedes. Os restaurantes populares onde se pode entrar sem uma triste sensação de penúria. Há o nível de vida, a qualidade de vida das pessoas, a assistência social. Há a contestação que funciona, sem que os países soçobrem. Há a imensa vida, a intensa vida cultural e política. Lá está em amplo mostruário, simultaneamente, do que o homem pôde construir no passado e do que está construindo em nosso tempo, em termos de arte, de técnica e de convivência. Nem todos podem ver isso, e, dos que podem ou puderam, nem todos colhem as mesmas lições. Mas algo fica, mesmo nos mais obtusos. E o que fica é uma aquisição para o país, aquisição sutil, mas importante e que não pode ser suprida em hipótese alguma por simples idas e vindas de um Estado a outro. Ou seja: pelo turismo interno. 


\section{Anexo 5}

Carta de Osman Lins à Companhia Melhoramentos de São Paulo, sobre a publicação de Marinheiro de primeira viagem 
Informação encontrada no arquivo do autor, pesquisado no IEB-USP. Caixa 1: Grupo Literatura. Tema: Marinheiro de primeira viagem. Notação: OL/LIT/MARINHEIRO/CX 1. Pasta 2/05.

São Paulo (SP), 20 de abril de 1977.

Ilm. O Sr.

Dr. Francisco Marins

Comp. Melhoramentos de São Paulo

Rua Tito, 479

CAPITAL

Prezado editor Francisco Marins,

Tomo a liberdade de encaminhar, para leitura, o MARINHEIRO DE PRIMEIRA VIAGEM, totalmente esgotado, razão pela qual não vai um exemplar do livro, e sim cópia "xérox".

Vem essa editora publicando apenas minhas obras de ficção, mas me parece que o MARINHEIRO, sendo um simples relato de viagem, movimentado, colorido, escrito com bastante leveza e boa dose de imaginação (eu diria mesmo de "ficção"), ficaria bem ao lado dos títulos mais ambiciosos, para os quais, visto ser um texto de fácil leitura, poderia servir de chamariz...

Acrescento - o que já foi dito, aliás, ao Sr. Décio Diêgoli - que o meu amigo Geraldo de Barros (atualmente com uma grande exposição individual no Museu de Arte Moderna) está disposto a ilustrar uma próxima edição do livro. Pelo interesse que teria nessa colaboração e também devido aos laços de amizade que nos unem, cobraria pelo trabalho, segundo me disse, o mínimo possível, de modo a não sobrecarregar o custo da edição.

$\mathrm{Na}$ expectativa se sua resposta, aqui fica o editado e amigo

\section{Osman Lins}

P.S. - Ando desaparecido. É que, há três semanas, fui submetido a uma intervenção cirúrgica e parece que a anestesia não foi bem aplicada. Em conseqüência, eu não podia ficar de pé: assaltavam-me dores muito fortes na nuca e que só agora começaram a amainar. O.L. 
Anexo 6

Notícias da viagem de Osman Lins à França na época em que ganhou a bolsa de estudos que o levaria a empreender a viagem relatada em Marinheiro de primeira viagem 
Informações encontradas no arquivo do autor, pesquisado no IEB-USP. Caixa 1: Grupo Literatura. Tema: Marinheiro de primeira viagem. Notação: OL/LIT/MARINHEIRO/CX 1. Pasta 2/06.

1. Diário da Noite-22/11/1960

\section{ESCRITOR PREMIADO}

O escritor Osman Lins acaba de ser premiado com uma bolsa de estudos nos principais centros culturais de França. Num concurso de composição francesa, promovido pela Associação Franco Cultural Brasileira, conquistou o primeiro lugar. 


\section{Osman Lins viajou (Não existe a fonte)}

Domingo passado, para a França. Pretende se dedicar a literatura e teatro, aproveitando a bolsa de estudos ganha em concurso na Associação Franco-Brasileira, durante seis meses. Depois, de retorno ao Brasil, é possível que fixe residência em São Paulo. 


\section{Diário de Pernambuco - 24/03/1961}

\section{Notícias de Paris}

O dramaturgo Osman Lins fala dos espetáculos da atual saison. Para que se tenha idéia de como aproveita a bolsa de estudos (foi estudar literatura teatral) transcrevo uma frase da carta que me enviou. "Minha ânsia de ver as coisas é tal, que já me sucedeu comprar dois bilhetes, para dois espetáculos diferentes a se realizarem na mesma hora". 